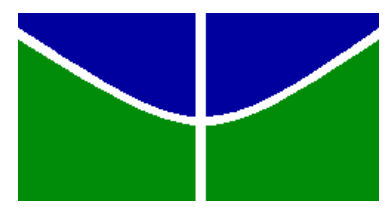

Universidade de Brasília - UnB

Faculdade de Economia Administração Contabilidade e Ciência da Informação e Documentação - FACE

Departamento de Ciência da Informação e Documentação - CID

DEMIAN ALVES PEREIRA

PAULO JOSÉ MEDEIROS MORAES

RECUPERAÇÃO DE INFORMAÇÃO JORNALÍSTICA AUDIOVISUAL UTILIZANDO LINGUAGEM DOCUMENTÁRIA:

ESTUDO DE CASO DA TV GLOBO BRASÍLIA 


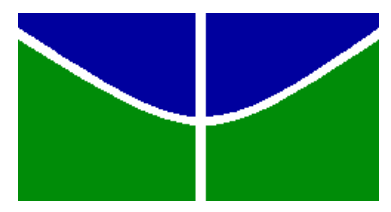

Universidade de Brasília - UnB

Faculdade de Economia Administração Contabilidade e Ciência da Informação e Documentação - FACE

Departamento de Ciência da Informação e Documentação - CID

\author{
DEMIAN ALVES PEREIRA
}

PAULO JOSÉ MEDEIROS MORAES

\title{
RECUPERAÇÃO DE INFORMAÇÃO JORNALÍSTICA AUDIOVISUAL UTILIZANDO LINGUAGEM DOCUMENTÁRIA: ESTUDO DE CASO DA TV GLOBO BRASÍLIA
}

\author{
Monografia apresentada ao Departamento \\ de Ciência da Informação e Documentação \\ como requisito parcial para obtenção do \\ grau de bacharel em Biblioteconomia.
}

Professora orientadora: Marisa Bräscher Basílio Medeiros 


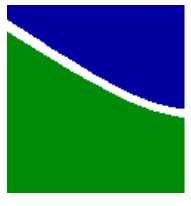

Universidade de Brasília

Campus Universitário Darcy Ribeiro - Asa Norte

CEP 70910-900

Brasília - DF - Brasil

Monografia apresentada ao Departamento de Ciência da Informação e Documentação, como requisito parcial para obtenção do grau de bacharel em Biblioteconomia

Brasília, 01 de julho de 2009.

Aprovada por:

Prof ${ }^{\mathrm{a}}$. Dr ${ }^{\mathrm{a}}$. Marisa Bräscher Basilio Medeiros

(CID/UnB) - Orientadora

Profa ${ }^{a}$. Mestre Ciência Política Íris Soares Lourenço Andrade Serafim (CID/UnB) - Membro

Prof ${ }^{\underline{a}} \mathrm{Dr}^{\mathrm{a}}$. Miriam Paula Manini

(CID/UnB) - Membro 
Dedicado a todos que vêem o resultado do nosso trabalho nos telejornais diários em todo o país. 
Agradecemos primeiramente a Deus por nos ter permitido chegar aqui;

Aos nossos pais, professores e colegas que nos ajudaram;

Às nossas supervisoras dos estágios por nos ter formado profissionais;

Aos funcionários do Cedoc da TV Globo Brasília pela paciência em esclarecer todas as dúvidas e perguntas;

Às nossas namoradas pela compreensão;

A todos que nos incentivaram a fazer um curso cujo nome ninguém consegue dizer.

Obrigado. 
"A vingança nunca é plena, mata a alma e a envenena"

(Ramón Valdez) 


\section{RESUMO}

Cita o surgimento da imprensa, a explosão informacional e o aparecimento das técnicas de recuperação e representação da informação. Discorre sobre o tesauro e suas principais funções, além de abordar a indexação de imagens em movimento, a qual pode ser feita por conteúdo e por conceitos. Situa e analisa as atividades de indexação de assuntos e imagens desenvolvidas no Centro de Documentação da TV Globo Brasília para atender às demandas da emissora. Descreve, exemplifica e ilustra os procedimentos de armazenamento, tratamento e recuperação das imagens. Contextualiza o trabalho do bibliotecário no desempenho destas atividades. Caracteriza as particularidades e necessidades da linguagem documentária utilizada no Cedoc, assim como suas qualidades e deficiências. Expõe os critérios de arquivamento, estrutura atual, recursos humanos, evolução dos recursos tecnológicos, divisão do acervo e suas classes. Mostra a política de indexação de assuntos gerais e esportes, a demanda por termos não existentes e a presença de termos desnecessários no tesauro. Expõe as confusões e curiosidades do trabalho de indexação e suas respectivas soluções. Mostra a demanda crescente de trabalho ao longo dos anos no Cedoc.

Palavras-chave: Indexação. Linguagem documentária. Tesauro. Recuperação da informação. Centro de documentação. Telejornalismo. Rede Globo. Informação audiovisual. Imagens. 


\begin{abstract}
It cites the press sprouting, the information explosion and the beginning of the recovery techniques and representation of information. It discourses about the thesaurus and its main functions. It approaches the movement images indexation that can be made by content and concepts. It points out and analyzes the indexation activities developed at the Documentation Center in Brasília Globo TV. Describes, give examples and illustrates the storage procedures, treating and images recovering. Shows the context of librarian in the performance of these activities. It characterizes the parcicularities and necessities of documentary language used in Cedoc, its qualities and needs. It displays the criteria of filling, current structure, human resources, evolution of the technological resources, collection division and its classification. It shows the indexation of general and sports subjects, the demand for not existing terms and the presence of unnecessary terms in the thesaurus. It displays the indexation work confusions and curiosities and their respectives solutions. It shows the increasing demando f work throughout the years in Cedoc.
\end{abstract}

Keywords: Indexation. Documentary language. Thesaurus. Information recovery. Documentation center. TV newscast. Globo TV. Audiovisual information. 


\section{LISTA DE ILUSTRAÇÕES}

Figura 1 - Representação documentária 18

Figura 2 - Centro de Documentação no Rio de Janeiro e robôs 24

Figura 3 - Centro de Documentação em Brasília 30

Figura 4 - Acervo de filmes $16 \mathrm{~mm} \quad 31$

Figura 5 - Amostra de filme $16 \mathrm{~mm}$ e projetor de filmes 32

Figura 6 - Acervo de fitas U-matic e exemplo de fita 33

Figura 7 - Acervo de fitas Betacam e exemplo de fita 34

Figura 8 - Acervo digital e exemplo de fita $\quad 35$

Figura 9 - Discos ópticos $\quad 35$

Figura 10 - Exemplo de gravação em caráter temporário 38

Figura 11 - Mapa do acervo de acordo com a tecnologia de vídeo 39

Figura 12 - Mapa do acervo de acordo com as classes 40

Figura 13 - Funcionários do Cedoc 43

Figura 14 - Exemplo de indexação $\quad 46$

Figura 15 - Exemplo de indexação contendo entrevista 48

Figura 16 - Amostra de termos iniciados pelo prefixo "estra" 59

Figura 17 - Exemplo de termo detalhado $\quad 60$

Figura 18 - Dois exemplos de entradas do Dicionário de Identidades 66

Figura 19 - Dois exemplos de casos de grande repercussão 66

Figura 20 - Exemplo de pedido feito ao Cedoc Brasília 68

Figura 21 - Pedido de imagens feito ao Cedoc 69

Figura 22 - Documento recuperado através da pesquisa livre $\quad 71$

Figura 23 - Resumo do procedimento de pesquisa de imagem $\quad 72$

Figura 24 - Lista de documentos recuperados $\quad 75$

Figura 25 - Relação entre matérias incluídas e indexações feitas $\quad 77$

Figura 26 - Pesquisa de itens (agosto de 2008 a março de 2009) 77

Figura 27 - Inclusão de documentos entre 2005 e 2008

Figura 28 - Pesquisas por item entre 2005 e 2008

Figura 29 - Demanda por área $\quad 79$ 


\section{LISTA DE TABELAS}

Tabela 1 - Exemplos de dúvidas durante a indexação

Tabela 2 - Excesso de informação causando ambiguidade

Tabela 3 - Exemplos de termos pouco utilizados

Tabela 4 - Exemplos de termos que não constam no Thesaurus 


\section{SUMÁRIO}

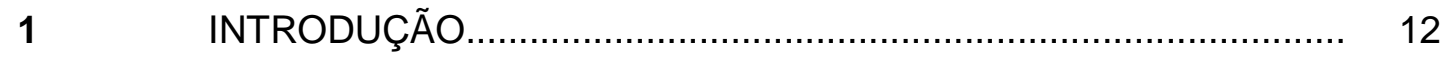

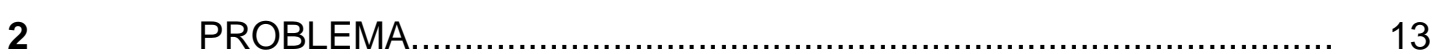

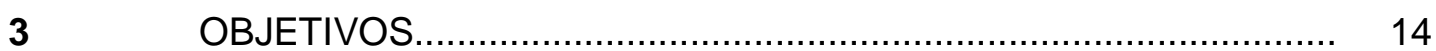

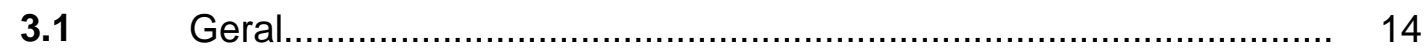

3.2 Específicos........................................................................... 14

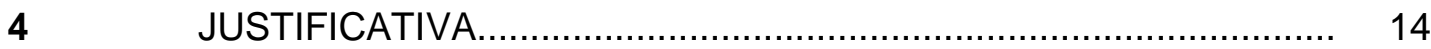

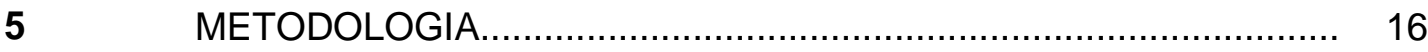

$6 \quad$ LINGUAGEM DOCUMENTÁRIA ........................................... 17

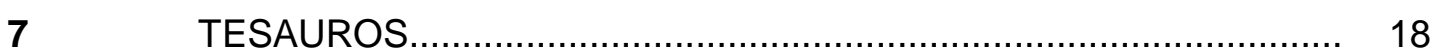

$8 \quad$ INDEXAÇÃO DE IMAGENS EM MOVIMENTO

$9 \quad$ INFORMAÇÃO JORNALÍSTICA ................................................ 22

10 O CENTRO DE DOCUMENTAÇÃO ............................................... 23

11 A CENTRAL GLOBO DE COMUNICAÇÃO - CGCOM................... 26

$12 \quad$ O CEDOC E A CGCOM........................................................ 27

Parte 3 - O Cedoc Brasília

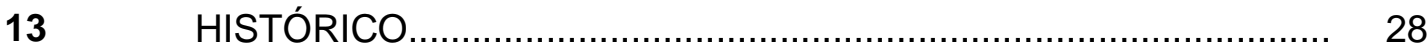

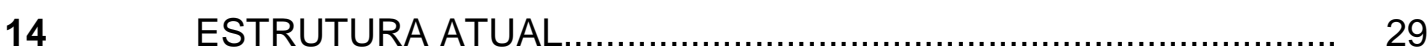

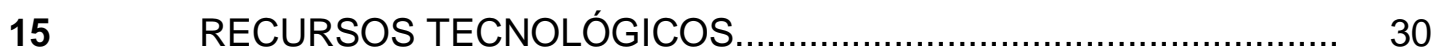

$15.1 \quad$ Filme

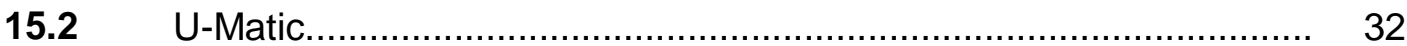

$15.3 \quad$ Betacam .............................................................................. 33

$15.4 \quad$ O formato MPEG IMX ........................................................... 34

$15.5 \quad$ Disco óptico em XDCAM........................................................ 35

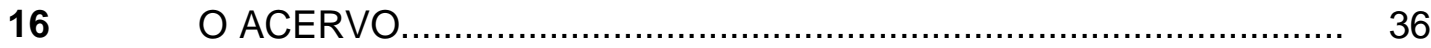

16.1 A divisão do acervo.......................................................... 37

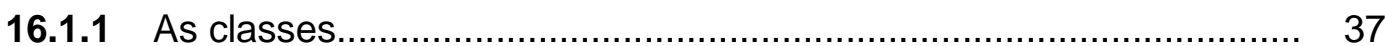

16.1.2 O material temporário................................................................ 38

16.1.3 Agenda cultural.......................................................................... 39

$17 \quad$ O CEDOC E OUTRAS EMISSORAS ....................................... 40

17.1 Material cedido para outras emissoras......................................... 40

17.2 Material adquirido de outras emissoras.......................................... 41

18 O PROCESSO DE ARQUIVAMENTO .......................................... 41

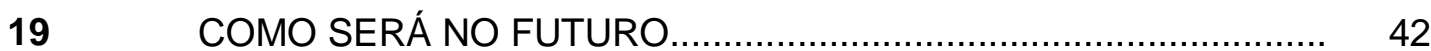


RECURSOS HUMANOS ........................................................ 42

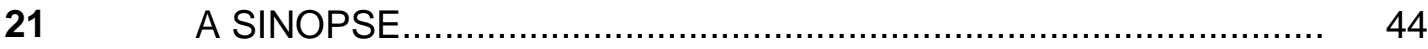

22 O PROCESSO DE INDEXAÇÃO............................................. 45

22.1 Política de indexação de assuntos gerais..................................... 49

22.1.1 Local............................................................................... 50

22.1.2 Entrevistas......................................................................... 50

22.1.3 Acidentes naturais............................................................ 50

22.1.4 Viagens oficiais..................................................................... 51

22.1.5 Escândalos................................................................................ 52

22.1.6 Assassinato e morte................................................................... 52

22.1.7 Manifestação................................................................................ 53

22.1.8 Economia........................................................................... 53

22.1.9 Outras orientações................................................................... 54

22.2 Política de indexação para esportes............................................. 54

23 AS DIFICULDADES E CASOS CURIOSOS ................................... 55

24 A LINGUAGEM DOCUMENTÁRIA ........................................ 59

$24.1 \quad$ O Thesaurus........................................................................... 59

24.1.1 Termos com baixa demanda....................................................... 61

24.1.2 Deficiência de termos................................................................. 62

24.1.3 Outros casos............................................................................ 64

24.1.4 Sugestões e critérios............................................................. 64

24.2 O dicionário de identidades....................................................... 65

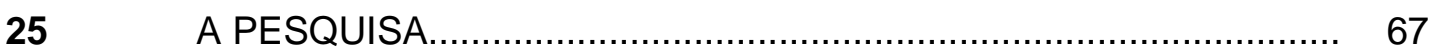

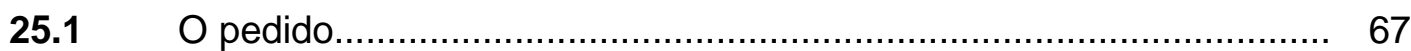

25.2 Pesquisa controlada e pesquisa livre............................................. 70

$25.3 \quad$ O procedimento resumido......................................................... 71

25.4 Pontos fortes e pontos fracos do sistema...................................... 72

$25.5 \quad$ Precisão e revocação........................................................................ 73

$26 \quad$ ESTATÍSTICAS................................................................ 76

27 A VIDEOTECA GLOBAL................................................... 80

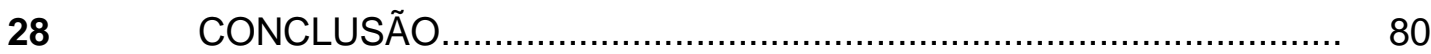

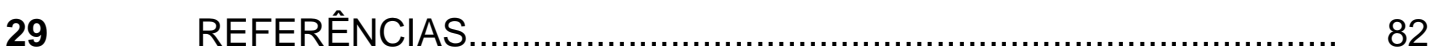

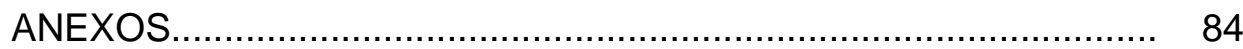




\section{INTRODUÇÃO}

O surgimento da imprensa, entre os séculos $X V$ e $X V I$, causou um grande impacto nos centros informacionais da época, pois, antes desse acontecimento, os sistemas de informação procuravam adquirir tudo o que se produzira até então, como a famosa Biblioteca de Alexandria, como exposto por Campelo (2006). É válido lembrar que houve várias tentativas de se obter o controle de toda a bibliografia que era produzida, como o caso de Conrad Gesner, que, antes da invenção da imprensa, possuía um grande acervo em várias línguas e áreas do conhecimento.

A grande "explosão informacional", principalmente no aspecto cientifico, deuse após a Segunda Guerra Mundial e com o surgimento da Guerra Fria. Neste momento se observou um grande incentivo às pesquisas científicas nos países já totalmente industrializados, sendo necessários estudos que visassem à representação e recuperação da informação.

Essa primeira mudança de paradigma no âmbito da organização e disponibilizaçao do conhecimento produzem discussões sobre as técnicas de análise documentária vigentes. Se no passado, a leitura que se podia fazer dos documentos (representação genérica) não atendia mais às necessidades de especificidade dos temas produzidos pela comunidade científica, era necessário o desenvolvimento de instrumentos que, ainda no plano de representação de conteúdos, dessem conta do ultra-especializado. (DODEBEI, 2002, p.11)

Neste contexto, a gestão documental torna-se aspecto de fundamental importância para o mundo, pois, diante da grande quantidade de documentos, se faz necessária a recuperação da informação com maior precisão.

Hoje há uma preocupação quanto à necessidade de se preservar a informação para acessá-la. Em todas as atividades do dia-a-dia, as pessoas querem ter acesso à informação por diversos motivos. Para ser acessada, a informação precisa estar organizada, isto é, disposta de forma a poder ser recuperada. Assim, os bibliotecários, entre outros profissionais envolvidos neste processo, tornam-se responsáveis pela preservação e disseminação de um patrimônio de valor inimaginável: a informação. 


\section{PROBLEMA}

O volume crescente de informações produzidas pela mídia, mais especificamente pelas empresas jornalísticas, sejam elas jornais impressos, rádios, Internet ou emissoras de televisão, faz com que seja necessário se pensar em técnicas para seu tratamento e armazenamento, de modo que se possa viabilizar sua posterior recuperação. No entanto, esbarra-se em diversas dificuldades, tanto no aspecto financeiro quanto na falta de planejamento e qualificação de profissionais que lidam com a informação todos os dias.

Um estudo empírico poderá contribuir para o entendimento das questões relacionadas à organização e recuperação da informação jornalística. Este estudo será realizado com base em observações e relatos vividos na prática em uma empresa do ramo jornalístico que possua um setor específico para organização das informações produzidas.

O objeto de estudo em questão é o Centro de Documentação (Cedoc) da TV Globo Brasília, que utiliza um sistema automatizado de armazenamento, indexação e recuperação de imagens que torna possível a execução dos trabalhos desenvolvidos na empresa com eficiência.

Para tentar atender às necessidades da emissora, foi criado o Cedoc, que se constitui num setor onde são desenvolvidas atividades relacionadas predominantemente ao jornalismo, embora esteja subordinado à Central Globo de Comunicação (CGCom), órgão que se relaciona com o público externo. No Cedoc se arquiva todo o material produzido pela emissora.

Entre os diversos aspectos a serem analisados a respeito da rotina do Cedoc, observa-se dificuldades durante o trabalho de indexação em situações que exigem termos que até então não constavam no tesauro desenvolvido pela equipe. Como exemplo, entre muitos que serão expostos durante o desenvolvimento do estudo, pode-se citar a falta do termo "licitação", assunto de interesse que quase sempre é citado nos noticiários quando o assunto é a administração pública. Por outro lado, depara-se com termos constantes no tesauro que se supõe de baixa utilização, por exemplo, espécies de aves que nunca apareceram nos noticiários ou grupos religiosos inexpressivos. 


\section{OBJETIVOS}

\subsection{Geral}

Analisar as atividades de indexação e recuperação de imagens em movimento desenvolvidas no Centro de Documentação (Cedoc) da Rede Globo de Brasília, visando a contribuir para um melhor atendimento às demandas da emissora.

\subsection{Específicos}

- Descrever os procedimentos de armazenamento, tratamento e recuperação de informações jornalísticas em formato audiovisual;

- Identificar e contextualizar o trabalho do bibliotecário no desempenho destas atividades;

- Relatar os recursos tecnológicos disponíveis no Cedoc da Rede Globo em Brasília;

- Caracterizar as particularidades e necessidades da linguagem documentária utilizada no Cedoc, assim como seus pontos fortes e fracos;

- Sugerir critérios de atualização (inclusão e exclusão) de termos nas linguagens documentárias.

\section{JUSTIFICATIVA}

O trabalho desenvolvido por bibliotecários em um centro de documentação de uma emissora de televisão ainda é pouco conhecido. Portanto, torna-se necessário realizar um estudo que busque responder a questões básicas, tais como: o que faz um bibliotecário numa emissora de TV; como é feito o tratamento do enorme volume de informação produzida pelos telejornais todos os dias; quais são as técnicas utilizadas, os profissionais envolvidos, as dificuldades encontradas, etc. 
Ao longo dos anos, os centros de documentação de jornais e televisão foram adquirindo importância vital dentro das organizações, fato que os levou a um constante processo de automação. Essa importância pode ser tanto histórica, quando se refere aos fatos e notícias que são veiculados, ou até mesmo organizacional, no que se refere à própria história da empresa à qual o centro de documentação pertence.

O bibliotecário que está inserido nesse meio deve acompanhar a evolução do papel do jornalismo e de sua respectiva produção. Ele não deve desprezar esse campo de trabalho em expansão em que ainda há grande carência de profissionais qualificados. Ele possui know-how, ou seja, conhecimentos e técnicas para desempenhar com desenvoltura sua função no setor quaternário, o da informação.

Para que ele alcance tal estágio e se lance no campo do jornalismo com seu ritmo frenético de produção de informação, é necessária uma mudança de mentalidade, que implica num alargamento de horizontes, de fronteiras, abandonando a idéia de que sua área de atuação se restringe aos limites físicos da biblioteca, podendo, sim, atuar em emissoras de televisão.

Em relação ao trabalho desenvolvido pelos bibliotecários nas emissoras de TV, é importante citar o fato de ser mais fácil preparar um bibliotecário para trabalhar com informações jornalísticas do que um jornalista ser transformado em "bibliotecário" de um centro de documentação. Enquanto o bibliotecário recebeu formação adequada para tratar e manipular tipos variados de informação, incluindo as jornalísticas, o jornalista às vezes se mostra resistente ao uso de técnicas biblioteconômicas, além de ser resistente ao trabalho dentro de um centro de documentação, quando ele na verdade preferiria atuar em edição, produção ou reportagens externas, sua área mais comum de atuação.

Por ser um centro de documentação relativamente recente (a estrutura atual do Cedoc foi implantada em 1996), ainda não foram feitos estudos acadêmicos sobre seu funcionamento, serviços oferecidos, perfil dos profissionais, necessidades e problemas encontrados. Neste sentido, a unidade de informação em questão foi escolhida para o presente estudo por ser esta uma situação inédita cujo resultado poderá inclusive servir como instrumento de divulgação de uma modalidade de 
trabalho que ainda é pouco conhecida entre os estudantes de Biblioteconomia e, às vezes, pelos próprios bibliotecários.

\section{METODOLOGIA}

O presente trabalho foi dividido em três partes: na primeira, buscou-se fazer uma abordagem de modo a fornecer embasamento teórico sobre a linguagem documentária, indexação, tesauros e informação jornalística. Esbarrou-se na pouca quantidade de material disponível a respeito da informação jornalística. Foram feitas pesquisas em livros, diversos artigos de periódicos, monografias, dissertações de mestrado, teses de doutorado e sites da emissora que foi objeto de estudo.

Na segunda parte, buscou-se contextualizar o Centro de Documentação da emissora. O Cedoc está subordinado à Central Globo de Comunicação (CGCom), respondendo por suas ações, desempenho e relatando quaisquer acontecimentos ou necessidades. Baseado na Teoria Geral de Sistemas, teríamos três órgãos a serem avaliados: o maior, a Rede Globo como um todo; o intermediário, a CGCom, à qual o Cedoc está vinculado; e por fim, o Cedoc, considerado o sistema específico, já que é o tema central deste trabalho.

A terceira parte é a fase em que é realizado um estudo de caso sobre o Cedoc Brasília: sua estrutura, recursos, rotinas, técnicas, o trabalho desenvolvido, etc. Diante da inexistência de literatura e/ou trabalhos anteriores sobre o objeto de estudo em questão, todo o trabalho foi feito com base na observação direta, questionários aplicados à equipe de profissionais do Cedoc, entrevista com pesquisadores e editores, bem como a própria experiência do trabalho.

Dados de desempenho foram colhidos do relatório mensal das atividades no Cedoc e compilados, de modo a inferir quanto às necessidades e demandas atuais de trabalho. Um questionário foi aplicado à pesquisadora-chefe do Cedoc, no qual foram abordados temas gerenciais e técnicos. Outro questionário foi enviado aos demais funcionários que trabalham na edição de imagens, pesquisas, elaboração de sinopses e à bibliotecária. 


\section{PARTE 1 - FUNDAMENTAÇÃO TEÓRICA}

\section{LINGUAGEM DOCUMENTÁRIA}

Para auxiliar no processo de recuperação da informação, as linguagens documentárias surgiram no contexto do grande crescimento informacional como uma das soluções que faz o intermédio entre o usuário e a informação. Segundo Lancaster (2004), é uma linguagem artificial que representa o assunto de um documento. É válido lembrar do grande desafio que o indexador percorre até chegar à tradução final do conteúdo, pois é preciso que a linguagem documentária atenda ao mesmo tempo as necessidades do indexador para representar o assunto, a "aceitação" do sistema (vocabulário controlado) e a busca dos usuários no sistema informacional. $O$ indexador deve expressar o assunto sem que seu sentido seja alterado.

Existem alguns tipos de linguagens documentárias: as notacionais ou verbais e as pré-coordenadas ou pós-coordenadas. As notacionais, como o nome sugere, utiliza notações, ou seja, símbolos para organizar catálogos e fazer a localização de documentos nas estantes. Como exemplos temos a Classificação Decimal de Dewey $^{1}$ e a Classificação Decimal Universal², que utilizam números. As verbais têm seu foco na representação de assuntos para recuperar a informação, tendo como exemplo os tesauros. As pré-coordenadas possuem uma ordem antes dos usuários fazerem sua busca; elas são coordenadas segundo seus princípios classificatórios, como, por exemplo, uma ordem alfabética; já as que possuem pós-coordenação são ordenadas após a busca do usuário e permitem aos termos buscados se correlacionarem, sendo eles de assuntos aproximados. Nos índices póscoordenados, os termos atribuídos aos documentos representam uma rede de relações, segundo Lancaster (2004). O vocabulário controlado nada mais é que uma relação de termos autorizados.

\footnotetext{
1 CDD, ou "Decimal Classification",surgiu como uma classificação voltada para organização de bibliotecas, dividiu o conhecimento humano em dez classes.

2 CDU, Criada pelos belgas Paul Otlet e Henri La Fontaine, se basearam em Dewey. É uma linguagem de indexação e de recuperação do conhecimento registrado na qual cada assunto é simbolizado por um código baseado nos números arábicos.
} 
Uma síntese da representação documentária foi feita por Dodebei (2002), na Figura 1, com algumas modificações; ela faz uma síntese da representação documentária.

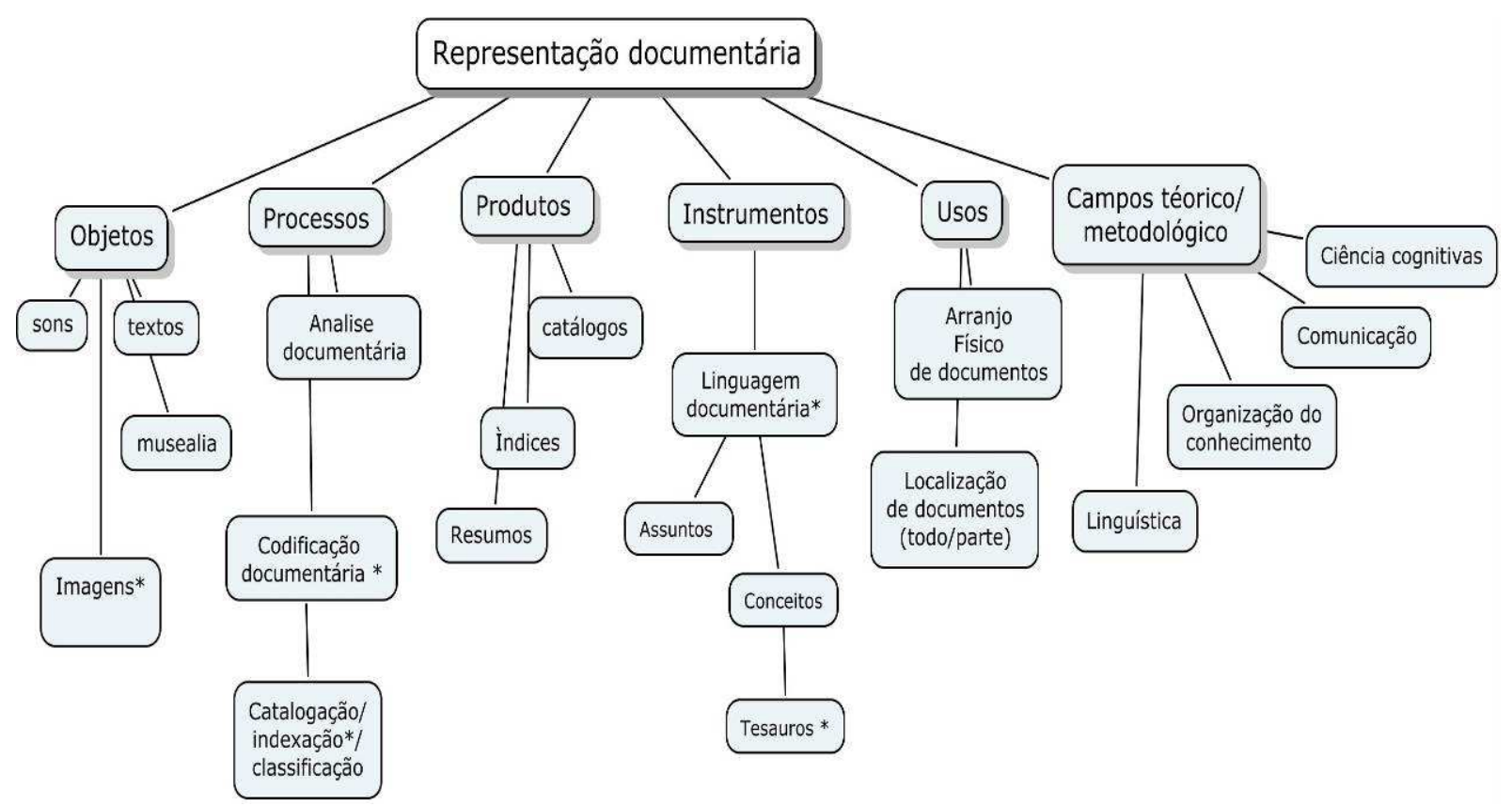

Figura 1: Representação documentária - Dodebei (2002)

\section{TESAUROS}

A origem da palavra tesauro vem da Grécia antiga e remete à palavra "tesouro", significando armazenagem ou enciclopédia, como afirma Dodebei (2002). Sem dúvida, os tesauros são considerados um dos principais mecanismos de representação de conteúdo, onde é feita a seleção de palavras, onde as idéias são melhor representadas. Dodebei (2002) ainda afirma que Tesauro é "um instrumento capaz de transportar conceitos e suas relações mútuas". O fato deste instrumento possibilitar relações entre os termos é o seu grande diferencial; possibilita ao pesquisador da informação relacionar assuntos que a priori não possuem relação alguma, ou pesquisar assuntos relacionados. 
Uma característica das mais importantes no tesauro é o fato dele ser lógico. Isso ajuda tanto quem vai construir este instrumento quanto quem vai pesquisá-lo; os relacionamentos são feitos de forma lógica e hierárquica.

Lancaster (2004) aborda dois princípios fundamentais na seleção de termos para a construção de um tesauro e que serão fundamentais como critérios que usaremos para avaliar o sistema de recuperação do Centro de Documentação da Rede Globo de Televisão. São eles: exaustividade na seleção dos termos, que parte da política de indexação da instituição em questão, onde quanto mais termos forem elaborados para representar aquele documento mais acessível ele estará. $\mathrm{Na}$ exaustividade da indexação é preciso tomar cuidado para não trazer à tona idéias falsas do conteúdo. O segundo principio trata da especificidade. Segundo Lancanster (2004), este é o princípio mais importante na indexação de assuntos, onde uma idéia deve ser indexada com sua especificidade máxima, em que é necessário se ter cuidado para não cair no erro da redundância.

Outra característica marcante do tesauro é o controle terminológico. $\mathrm{Na}$ construção de um vocabulário controlado, é de extrema importância a terminologia selecionada, pois ela deve atender os conteúdos que irão fazer parte daquele tesauro e a necessidade ou o entendimento dos usuários no que diz respeito ao conteúdo. Nesta característica, dois aspectos devem ser analisados para que se avalie aquele sistema de recuperação de informação (SRI): a revocação, ou seja, a quantidade de vezes que o termo é buscado; e a precisão, no que diz respeito à terminologia utilizada, segundo Lancaster (2004). Podemos dizer que a revocação é considerada a relação entre o número de itens ou documentos recuperados pelo SRI e o número total de itens existentes naquela base de dados, ou seja, é a capacidade de recuperar documentos úteis ao usuário. A precisão é medida pela relação entre o número de documentos relevantes recuperados e o número total de documentos recuperados.

Atualmente outra questão é colocada nos SRI: a tecnologia, aparato imprescindível nos SRls. Ela oferece novos desafios, como a mediação entre sistema e usuário, mas também é a solução de várias interligações entre os termos que compõem o tesauro e possibilita relações entre SRIs, que antigamente era inimaginável. 


\section{INDEXAÇÃO DE IMAGENS EM MOVIMENTO}

Lancaster (2004) afirma que a indexação tem como seu principal objetivo a representação temática dos documentos, ou seja, indicar do que trata o documento e resumir seu conteúdo.

Miranda (2007) trata a indexação de imagens focada em duas abordagens principais: a primeira conhecida como indexação baseada no conteúdo e a segunda seria uma indexação baseada em conceitos. A primeira abordagem é formada por buscadores algoritmos, ou seja, baseada nas funções computacionais. São as características técnicas das imagens como cor, textura e formato. A segunda abordagem é sobre a qual vamos nos ater. É a representação das imagens por palavras-chave, possuindo toda uma complexidade, pois ela não é puramente lógica, pois o seu resultado é formado pela opinião do indexador.

O autor citado deixa claro que estes dois focos da indexação não se opõem, mas se complementam. Sobre a indexação baseada em conceitos, é válido lembrar que existem técnicas que são propostas e geralmente empregadas na seleção de descritores que pertencem a um vocabulário controlado que vão descrever os documentos, não sendo diferente nas imagens em movimento.

Johanna Smit (1996) aborda aspectos interessantes para serem analisados quando está sendo realizada a indexação de imagens, que podem ser absolutamente utilizáveis em qualquer tipo de analise documentária: segundo a autora, as categorias QUEM, ONDE, QUANDO e COMO/O QUÊ, utilizadas por muitos estudiosos como parâmetro para a análise de textos, inclusive a documentária, é também preconizada para a análise documentária de imagem. QUEM seria a identificação do ser enfocado, ONDE é o local em que a imagem foi gerada, QUANDO é o tempo, ou seja, o ano, mês ou dia e COMO/O QUE aborda o assunto da imagem.

O telejornalismo ganhou novo impulso com o registro de informação baseado nas imagens em movimento, que dinamiza e fornece energia a este novo formato de jornalismo, onde a palavra está vinculada à imagem. Ao mesmo tempo em que a palavra ganha um novo brilho com a imagem, é inegável o poder expressivo que a imagem por si mesma possui. A partir deste "poder" das imagens, Gonçalves (2005) 
propõe que, mais que selecionar palavras-chaves na busca de arquivos de imagens em movimento, é necessário a detecção de "imagens-chaves", onde o ponto de referência são as imagens. Aristóteles, em sua célebre frase, sacramenta: "não pode haver uma única palavra sem imagem".

Neste contexto de novas tecnologias e sistemas de recuperação voltados para as lógicas computacionais, os metadados ganham grande valor no desenvolvimento da indexação de imagens em movimento. Eles podem e devem padronizar a linguagem de representação, principalmente na indexação voltada aos conteúdos, que, como dito anteriormente, é parte que complementa a indexação baseada em conceitos.

A indexação de imagens tem sido objeto de estudo de vários pesquisadores. O nosso grande desafio é o de que não estudaremos apenas imagens em si, mas imagens em movimento como: matérias jornalísticas, entrevistas e às vezes apenas gravações de imagens brutas que posteriormente serão inseridas em jornais televisionados.

Estes serviços de indexação possuem um SRI, que, por sua vez, possuem técnicas de compreensão e análise de conteúdos. É válido lembrar que o processamento de imagens em SRIs tem como objetivo "permitir maior visibilidade por parte dos usuários e prepará-las para serem avaliadas no que se refere às suas próprias características" (GONÇALVES, 2005. p.66).

A indexação possui duas etapas expostas por Lancaster (2004). A primeira é a chamada análise conceitual, onde o indexador define do que se trata o documento. A partir daí é necessário que o indexador entenda quais são os usuários desse Sistema de Informação e suas necessidade primordiais. A segunda etapa é a chamada tradução, onde é feita a escolha dos termos que representarão os assuntos de determinado documento. Lancaster (2004, p. 15) afirma que "tradução envolve uma decisão sobre quais os rótulos disponíveis que melhor representam x, y e z". Esta segunda etapa, sem dúvida, é uma das principais em todo o processo de indexação, pois elas são "as portas" dos documentos. Se os termos forem mal escolhidos, isso pode significar o "falecimento" de um documento. 
No contexto de imagens em movimento, também há as duas etapas da indexação. Elas apenas passam por uma adaptação necessária à mídia que é utilizada. A respeito deste fato, discorreremos de forma mais clara e detalhada no decorrer do estudo.

\section{INFORMAÇÃO JORNALÍSTICA}

O jornal é um produto que se faz a cada dia e todos os dias, como afirma Rozados (1997). Sua matéria-prima, segundo a autora, é a informação, especialmente a informação nova que é acrescentada, na maioria das vezes, às já existentes. Ao se falar em jornalismo, primeiramente nos vêm à mente os telejornais, pois a televisão, com sua combinação de sons e imagens, cativam-nos e é capaz de prender nossa atenção por horas. Paternostro apud Gonçalves (2003) afirma que "É com a imagem que a televisão compete com o rádio e o jornal, exercendo o seu fascínio para prender a atenção das pessoas". O autor ainda faz uma distinção entre os diversos veículos de comunicação em massa e a TV. Esta apresenta um caráter especial, o fato de dispor do código icônico (imagem) como suporte básico de sua linguagem. Os programas jornalísticos, às vezes, concedem prioridade excessiva a este elemento visual. Lobo (1990) ressalta a importância da imagem em movimento como fator de identidade sócio-cultural e fonte de informação. Esta importância da imagem em movimento foi consolidada pelo desenvolvimento do cinema e o incremento da produção e consumo do vídeo.

Andrade (2003) afirma ter havido uma revolução no jornalismo, com as novas tecnologias da informação e comunicação. Assim, versões eletrônicas de quase todos os grandes jornais do mundo foram criadas para se manterem atualizados nesse contexto do surgimento de um novo veículo de comunicação que reúne características de todas as outras mídias: a Internet, que revolucionou e continua exercendo seu fascínio sobre as pessoas, consolidando-se assim uma nova era da informação, apesar de ainda estar acessível a uma minoria. Além de não apresentar limitações de espaço como os jornais e revistas em formato convencional, a Internet possibilita a recuperação de informações com maior facilidade e agilidade.

Em relação à sua assimilação, devemos notar que a informação 
representa um processo de interação entre o sujeito e uma determinada estrutura de informação, que gera uma modificação em suas condições mentais, através de sua competência cognitiva produzindo conhecimento, que se relaciona corretamente com a informação recebida. A assimilação da informação é o agente mediador entre a informação e o conhecimento. É um estágio qualitativamente superior ao uso da informação. (BARRETO apud GONÇALVES, 2003)

Ainda de acordo com Barreto apud Gonçalves (2003), a informação pode ser qualificada "como um instrumento modificador da consciência do homem e de seu grupo". Assim, a informação passa a ser instrumento gerador de conhecimento, uma vez que o conhecimento "só se realiza se a informação é percebida e aceita como tal, colocando o indivíduo em estágio melhor de convivência consigo mesmo e dentro do mundo onde sua história individual se desenrola" (idem, p. 59).

A informação também pode ser considerada

o sangue da ciência. Sem informação, a ciência não pode se desenvolver e viver. Sem a informação a pesquisa seria inútil e não existiria conhecimento. Fluido precioso, continuamente produzido e renovado, a informação só interessa se circula, e, sobretudo, se circula livremente. (LE COADIC, 1996)

\section{PARTE 2 - CONTEXTUALIZAÇÃO}

\section{O CENTRO DE DOCUMENTAÇÃO}

O arquivo de mídia da TV Globo, denominado Cedoc (Centro de Documentação) é responsável pela preservação do acervo da emissora. No prédio climatizado da sede no Rio de Janeiro estão guardados os documentos, contando com dois robôs para agilizar a recuperação. Os robôs são articulados e deslizam sobre trilhos, podendo alcançar 11 metros de altura e 40 metros de profundidade. $O$ pesquisador insere o número do documento a ser buscado e os robôs realizam a busca no acervo com exatidão. O prédio possui ainda capacidade para abrigar 350 mil fitas. Por mês, pelo menos 80 mil delas entram e saem do acervo. No Cedoc ainda é feita a reutilização de cerca de $70 \%$ das fitas, gerando economia de mais de $\mathrm{R} \$ 5,6$ milhões por ano, segundo informações disponíveis no site da emissora. 


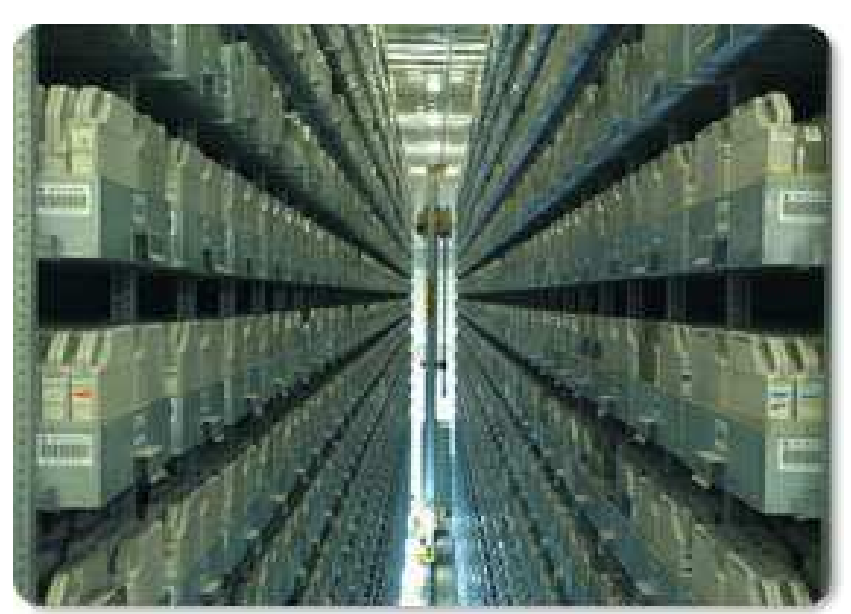

Figura 2: Centro de documentação no Rio de Janeiro e robôs. Fonte: Rede Globo.

O Cedoc atende a diversos setores da TV Globo: jornalismo, engenharia, arte, programação, etc. São arquivados materiais dos mais diversos formatos, tais como: livros, periódicos, fotográficos, slides e claro, imagens em vídeo e filmes.

Diferentes termos são empregados para denominar esses materiais: materiais audiovisuais, meios audiovisuais, materiais não-impressos, materiais não-gráficos, materiais não-bibliográficos, mídias, médias e multimeios. (AMARAL, 1987)

Figueira (1989) aponta para a necessidade de um centro de documentação de rede de televisão, antes de tudo, ser versátil e dinâmico. Para isso é necessário que o sistema através do qual o acervo é organizado também o seja. O principal objetivo de um centro de documentação, segundo Gonçalves (2003), é poder separar, fácil e eficientemente, documentos de um arquivo que sejam relevantes para uma determinada necessidade do usuário. Isto requer um esquema de indexação com significado. Rozados (1997) afirma que a credibilidade e a atualidade do jornal são asseguradas pela agilidade e eficiência de seu banco de informações. Ainda de acordo com a autora, ao usar uma tecnologia avançada, seus diversos sistemas, tais como processamento, armazenamento, controle e recuperação da informação permitem gerenciar as bases de dados e material informacional em formatos diversos, como texto e imagem.

O setor responsável por isto está em constante mudança. As previsões de crescimento, tanto de ingresso de novas informações em formato de texto ou imagem, quanto de buscas, são sempre superadas, o que obriga seus profissionais 
a frequentes reavaliações e reciclagens sobre os sistemas e métodos de controle, armazenamento e recuperação. Novas tecnologias adotadas pelas emissoras afetam o desempenho dos bancos de dados e geram novas necessidades de informação.

O crescimento da informação, sua disseminação cada vez mais veloz no contexto atual, a falta de controle terminológico e a necessidade cada vez maior em estruturar um setor de pesquisa, incluindo a indexação das matérias jornalísticas produzidas pelos meios de comunicação, levaram à criação de unidades de informação, com diferentes denominações: centros de documentação, bancos de dados, setor de pesquisa, entre outros.

A necessidade dos bancos de dados estarem sempre atualizados no que diz respeito às novas tecnologias, às alterações estruturais e de processos é ressaltada por Rozados (1997). A maneira do grupo trabalhar é que determina as necessidades de adaptação de seu formato. Também de grande importância, é preciso ser levado em consideração que os leitores de um jornal ou telespectadores de uma rede de televisão são os clientes potenciais e usuários de seus bancos de dados, ainda que de forma indireta. O maior problema apontado por Gonçalves (2003) no que diz respeito à indexação e recuperação de um conteúdo de imagem é a determinação de características que possam fornecer uma performance satisfatória na sua classificação para uma posterior recuperação de forma adequada.

Como alguém encontra uma foto em um arquivo contendo milhões de fotografias? Como um jornalista encontra uma imagem contida em uma matéria específica entre uma infinidade de matérias produzidas diariamente pelas emissoras de TV que incluem uma enorme diversidade de temas que vão do noticiário local e nacional ao internacional, ao comportamento, esporte e às matérias sobre assuntos, simplesmente, indicados pelos indexadores como "gerais"? Ainda segundo Turner "é como encontrar uma agulha no palheiro. O problema é que o palheiro não para de crescer e o jornalista encontra cada vez mais dificuldades para encontrar a agulha ou a imagem desejada. Some-se a isso, a questão do tempo. É preciso encontrar a agulha no palheiro rapidamente". (Entrevista com, TURNER, J. apud GONÇALVES, 2003, p. 160).

O Centro de Documentação da Rede Globo tem se tornado uma peça de importância fundamental dentro da emissora, devido à qualidade dos serviços prestados. Todo o material existente antes da implantação do CDRG foi incorporado 
pouco a pouco e anexado ao acervo. A saída encontrada para a automação e integração dos Cedocs das praças foi a migração para um computador de grande porte (mainframe) e o desenvolvimento do sistema em micro-computador para atender as emissoras de pequeno porte. Toda a estrutura que funciona no CedocRio é a mesma que deve ser usada nas praças, com exceção do dicionário de identidades, que será exposto mais adiante.

\section{A CENTRAL GLOBO DE COMUNICAÇÃO - CGCOM}

Apesar do trabalho do Centro de Documentação estar relacionado predominantemente às atividades do jornalismo, o Cedoc não está subordinado à Central Globo de Jornalismo (CGJ), e sim à Central Globo de Comunicação (CGCom). As principais áreas nas quais está dividida a Rede Globo são:

CGAL - Central Globo de Afiliadas e Licenciamento;

CGCom - Central Globo de Comunicação;

CGCQ - Central Globo de Controle de Qualidade;

CGE - Central Globo de Engenharia;

CGIAP - Central Globo de Informática, Administração e Planejamento;

CGJ - Central Globo de Jornalismo;

CGP - Central Globo de Produção;

CGPG - Central Globo de Programação;

CGPRH - Central Globo de Pesquisa e Recursos Humanos;

DGC - Direção Geral de Comercialização.

DOF - Central Globo de Operações Financeiras;

As relações institucionais e a imagem da Rede Globo junto ao público são apenas parte da função da Central Globo de Comunicação. Com os setores de Relações Externas, Divisão de Propaganda, Projetos Sociais, Cedoc, entre outros, sua atuação vai da maioria das ações externas da companhia às ações sociais, passa pelo apoio ao trabalho de criação e pelo lançamento de novos produtos.

Sobre as ações sociais desenvolvidas pela CGCom, destacam-se três: Ação Global, que é um mutirão de lazer, esporte, atendimento médico, emissão de documentos, mini-cursos e outros serviços de cidadania em geral; Criança 
Esperança, conhecido projeto em parceria com a Unesco que visa a arrecadar fundos para ajudar dezenas de instituições e projetos sociais espalhados pelo país; Amigos da Escola, que tem o objetivo de contribuir para o fortalecimento da escola pública de educação básica, estimulando o envolvimento de profissionais da educação, alunos, familiares e comunidade no desenvolvimento de ações educacionais.

\section{O CEDOC E A CGCOM}

O Cedoc é visto pela emissora com departamento patrimonial, pois no local é preservado todo o material produzido pelo jornalismo. Na visão da emissora, quem cuida do patrimônio, do nome da empresa, das ações beneficentes, do relacionamento empresa-público, do visual (vinhetas, aberturas de novela), da marca Globo, dos comerciais institucionais, de tudo que diz respeito diretamente ao valor patrimonial da emissora é direcionado à Central Globo de Comunicação e o Cedoc entra nesta classificação. A visão pode ser considerada equivocada, já que o acervo não é voltado para o público externo. $O$ trabalho predominante é armazenar e atender ao público interno nas suas necessidades: o jornalismo.

O papel de atendimento às necessidades também pode ser estendido ao público externo em menor escala. Existe um serviço de atendimento através da videoteca às instituições educacionais ou associações de classe nas suas necessidades quanto à utilização de vídeos em sala de aula. Hoje o atendimento aos telespectadores que solicitam documentos (matérias e/ou programas) para diversas finalidades é feito através de uma empresa terceirizada (Conteúdo Expresso), com sede em São Paulo. A Conteúdo Expresso é uma empresa especializada em licenciamento de conteúdos produzidos por diferentes meios de comunicação. Entre os principais, estão: a TV Globo, a revista Carta Capital, a Editora Abril e o doutor Dráuzio Varella, entre outros. $O$ atendimento prestado pelo Cedoc também auxilia os demais departamentos da emissora (comercial, programação, etc.) no que for preciso e na medida do possível para fornecer material em termos de vídeo e informação. A ferramenta de trabalho do Cedoc é 
informação jornalística e ela deve estar disponível para quem quer que seja dentro do seu universo de atendimento e limitações impostas pela emissora.

\section{PARTE 3 - O CEDOC BRASÍLIA}

\section{HISTÓRICO}

A história do Cedoc inicia com a própria história da TV Globo Brasília. Na época de sua criação, em abril de 1971, todo o material era produzido em filme (película) e sempre houve a necessidade de guardar a produção. Então os filmes eram numerados, guardados em caixas e o assunto de cada filme era datilografado em fichas, que eram guardadas em um fichário por ordem alfabética, por assunto.

Este procedimento durou até o ano de 1979, quando vieram os primeiros cassetes profissionais: os U-matic (veremos diversos materiais mais adiante). O que foi feito neste período foi um grande desastre em termos de arquivo, pois apenas eram feitas fichas contendo datas e retrancas (nome da matéria). Em cada fita havia uma ficha com uma descrição mínima (escrita à mão) do que estava guardado nela. Assim, o Cedoc tornou-se completamente ineficiente. Tudo era guardado, mas ninguém conseguia encontrar o que procurava. Muitas vezes só se podia contar com a memória dos arquivistas ou de alguém mais atento do jornalismo. Era necessário saber quando tal fato aconteceu e a partir daí buscar a fita com a data e tentar localizar as imagens ou matéria que estava sendo requisitada. Como ninguém encontrava algo e o trabalho de pesquisa era manual, tudo era pedido para a Globo Rio ou refeito em Brasília.

Diante da situação, o Cedoc foi fechado em 1987. A partir de então, as fitas de arquivo eram montadas com o material editado e simplesmente guardadas sem que houvesse algum cuidado ou qualquer tipo de tratamento das informações. $O$ que havia era um verdadeiro depósito de fitas amontoadas, num ambiente cheio de poeira, goteiras no telhado, mofo, etc. Depois de alguns anos, constatou-se que eram documentos em vídeo se deteriorando cada vez mais. 
O fato foi relatado a alguns chefes da época e finalmente foi feita a recuperação do telhado. Depois disso, uma equipe do Cedoc Rio veio a Brasília para fazer um levantamento das necessidades e possibilidades para montagem de um novo Cedoc. Após dois anos de muita negociação, foi construído um pequeno prédio, mas que acomodaria, além do novo Cedoc, outros departamentos da emissora. Um ano depois, o prédio estaria pronto.

Após várias negociações com todos os diretores envolvidos, inclusive com o próprio Roberto Marinho, presidente das Organizações Globo, iniciou-se um novo trabalho aos mesmos moldes do Cedoc do Rio de Janeiro, em 3 de maio de 1996, tendo Denise Alves de Castro como supervisora, a idealizadora do Cedoc e atualmente pesquisadora chefe. Há bastante volume de trabalho, cujas etapas serão expostas detalhadamente no decorrer do estudo. O Cedoc tem se mostrado eficiente e atendido a praticamente todas as demandas apresentadas. $O$ trabalho desenvolvido é necessário e indispensável para a atividade jornalística da emissora.

\section{ESTRUTURA ATUAL}

Hoje o Centro de Documentação está situado no edifício sede da emissora, no Setor de Rádio e TV Norte. O Cedoc ocupa uma área de $81 \mathrm{~m}^{2}$, dos quais $32 \mathrm{~m}^{2}$ são destinados ao acervo. Há três ilhas de edição, onde é feita a maior parte do trabalho.

A ilha 1 conta com recursos de gravação da programação, cópia e edição de VTs, pesquisa e cópia de imagem, conversão entre os diversos formatos, além de suporte para todos os materiais disponíveis no Cedoc (filme, U-matic, betacam, fita digital, VHS e DVD). A ilha 2 conta com recursos de edição e montagem de VTs, gravação da programação, suporte para DVD, VHS, decupagem e suporte para fitas em formato betacam. A ilha 3 possui apenas suporte para decupagem de material em betacam. Por decupagem se entende o processo de registrar no banco de dados as características do documento audiovisual arquivado, seus dados técnicos, sinopse e outros dados que possam facilitar sua recuperação posterior. É a fase que antecede a indexação, a qual será detalhada mais adiante. 
Além das ilhas, há um computador utilizado apenas para se fazer o recorte de jornais locais em formato digital para disponibilizá-los no servidor da emissora de modo a facilitar sua consulta. Este recurso foi implantado recentemente e o material é disponível apenas na intranet. O público externo, o telespectador comum, tem acesso aos telejornais pela Internet (www.g1.com.br/dftv), mas apenas vídeos selecionados pelo editor da web.

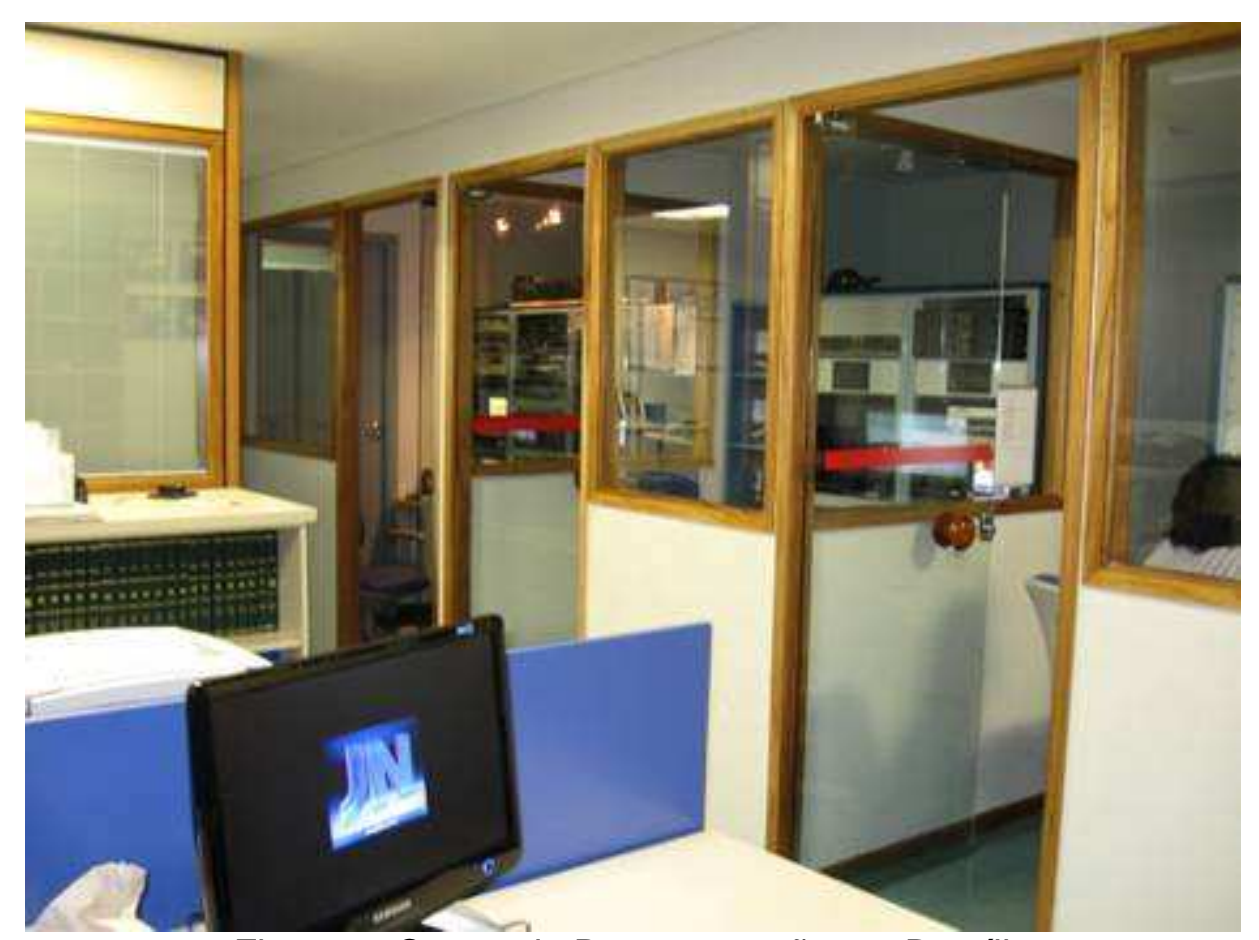

Figura 3: Centro de Documentação em Brasília

\section{RECURSOS TECNOLÓGICOS}

Nos últimos anos houve uma evolução tecnológica nos formatos de mídia utilizados na produção de vídeo. A TV Globo acompanhou as mudanças e, ao se olhar para o acervo do Cedoc da emissora, pode-se perceber a história desta evolução.

\subsection{FILME}

Na época da implantação do Cedoc Brasília (1971), o material utilizado era o filme (ou película). O filme é um material fotográfico feito à base de celulóide, 
fabricado em formato de lâmina translúcida. Quando aplicada com determinados produtos químicos, a película é utilizada para cinema. Há diversos formatos de filmes, em geral definidos pela sua bitola, ou seja, sua largura. Os utilizados na TV Globo foram os de $16 \mathrm{~mm}$ e boa parte do acervo está neste formato. Este recurso foi utilizado durante toda a década de 1970, até a popularização dos vídeos nos anos 1980, dando início a uma nova era tecnológica.

Hoje há um projetor de filme no Cedoc, mas, devido a um defeito técnico e à falta de peças para reposição, foi necessário que o setor de Engenharia da emissora desenvolvesse um mecanismo alternativo em que se adaptou uma câmera filmadora para, simplificando, "filmar o filme" e fazer sua conversão para o formato atual. Depois de copiado para outro formato e feita sua devida decupagem, o filme em questão é inutilizado. Os dados inseridos no sistema durante o processo de decupagem estarão disponíveis para toda a rede e as imagens ficarão de modo bem mais acessível para sua posterior recuperação. Desta forma, o material produzido durante os anos 1970 aos poucos está sendo transferido para o formato atual e suas informações inseridas no banco de dados, o que não existia na época de sua criação.

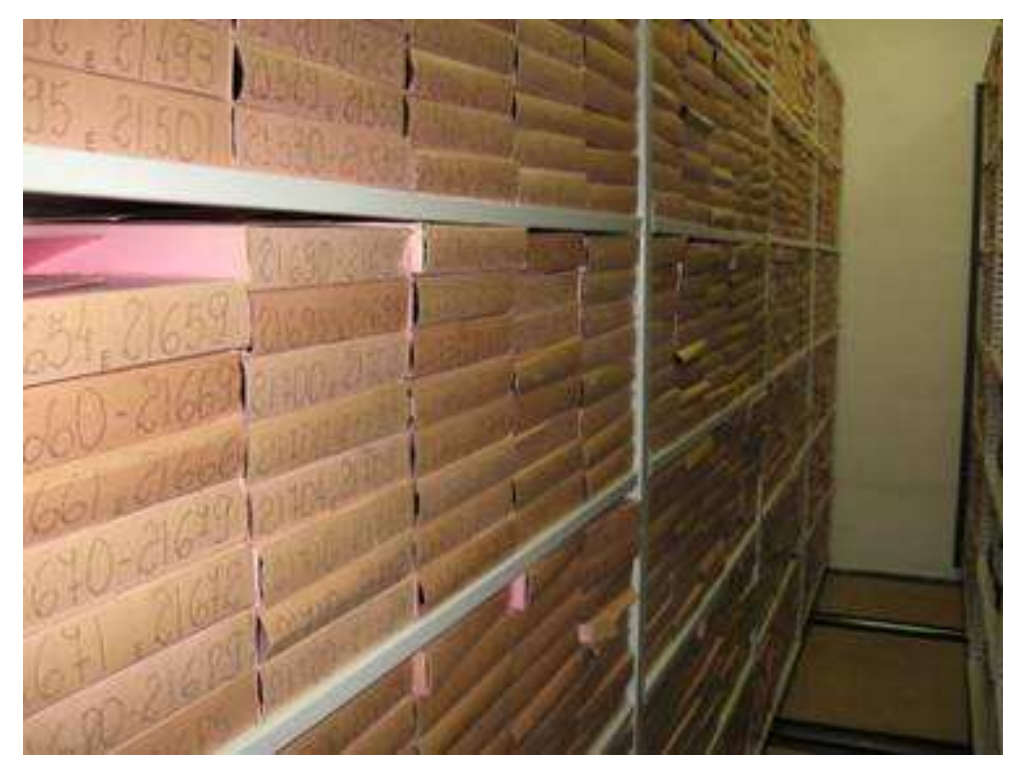

Figura 4: Acervo de filmes $16 \mathrm{~mm}$ 


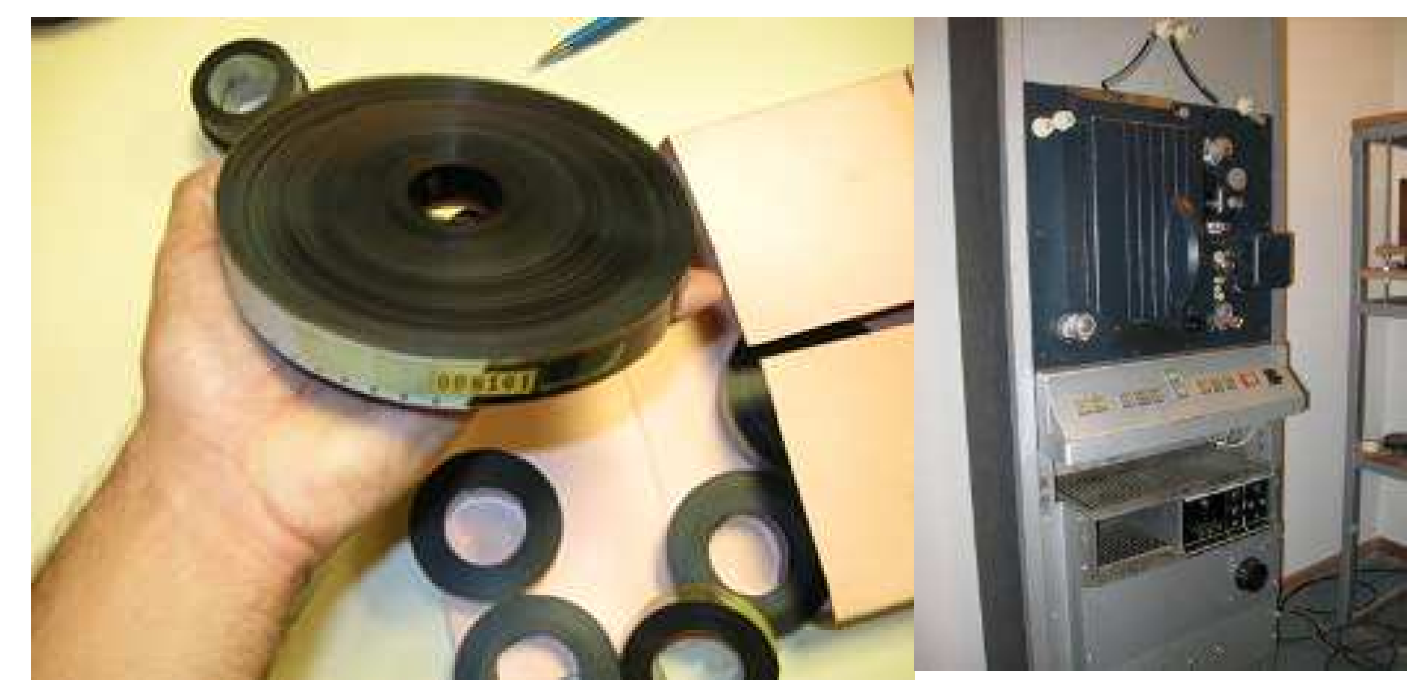

Figura 5: Amostra de filme $16 \mathrm{~mm}$ e projetor de filmes

\subsection{U-MATIC}

U-matic é um formato analógico de fita desenvolvido ainda na década de 1970 para uso profissional e possuía características técnicas tão avançadas para a época que permitiam sua edição de forma facilitada. O formato permite maior precisão nas imagens devido ao fato das dimensões da fita e outros componentes do equipamento utilizado serem maiores que as usadas anteriormente, proporcionando maior estabilidade nas imagens.

O U-matic utiliza fita de $3 / 4$ polegada e foi o primeiro formato utilizado largamente com fita ao invés de carretéis. Uma versão melhorada deste formato, com maior resolução de cor, foi lançada alguns anos mais tarde.

A TV Globo utilizou este formato durante os anos 1980. O acervo de U-matic possui mais de 2300 horas de gravação de matérias entre brutas e editadas. É nesta parte do acervo que está contido material jornalístico de importância histórica para o país, tais como: a campanha das Diretas (1984), a primeira eleição presidencial direta após o regime militar (1989), os sucessivos planos econômicos e mudanças de moeda, entre outros temas nacionais e regionais.

Como o sistema de recuperação do Cedoc foi implantado apenas em 1996, este material, assim como boa parte dos filmes, não está inserido no banco de dados, ou seja, não foi decupado. Alguns temas relevantes, como os citados, já 
foram decupados, pois costumam ser bastante solicitados. O restante está sendo inserido aos poucos.

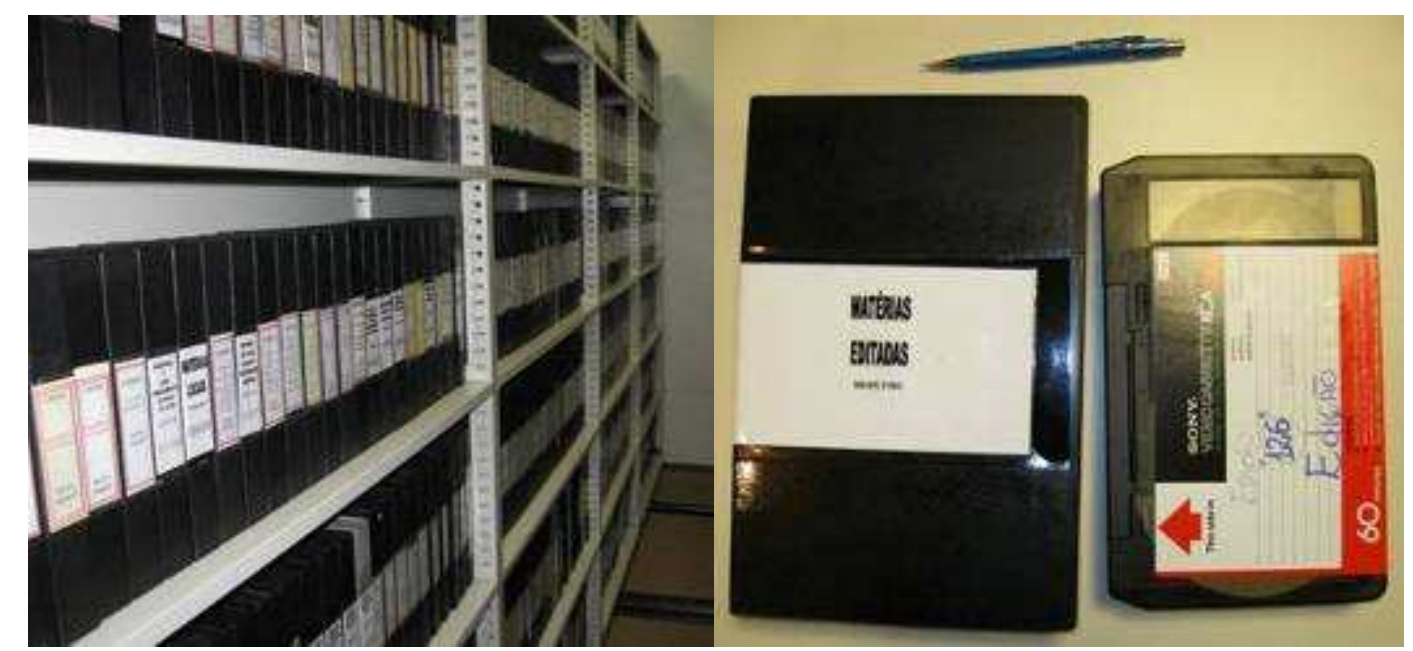

Figura 6: Acervo de fitas U-matic e exemplo de fita

\subsection{BETACAM}

O formato analógico Betamax foi o primeiro desenvolvido para o segmento consumidor. Com a competição do formato VHS, o Betamax foi perdendo força no mercado devido ao custo mais baixo do VHS e sua maior capacidade de gravação.

Outro formato analógico bastante utilizado é o Betacam. Criado pela Sony no início dos anos 1980, utiliza fita de $1 / 2$ polegada e é similar ao seu antecessor, o Betamax, mas com velocidade de deslocamento de fita 6 vezes maior.

A TV Globo utiliza o formato Betacam desde 1991, quando este substituiu o U-matic. Hoje esta tecnologia já está em fase de substituição. Assim como ocorre com o U-matic, grande parte do material de importância histórica para o país, criado antes da implantação do sistema de recuperação do Cedoc já se encontra decupado. Isto significa que temas como o Impeachment do ex-presidente Collor (1992), os escândalos da política (anões do orçamento em 1993, por exemplo), criação do Real (1994), dentre outros temas relevantes, já estão inseridos no sistema, pois são bastante solicitados e sua decupagem antecipada facilita sua recuperação.

Aos poucos, o resto do material está sendo decupado, mas se esbarra na falta de profissionais, já que a demanda crescente de trabalho não permite que haja tempo para isto. 


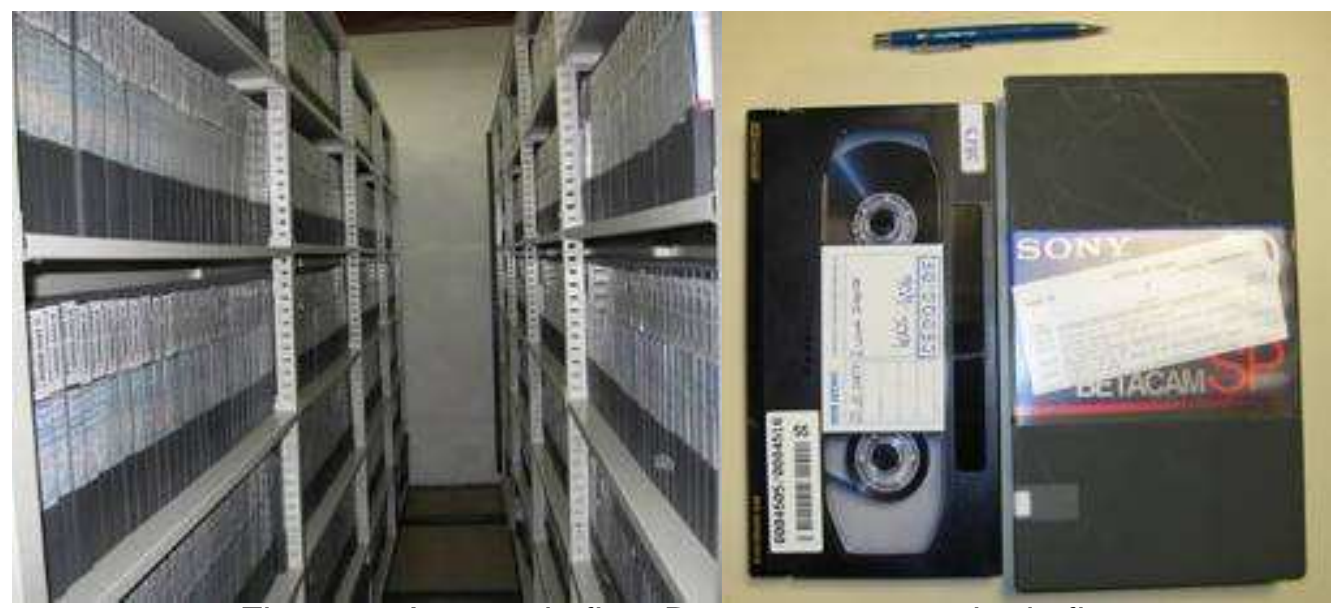

Figura 7: Acervo de fitas Betacam e exemplo de fita

\subsection{O FORMATO MPEG IMX}

Esta é uma evolução da família de formatos Betacam existentes. Trata-se de um formato digital profissional criado pela Sony em 2001. A gravação pode ser feita em fita de $1 / 2$ polegada ou diretamente em HD (hard disk) em alguns modelos de videocassetes especiais. O vídeo é comprimido em alta qualidade de imagem e pode ser gravado em diferentes configurações conforme a qualidade desejada

O acervo do Cedoc possui um espaço reservado para este material, mas as fitas pertencem não pertencem ao Cedoc, mas ao departamento de jornalismo. Nada está decupado e as fitas estão provisoriamente no Cedoc por falta de espaço. As fitas contêm principalmente depoimentos em CPIs (Comissões Parlamentares de Inquérito) dos Correios, dos bingos e depoimentos no Conselho de Ética da Câmara dos Deputados. 


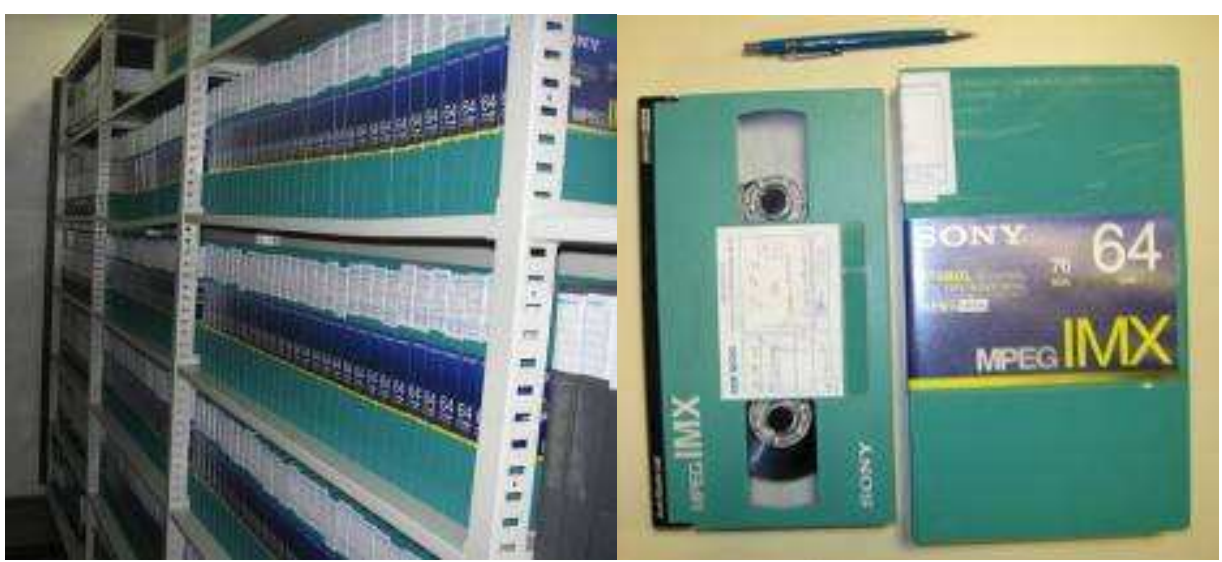

Figura 8: Acervo digital e exemplo de fita

\subsection{DISCO ÓPTICO EM XDCAM}

XDCAM não é propriamente um formato, e sim um sistema de armazenamento de dados de vídeo, criado em 2004. As imagens são armazenadas em formato digital, ou seja, em linguagem binária ( 0 e 1). É utilizado pelo segmento profissional e há várias subdivisões deste sistema, o qual não será detalhado por não ser o foco deste estudo. Os dados de imagens são gravados em disco óptico.

A TV globo está passando por uma reformulação tecnológica. Este é o estágio mais atual. A emissora adotará esta tecnologia a partir de janeiro de 2010 e não trabalhará mais com fitas. O material utilizado será o disco óptico. O Cedoc manterá o passado em fitas, que serão utilizadas neste formato por vários anos, porque copiar todo o material para o novo sistema demanda muito tempo e custos financeiros.

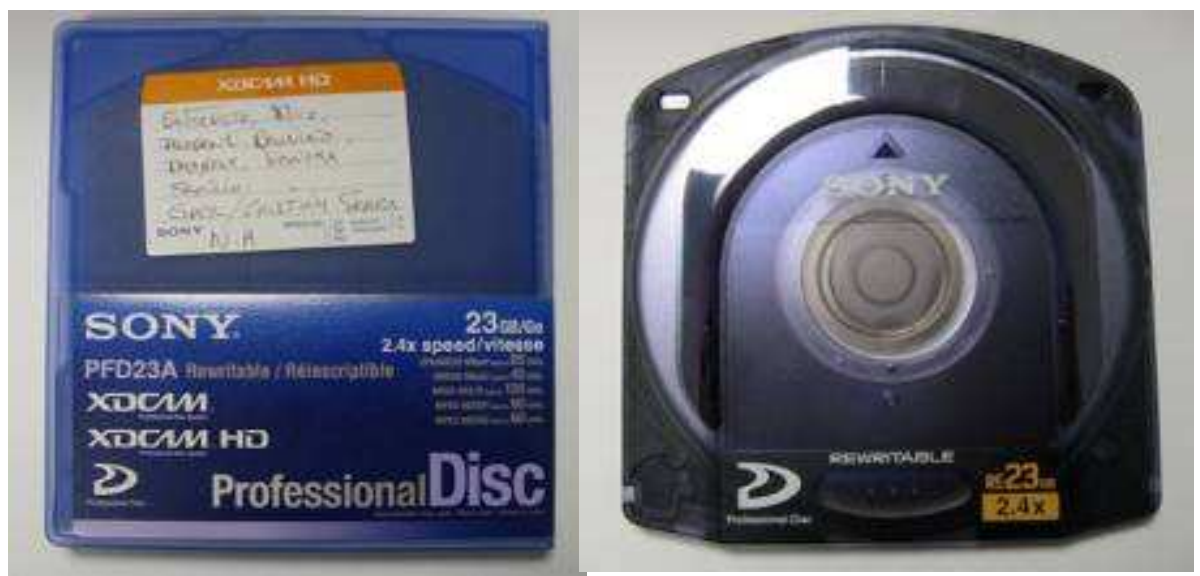

Figura 9: Discos ópticos 


\section{O ACERVO}

A conservação do acervo é feita utilizando estantes de metal revestidas com resina epóxi que evita a desmagnetização das fitas. Também há controle da temperatura (em torno de $17^{\circ} \mathrm{C}$ ) e da baixa umidade relativa com a instalação de um desumidificador. O nível de umidade deve ser mantido de modo que o material não resseque e se torne quebradiço. Também há um dispositivo de segurança contra incêndio. São 12 estantes deslizantes em uma sala com 5,2 x 6,0 m.

Estima-se que o acervo do Cedoc Brasília possua aproximadamente 8.200 horas de gravação de material em U-matic, Betacam e no formato digital. Não se sabe ao certo a quantidade de material em filme, pois em cada caixa do acervo estão contidos vários rolos sem uma padronização quanto à quantidade ou horas de gravação, mas se pode estimar que o acervo contenha mais de 10 mil horas de gravação, incluindo os filmes.

Tudo que é produzido pela TV Globo Brasília é arquivado no Cedoc. O acervo abrange toda a programação jornalística local além de matérias produzidas em Brasília que são veiculadas em rede, ou seja, em telejornais de cobertura nacional (Jornal Hoje, Jornal Nacional, etc). O Cedoc Rio também grava os telejornais de rede. Logo, matérias produzidas em Brasília que foram para a rede também são arquivadas lá. Este procedimento faz com que não seja preciso o Rio solicitar material de Brasília ou vice-versa. A solicitação é feita, obviamente, somente quando não há o material em uma das praças e ele é indispensável.

Também há material no Cedoc Brasília que não foi produzido na cidade, tais como imagens de portos, outras capitais do país e grandes cidades do mundo, cenas da Amazônia, trânsito de São Paulo, etc. Estes materiais, apesar de evidentemente não terem sido produzidos em Brasília, são importantes e bastante utilizados pelo jornalismo. Normalmente são imagens brutas, ou seja, aquelas imagens que não foram editadas e estão disponíveis para montagem de futuras reportagens. As imagens brutas costumam ser de longa duração, como, por exemplo, vários minutos de operários numa indústria, parlamentares no Congresso Nacional ou cena aérea de uma cidade. 
Quando um determinado material (imagem, videotape, etc.) não é encontrado em Brasília, é feita a solicitação às outras praças. Há quatro formas de envio de material: malote, Embratel (terrestre), satélite e um sistema de geração próprio.

Caso se opte pelo malote, o transporte é feito pelos Correios e pelas transportadoras e é cobrado preço de mercado. Quando a solicitação é urgente, é feita a geração via Embratel (terrestre) ou via satélite. Estas possuem custo por geração, normalmente por 10 minutos de sinal. A TV Globo Brasília, São Paulo e Rio possuem um sistema próprio de geração simultânea. O custo da instalação é altíssimo, mas não há custo para enviar sinal entre estas três praças. A emissora só usa o sinal pago caso as linhas do sistema próprio estejam ocupadas.

\subsection{A DIVISÃO DO ACERVO}

\subsubsection{AS CLASSES}

O acervo do Cedoc Brasília está dividido em várias classes, de acordo com o material ou o conteúdo. Os filmes estão na classe 40. O material de esporte encontra-se na classe 51. A produção de material esportivo é bastante pequena, se comparada com as praças São Paulo e Rio.

Entre 2000 e 2007 o Cedoc arquivou as entrevistas veiculadas no DFTV e Bom dia DF na classe 52. Este material se encontra todo decupado e disponível no acervo.

A Globo News ocupa a classe 53. Globo News é um canal da TV paga com programação exclusivamente jornalística 24 horas por dia. Seus principais programas são "Em cima da Hora", "Conta Corrente" e "Jornal das Dez", além de vários programas de entrevistas ao longo da programação.

A classe 50 é destinada aos videotapes de matérias produzidas por Brasília que foram veiculados nos telejornais de rede. Esta classe também abriga todas imagens brutas. Os telejornais locais são gravados na íntegra e inseridos na classe 55. São arquivados: Bom dia DF, DFTV $1^{\underline{a}}$ Edição e DFTV $2^{\mathrm{a}}$ Edição. 


\subsubsection{O MATERIAL TEMPORÁRIO}

No acervo também há um espaço destinado para programas gravados ao longo do mês, em caráter temporário. Todos os telejornais do dia são arquivados em fitas numeradas de 01 a 31, sendo cada uma destinada a um dia do mês. Na fita de número 10, por exemplo, será gravado o programa do dia 10 de cada mês. Assim, o jornal do dia 10 de agosto será gravado por cima daquele exibido no dia 10 de julho e assim por diante.

Este material em caráter temporário é disponibilizado para fins de consulta e fica disponível por um mês. É grande a demanda por empréstimo desses materiais por vários departamentos da emissora (redação, arte, etc). $O$ empréstimo é feito mediante cadastro do funcionário. É praticamente um serviço de referência. Os programas gravados em caráter temporário e emprestados são: Globo Rural (exibido durante a semana e aos domingos), Bom Dia DF, Bom Dia Brasil, DFTV 1ª Edição, Globo Notícia, Globo Esporte (local e nacional), Jornal Hoje, DFTV 2ª Edição, Jornal Nacional, Jornal da Globo, Radar (mostra o trânsito nas principais vias do DF pela manhã), Jornal das Dez (Globo News), Fantástico, Globo Repórter e Globo Ecologia.

Por algum tempo o Cedoc gravou em caráter temporário programas como Casseta e Planeta e Sai de Baixo, este último extinto ainda em 2002. O objetivo era manter material em standby para o caso de haver necessidade de se cobrir espaço vago na programação. Este procedimento não é mais necessário.

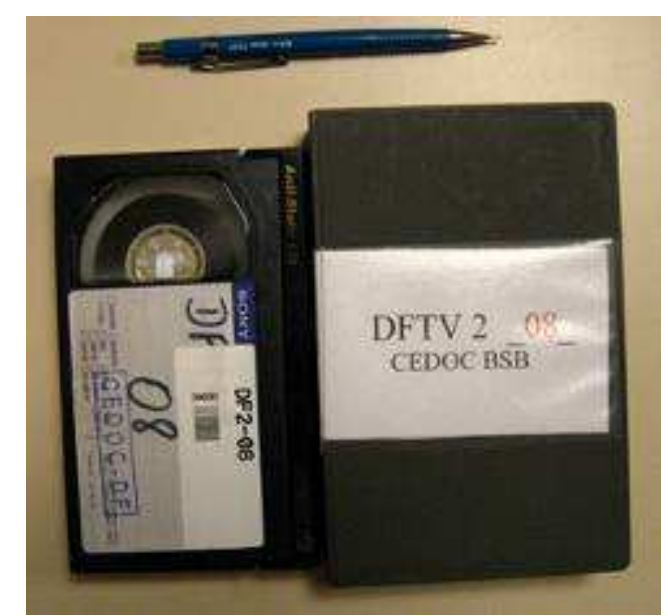

figura 10: Exemplo de gravação em caráter temporário - DFTV 2ª Edição, do dia 08 


\subsubsection{AGENDA CULTURAL}

Quando se aproxima o fim de semana, a primeira edição do DFTV apresenta um quadro chamado Agenda Cultural. Neste quadro, são divulgadas as principais atrações culturais da cidade para o fim de semana. São exposições, teatro, música, dança, cinema e shows em geral.

Os artistas que desejam divulgar os seus trabalhos enviam material para a emissora e o Cedoc por muito tempo se encarregou de copiar o material e manter em seu poder o original fornecido pelos artistas (ou produtores), temporariamente. $O$ acervo ainda possui um espaço destinado a este material, sendo este composto em sua maioria por DVDs e fitas Betacam. O trabalho de cópia e arquivamento do material da agenda cultural estava comprometendo o desempenho das atividades prioritárias do Cedoc. Por isto, este trabalho foi transferido para outro setor.

As ilustrações abaixo mostram tematicamente como é a distribuição do material do Cedoc Brasília.

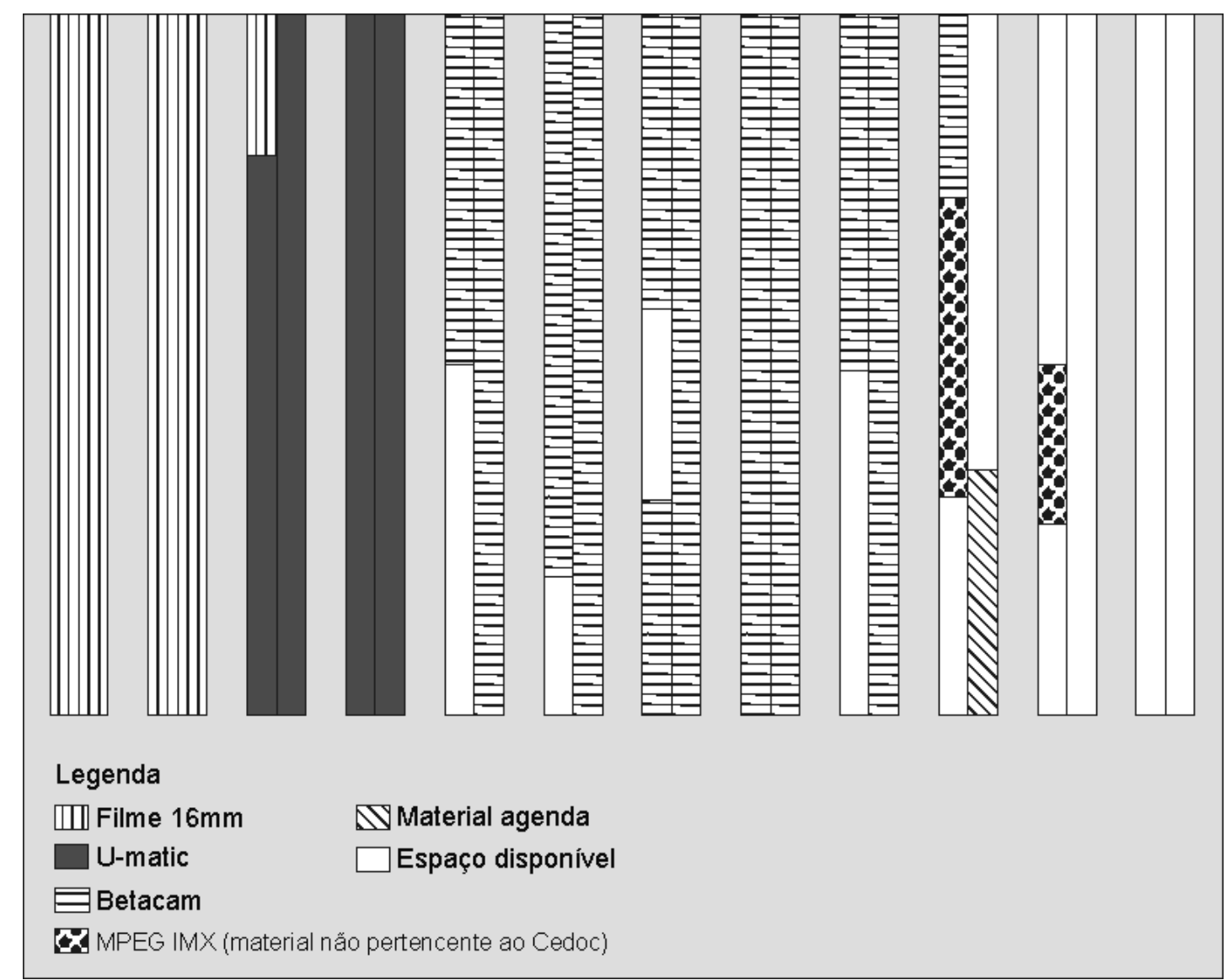

Figura 11: Mapa do acervo de acordo com a tecnologia de vídeo 


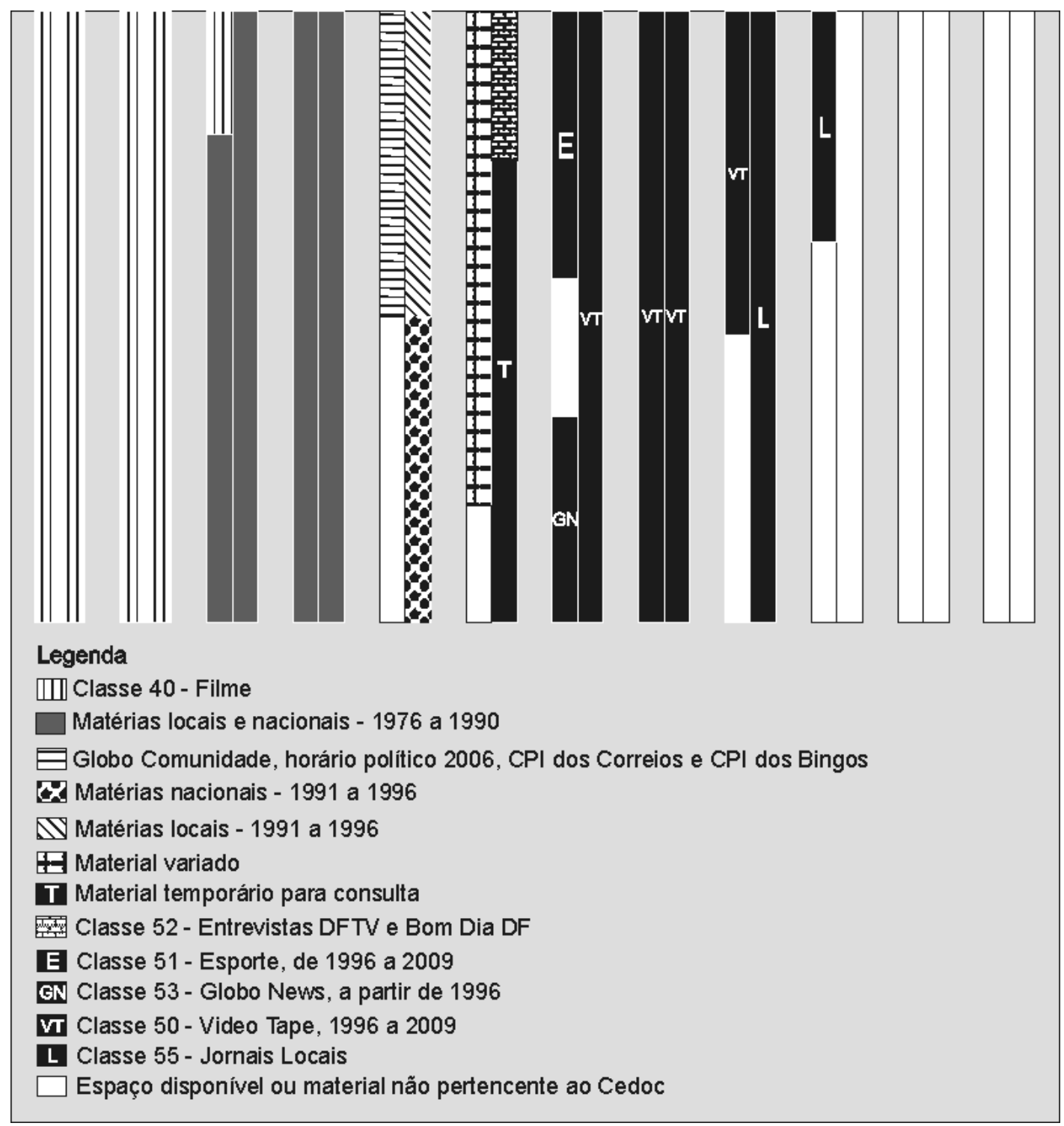

Figura 12: Mapa do acervo de acordo com as classes

\section{O CEDOC E OUTRAS EMISSORAS}

\subsection{MATERIAL CEDIDO PARA OUTRAS EMISSORAS}

Quando o assunto é a cessão de imagens para emissoras concorrentes, há sempre uma negociação. A TV Globo cede material a emissoras dispostas a fornecer reciprocidade. Trata-se de um jogo de interesses. Há emissoras para as quais a TV Globo jamais cede material. Há imagens, quando inéditas, que também não são cedidas.

Não é fornecido o banco de imagem, pois pode ser produzido pelas outras emissoras. Não é permitido ceder imagens que, mesmo estando em poder da TV 
Globo, não Ihe pertencem. Também não é permitido fornecer imagens brutas. Cada caso é negociado separadamente. Há casos, inclusive, de venda de imagem.

\subsection{MATERIAL ADQUIRIDO DE OUTRAS EMISSORAS}

Além de imagens cedidas por emissoras públicas, tais como TV Câmara e TV Senado, há muito material de emissoras comerciais. Em alguns casos é feita negociação de troca de imagens, como é o caso de futebol. Às vezes a TV Globo faz a cobertura de um jogo e a TV Bandeirantes, por exemplo, cobre outro. Então é feita a troca as imagens. Às vezes entram no ar com créditos da emissora cedente e às vezes não.

Há casos de contrato de cessão de imagens, como os que ocorrem com emissoras internacionais: CNN, Reuters, etc. A TV Globo compra alguns minutos diários das principais imagens mundiais e usa conforme acordos contratuais. A emissora também vende imagens para aquelas emissoras.

$\mathrm{Na}$ TV Globo existe um departamento internacional que cuida de todas as cessões de imagens para emissoras do mundo inteiro. Da mesma forma, cada caso é negociado separadamente. As negociações são feitas sempre com base na reciprocidade que é oferecida à emissora.

\section{O PROCESSO DE ARQUIVAMENTO}

As duas principais formas de se obter material para ser arquivado no Cedoc são: a gravação durante a programação e via tráfego de fitas. $O$ setor de tráfego de fitas se encarrega de enviar ao Cedoc todas as fitas contendo VTs (videotapes) que foram exibidos durante a programação jornalística da emissora. Um funcionário do Cedoc (geralmente um pesquisador) escolhe as fitas que serão arquivadas pelo Cedoc, seguindo determinados critérios, tal como evitar a duplicação de material, por exemplo.

Depois de selecionado o material, é feita a decupagem. Como foi dito anteriormente, decupagem, no jornalismo, é o processo de se inserir os dados do material no sistema (programa em que foi exibido, repórter, título da matéria, 
duração, data, etc), além da sinopse, onde é feita a descrição das imagens da matéria de modo que possam ser recuperadas posteriormente.

Feita a devida decupagem, o material está disponível no sistema, mas na base de dados temporária. Ele pode ser visto apenas no Cedoc Brasília. Somente após feita a indexação do assunto e das imagens o material em questão será transferido para a base de dados definitiva, o qual estará disponível para todas as praças da emissora. A fase de indexação e suas particularidades será descrita detalhadamente no decorrer do estudo.

\section{COMO SERÁ NO FUTURO}

Como dito anteriormente, a emissora está passando por reformulação tecnológica, entrando na era digital. Com a transmissão digital, na qual a TV Globo já está inserida, tudo será modificado nos próximos anos. Estima-se que no máximo em três anos, o trabalho do Cedoc será totalmente diferente do que é hoje.

As fitas cassete deixarão de ser usadas; serão usados discos ópticos. As imagens serão digitalizadas, guardadas em servidores gigantes e disponibilizadas para todos os computadores da emissora, tudo em tempo real. O trabalho será mais dinâmico e ágil. O Cedoc tende a ganhar maior importância dentro da emissora, já que as imagens serão submetidas a um novo procedimento: chegarão da produção, direto para os equipamentos do Cedoc, que terá que decupá-las e descrevê-las, na hora em que estiverem chegando. Só depois disso as imagens poderão ser utilizadas pelo jornalismo.

\section{RECURSOS HUMANOS}

O Cedoc Brasília conta hoje com 10 funcionários, sendo uma pesquisadora chefe, uma bibliotecária, três editores, três pesquisadores e dois estagiários distribuídos na estrutura ilustrada na Figura 13. 


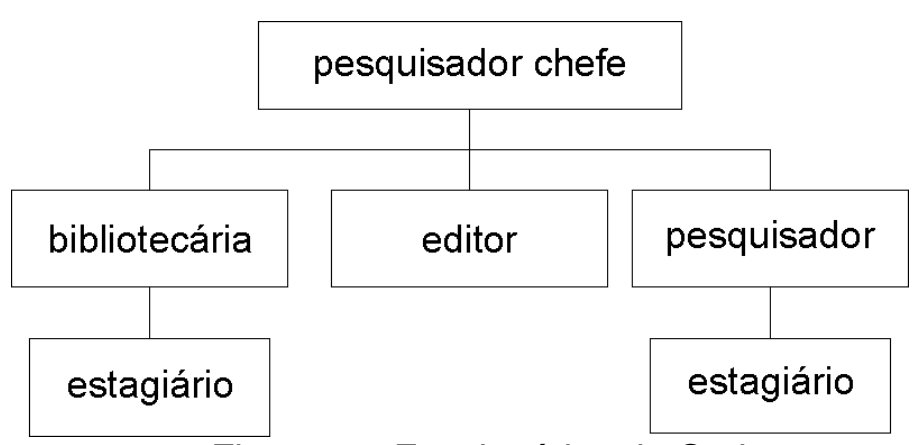

Figura 13: Funcionários do Cedoc

Dos três editores, dois possuem ensino médio e estão no Cedoc há 13 anos e um deles trabalha também em outro lugar. $O$ terceiro editor cursa jornalismo e está no Cedoc há menos de dois anos. Dois pesquisadores são jornalistas e o terceiro também cursa jornalismo. Eles possuem experiência entre 7 e 12 anos no Cedoc. $A$ bibliotecária trabalha no Cedoc há 13 anos e a pesquisadora-chefe é jornalista e trabalha na emissora há 23 anos.

Dentre as principais dificuldades que geram necessidade de mais treinamento do pessoal, estão: inovação tecnológica, atualização das ferramentas de trabalho e relacionamento interpessoal.

Apesar de não existir uma formação específica para preparar um profissional para lidar com arquivos audiovisuais, principalmente em se tratando de informações jornalísticas, não tem havido dificuldades para se contratar pessoal. Isto porque há a possibilidade de se treinar estagiários de diversas áreas. Inicialmente, dava-se preferência para os estagiários em jornalismo, mas alguns não se adaptaram e muitos queriam usar o Cedoc como trampolim para ingressar na Redação.

Uma nova tentativa foi feita com arquivistas, mas se esbarrava na necessidade de ensiná-los a linguagem jornalística. Por exemplo, ensinar o que era lead (título do documento no sistema), off (trecho de reportagem sem imagem), stand-up (apenas o repórter fala para a câmera), entre outros termos. Esta tentativa deu mais certo do que com os jornalistas, apesar das dificuldades. Hoje, estagiários de várias áreas são treinados, pois se acredita que todos têm algo a acrescentar à profissão. 
Os salários dos funcionários do Cedoc Brasília estão com uma grande defasagem em relação à própria emissora. Vários departamentos estão com programas de reajuste salarial e o Cedoc ainda não foi inserido. Muito tem sido tentado, mas a prática do dia-a-dia mostra que o Cedoc tem sido desvalorizado com seus baixíssimos salários e volume de trabalho crescente.

\section{A SINOPSE}

A sinopse é a fase da decupagem do material onde são descritas as imagens que constam na matéria, de acordo com termos e critérios jornalísticos. Não se trata simplesmente de fazer um resumo ou escrever aleatoriamente tudo que acontece na reportagem, e sim citar de forma breve e concisa as imagens que possam ser consideradas de importância arquivística, ou seja, possuem tamanha importância, que vão para o chamado arquivo permanente, supondo-se que no futuro alguém precisará delas. Por exemplo: numa reportagem sobre crescimento urbano, é bastante comum se mostrar cenas de favelas com seus barracos, lugares que tiveram crescimento desordenado. Estas imagens, devidamente registradas na sinopse e indexadas, podem ser reutilizadas para outras matérias sobre qualidade de vida, violência urbana, programas governamentais de habitação, entre outros temas nos quais seja necessário exibi-las. Um exemplo de sinopse é o que segue abaixo:

Título: ESTUDANTES FAZEM PASSEATA PEDINDO O IMPEACHMENT DO PRESIDENTE COLLOR

Sinopse: IMAGENS AÉREAS DA CHEGADA DE ESTUDANTES PARA MANIFESTAÇÃO NO GRAMADO EM FRENTE AO CONGRESSO NACIONAL / PASSEATA DE ESTUDANTES VESTIDOS DE PRETO NA W3 SUL / PASSEATA E CARREATA PELA ESPLANADA DOS MINISTÉRIOS PELA APROVAÇÃO DO RELATÓRIO DA CPI DO PC FARIAS PELO IMPEACHMENT DO PRESIDENTE FERNANDO COLLOR DE MELLO / ESTUDANTES COM A CARA PINTADA DE PRETO/

Depois de feita a sinopse, o documento em questão ainda permanece na base de dados temporária até que seja feita a indexação. Já é possível encontrá-lo no sistema através da busca, mas não através da indexação, pois isto ainda não foi feito. Os procedimentos de pesquisa serão detalhados mais adiante. Somente 
depois de feita a indexação o material será transferido para a base definitiva. A qualquer tempo é possível alterar a sinopse e a indexação do documento.

\section{O PROCESSO DE INDEXAÇÃO}

Sabe-se que o processo de indexação envolve duas fases: análise conceitual e tradução. Na análise conceitual, é feita uma leitura do documento de forma a assimilar e interpretar o conteúdo temático para extrair o que for considerado mais expressivo. Na tradução é feito o processo de indexação propriamente dito, no qual são inseridos os termos que melhor representam o documento. A modalidade de tradução utilizada no Cedoc é predominantemente a de atribuição, na qual são escolhidos termos previamente existentes em uma linguagem documentária, onde há controle de sinonímia, homografia, entre outros problemas que poderiam interferir de forma a dificultar o trabalho caso este fosse feito usando-se linguagem natural.

O procedimento de indexação no Cedoc é feito por bibliotecários. A fase de tradução possui duas partes: indexação de assunto e de imagem. É possível criar vários perfis durante a indexação. O primeiro perfil será sempre do assunto. Os demais serão destinados às imagens que constam na matéria. Por exemplo, uma reportagem sobre a prisão de traficantes de drogas em Samambaia seria indexada em dois perfis. No primeiro perfil, os termos de indexação (não há acentos ou cedilha nos termos do vocabulário controlado) inseridos seriam: TRAFICANTE, PRISAO, TOXICO, REPRESSAO AO TOXICO e SAMAMBAIA (CIDADE). Durante a reportagem, provavelmente seriam exibidas imagens dos traficantes presos, maconha e/ou cocaína apreendidas, dinheiro, armas, viaturas da polícia e fachada da delegacia. Assim, os termos inseridos no segundo perfil (o de imagens) seriam: IMAGEM, QUADRILHA (CRIMINOSOS), MACONHA, COCAINA, ARMA DE FOGO, CARRO DE POLICIA, DELEGACIA DE POLICIA. No perfil de imagem é necessário se colocar o termo IMAGEM. Todos estes termos são importantes por terem valor para as pesquisas e constantemente são feitas solicitações de imagens de drogas, viaturas da polícia, etc. Portanto, é necessário indexar o que se supõe que, no futuro, será solicitado pelo usuário. Muitas vezes os termos utilizados no perfil de imagens coincidem com aqueles usados no perfil destinado ao assunto. 
A Figura 14 mostra outro exemplo de indexação, no qual é feita atribuição de assunto, ainda que o mesmo não esteja explícito na reportagem. Pode-se ver os perfis 1 e 2 criados de acordo com o procedimento padrão adotado no Cedoc.

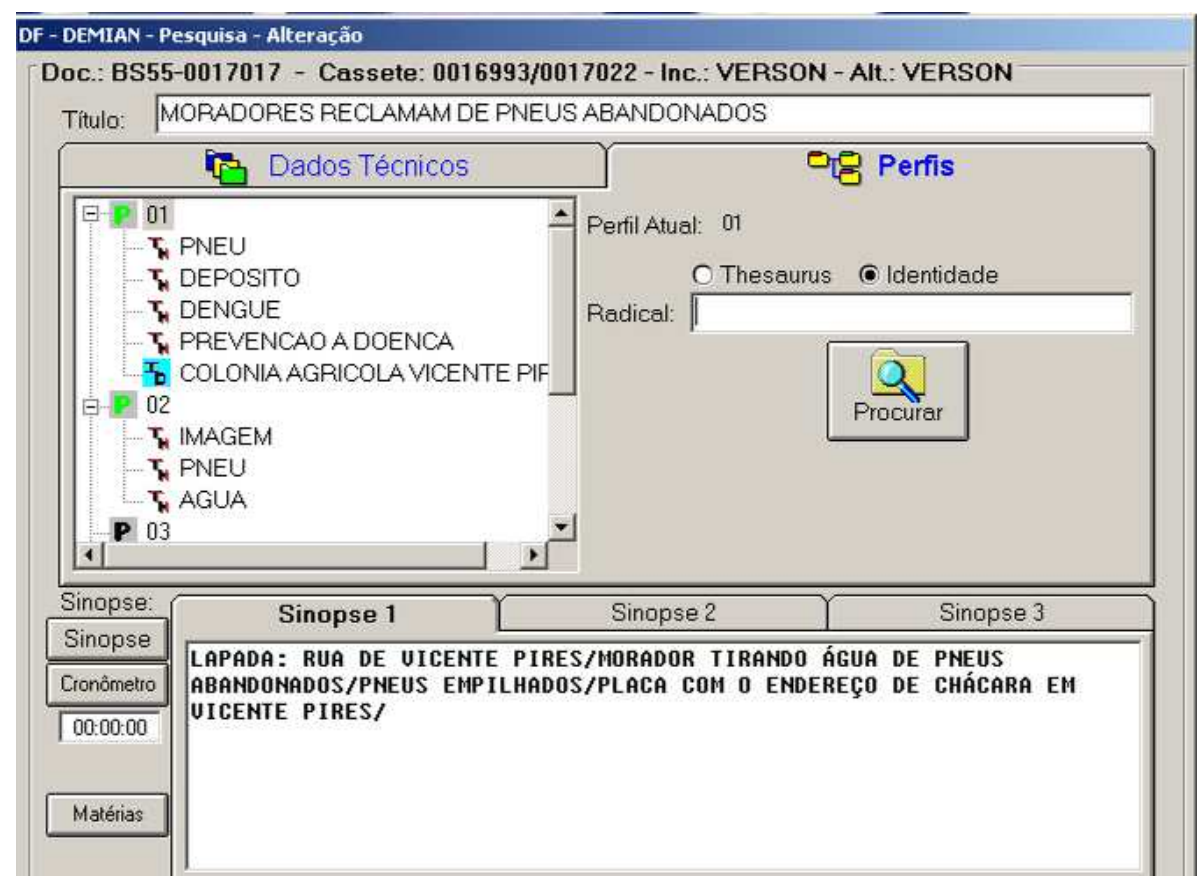

Figura 14: Exemplo de indexação

O lead (título) indica que a reportagem se trata apenas de moradores reclamando de pneus abandonados, mas o indexador inseriu os termos DENGUE e PREVENCAO A DOENCA. O motivo é simples. Como tem sido amplamente difundido e alertado à população que pneus abandonados acumulam água atraindo o mosquito transmissor da dengue, além da sinopse indicar que há imagem de uma pessoa retirando água de pneus, o indexador entendeu que as imagens poderiam ser reutilizadas em outra reportagem sobre casos de dengue ou prevenção à doença, ainda que o documento em questão, que está sendo indexado, não aborde o tema especificamente. Para isto, é necessário possuir certa intuição jornalística, além de conhecimentos gerais em nível razoável. Com este raciocínio proativo, supõe-se que os produtores do jornalismo no futuro solicitarão ao Cedoc imagens desse tipo para montar uma matéria sobre medidas de prevenção contra a dengue.

Nem sempre o indexador domina o assunto que está sendo abordado. Às vezes é preciso recorrer à ajuda de um especialista ou pesquisar sobre o assunto na 
Internet, obviamente em fontes confiáveis. Isto ocorre com bastante frequência em assuntos que costumam possuir jargões ou termos técnicos, como economia. Por exemplo, uma reportagem dizia que o Governo Federal anunciou a abertura do capital da Petrobrás. No primeiro momento, pensou-se que se tratava de privatização. Diante da remota possibilidade de tal acontecimento, outra opção era se pensar em terceirização. Como não havia certeza alguma e não se contava com um especialista em economia por perto, foi necessário consultar uma fonte especializada na área para saber o que significa a abertura de capital de uma empresa. Descobriu-se que se tratava apenas de se conceder permissão aos investidores externos para comprarem ações de uma empresa que até então eram restritas a uma sociedade limitada. $O$ assunto não tem relação alguma com terceirização, muito menos privatização. Portanto, os termos de indexação seguiram outro rumo, diferente do pensado inicialmente.

Em diversos assuntos é necessário que o indexador esteja inteirado de suas origens e seus desdobramentos até se chegar à reportagem que está em suas mãos para ser indexada. Para se indexar, por exemplo, uma reportagem cujo título seja "Protógenes Queiroz presta depoimento na CPI da Câmara", é necessário saber o que foi a Operação Satiagraha da Polícia Federal, as escutas telefônicas clandestinas, a prisão do banqueiro Daniel Dantas, o papel do presidente do Supremo Tribunal Federal no caso, para se entender quem é quem na história, do que o delegado Protógenes está sendo acusado, o motivo de seu depoimento, etc. De posse de todas essas informações, é possível indexar a reportagem de modo preciso. Às vezes a matéria não traz um histórico do caso, supondo que a pessoa que assiste já está ciente do que se trata.

Outro grande exemplo da necessidade de atualização do indexador é o caso da libertação de Ingrid Bettancourt, fato que repercutiu na imprensa internacional. Para se indexar as inúmeras reportagens da época, foi necessário saber: quem é Ingrid Bettancourt, o que são as FARC (Forças Armadas Revolucionárias da Colômbia), as ideologias que motivaram o sequestro, os países envolvidos, o papel dos presidentes da Venezuela e da França, etc. Como dito anteriormente, é necessário possuir nível satisfatório de conhecimentos gerais. 
O indexador às vezes é tentado a atribuir juízo de valor, baseado em posições pessoais. É necessário se manter imparcial e jamais proferir opinião, mesmo que o assunto a ser indexado seja algo que vá contra suas convicções políticas, religiosas, morais, etc. $\mathrm{O}$ fato de uma reportagem abordar crimes cometidos por menores de idade não dá ao indexador o direito de usar o termo CRIMINOSOS, sendo que existe a opção MENOR INFRATOR, que é a opção correta de acordo com a lei. Por mais que o crime praticado pelo menor tenha sido bárbaro, não é correto utilizar o termo anterior por ser juridicamente incorreto. Da mesma forma, o indexador, ainda que não seja católico, jamais poderá usar o termo LENDA quando se tratar de uma reportagem sobre uma possível aparição de Nossa Senhora. Para isto, existe o termo APARICAO (RELIGIAO). O termo anterior, além de ser antiético quando usado neste caso, é utilizado apenas quando o assunto envolve o folclore, contos de fadas, mitologia, etc.

A Figura 15 mostra um exemplo de indexação de reportagem, na qual há entrevista de uma personalidade durante a reportagem:

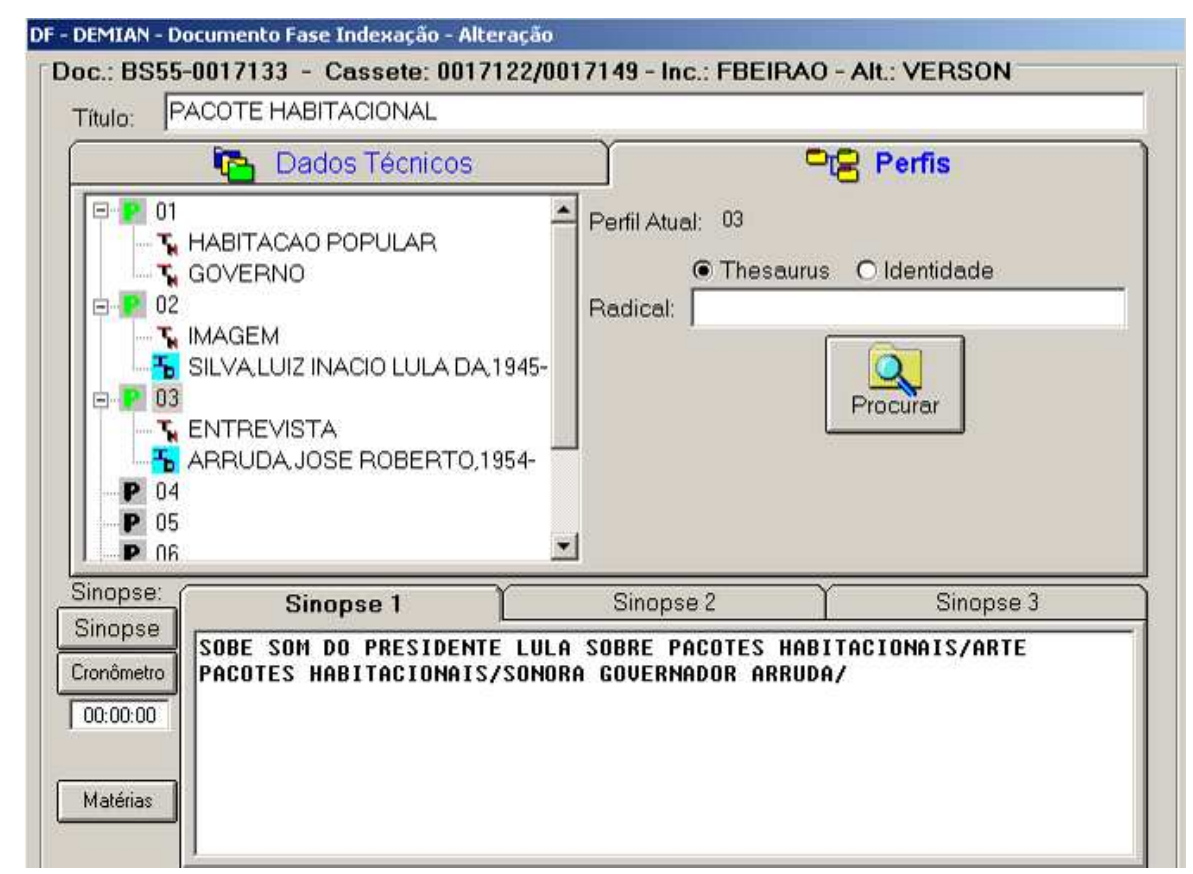

Figura 15: Exemplo de indexação contendo entrevista

Além da necessidade de se estar atualizado e possuir nível satisfatório de conhecimentos gerais como mostrado nos exemplos anteriores, o indexador também 
precisa conhecer alguns termos específicos da área de jornalismo. Neste exemplo, aparecem duas personalidades na matéria: o Presidente Luiz Inácio Lula da Silva e - Governador do Distrito Federal, José Roberto Arruda. Na sinopse, a expressão "sobe som" indica que o Presidente Lula não está falando diretamente ao microfone do repórter. Neste caso, ele está discursando. "Arte" indica que há alguma animação na reportagem. Na reportagem em questão, são os números do investimento do governo no pacote habitacional. Já a expressão "sonora" indica que o Governador Arruda está concedendo uma entrevista ao repórter da TV Globo.

No momento de montar os perfis da indexação é feita a divisão: um perfil para - assunto, outro para as imagens e um terceiro para agrupar as pessoas importantes que deram entrevista. Em alguns casos, é necessário criar vários perfis. Cada caso é analisado separadamente. Neste exemplo, o assunto é o pacote habitacional do governo para financiar casas populares. Para tal, foram usadas as expressões HABITACAO POPULAR e GOVERNO. Como nesta reportagem há apenas a imagem do Presidente Lula discursando longe da câmera, seu nome foi incluído no perfil de imagem, junto ao termo IMAGEM. Já o Governador Arruda concede entrevista ao repórter da TV Globo. Por isto seu nome foi incluído no terceiro perfil criado para agrupar as entrevistas, juntamente com o termo ENTREVISTA.

Depois de indexado, o documento passa a fazer parte da base de dados definitiva. É possível alterá-lo a qualquer tempo (sinopse ou indexação) e encontrálo em todas as praças através da busca utilizando a linguagem documentária, na qual se usa o tesauro e o dicionário de identidades, que serão expostos detalhadamente no decorrer do estudo. Também será discorrido a respeito das duas formas de se realizar pesquisas: por vocabulário controlado e a busca livre.

\subsection{POLÍTICA DE INDEXAÇÃO DE ASSUNTOS GERAIS}

O principal objetivo de se implantar um serviço de indexação é assegurar que as informações sejam encontradas no tempo preciso, de maneira eficiente e eficaz. Para tanto, torna-se necessário implantar uma política de indexação que leve em conta variáveis essenciais como a natureza da organização, identificação do perfil 
do usuário, recursos humanos, etc. Desta forma, foi elaborada uma política de indexação para o Cedoc de toda a emissora, que englobasse as demais praças, unificando e padronizando a maneira de se recuperar a informação solicitada. A política é elaborada a partir da sede no Rio de Janeiro e esporadicamente sofre algumas alterações. Estas alterações são comunicadas às praças e suas orientações devidamente seguidas.

A seguir, traremos vários exemplos de situações e como proceder segundo a política de indexação adotada pelos bibliotecários da emissora.

\subsubsection{LOCAL}

É necessário indicar o local quando este for indispensável para a recuperação da matéria e quando for necessário para possibilitar pesquisas de caráter geral sobre o estado, país, etc. Proceder da mesma forma em assuntos como criminalidade, poluição, acidentes automobilísticos, guerras, manifestações ou turismo, por exemplo.

\subsubsection{ENTREVISTAS}

No caso de entrevistas feitas em estúdio, indicar sempre o assunto da entrevista, a não ser que o assunto seja o próprio entrevistado, ou o exercício de sua função. Por exemplo: em entrevista com o Ministro Gilmar Mendes sobre a sua carreira como jurista, indicar na indexação: ENTREVISTA e MENDES, GILMAR. No caso de entrevista com o Ministro sobre as invasões de terras promovidas pelo MST, indicar: ENTREVISTA, MENDES, GILMAR, MST e INVASAO.

\subsubsection{ACIDENTES NATURAIS}

Em caso de acidentes ligados a fenômenos da natureza, a recuperação das matérias deve ser feita com os termos mais apropriados, sem limitar o assunto. Maiores detalhes podem ser pesquisados no vocabulário livre. Por exemplo, na reportagem abaixo: 
Título: ENCHENTES EM SANTA CATARINA DEIXAM MILHARES DE DESABRIGADOS

Sinopse: EQUIPES DA DEFESA CIVIL COM BOTE / RESGATE DE MORADOR COM BÓIA / LOCAL ONDE HOUVE DESMORONAMENTO / CASA SOTERRADA / LAMA NO INTERIOR DE CASAS / VISTA GERAL DA CIDADE DE ITAJAÍ COM ENCHENTE / MARCA NA PAREDE COM NÍVEL DE ÁGUA / SOLDADOS DO EXÉRCITO DESEMBARCANDO DE HELICÓPTERO / RUAS ALAGADAS / CRIANÇAS EM CIMA DE TELHADO / HOMENS CARREGANDO GELADEIRA POR RUA ALAGADA / GALPÃO ONDE ESTÃO DESABRIGADOS

No perfil de assunto, indicar ENCHETE, CHUVA, SANTA CATARINA (ESTADO) e DESABRIGADOS. Já no perfil de imagem, incluir IMAGEM, ENCHENTE, DESABAMENTO, RESGATE, DEFESA CIVIL, HELICOPTERO, BRASIL.EXERCITO e DESABRIGADOS. A cidade de Itajaí não consta no vocabulário controlado. Portanto, seria preciso fazer a busca pelo vocabulário livre caso necessário. Não foi necessário usar os termos GELADEIRA, CRIANCA ou AGUA, pois não possuem valor para a pesquisa, mesmo que estejam presentes na reportagem. Isto quer dizer que o termo GELADEIRA, por exemplo, deverá ser usado apenas em imagens de geladeiras nas lojas de eletrodomésticos para serem usadas em reportagem sobre a queda nas vendas de produtos chamados linha branca ou sobre o consumo de energia elétrica, por exemplo.

\subsubsection{VIAGENS OFICIAIS}

Nas viagens oficiais do Presidente da República, governadores ou autoridades governamentais cuja viagem se considere de relevância, usar VIAGENS GOVERNAMENTAIS, nome do país e identidade da autoridade que fez a viagem. Por exemplo: "Presidente Lula se encontra nesta terça com primeira-ministra alemã em Berlim". Indexar com VIAGENS GOVERNAMENTAIS, ALEMANHA (PAIS), SILVA,LUIZ INACIO LULA DA e MERKEL,ANGELA. Como a primeira-ministra Ângela Merkel está presente na reportagem e ela está cadastrada no Dicionário de Identidades (que será exposto mais adiante), seu nome também deverá ser inserido. 


\subsubsection{ESCÂNDALOS}

O caso do escândalo do mensalão, que foi a compra de votos de deputados da base governista para aprovarem projetos de interesse do Governo Federal, foi um grande exemplo da necessidade de se criar uma política de indexação para se padronizar um assunto de grande relevância. As principais orientações foram:

- A recuperação das imagens brutas das CPIs e outros depoimentos tiveram entradas apenas para o depoente, sem imagem dos deputados que faziam perguntas na mesma. Comportamento, frases e outros foram recuperados somente nas matérias editadas que deram ênfase a tais fatos;

- Cruzar o depoente com o caso em questão, com a CPI e com o local. Por exemplo: DEPOIMENTO (TESTEMUNHO), JEFFERSON.ROBERTO, CASO DO MENSALAO, CPI E BRASIL.CONGRESSO;

- Para as matérias de denúncia, atentou-se quanto à necessidade ou não do termo DENUNCIA. No caso das CPIs, se não fosse alguma denúncia nova e de impacto, já estaria implícito;

- Utilizar os termos CRISE e PT(BRASIL) para recuperar matérias que falassem da crise do PT. Por exemplo, "Tarso Genro se reúne com a direção do PT para traçar um plano de emergência";

\subsubsection{ASSASSINATO e MORTE}

Sempre que se usa o termo ASSASSINATO, não é necessário utilizar o termo MORTE, pois sempre que ocorre um assassinato está implícito que houve uma morte. O uso da palavra controlada "morte" será usada nos casos em que a palavra é necessária, por exemplo, morte de uma personalidade, acidente que resultou em morte, etc. 


\subsubsection{MANIFESTAÇÃO}

Deve-se usar o termo MANIFESTACAO associado ao local da manifestação e se houver um assunto a ser cruzado. Uma manifestação na Avenida Paulista contra a corrupção, por exemplo, deverá ser recuperada com os termos MANIFESTACAO, PAULISTA (AVENIDA) e CORRUPCAO.

Só usar este termo associado à identidade de alguma organização se esta estiver participando da manifestação ou for motivo desta. Por exemplo, manifestação em frente ao STF contra a liberação das pesquisas com células-tronco: MANIFESTACAO, BRASIL.SUPREMO TRIBUNAL FEDERAL e CELULA-TRONCO.

\subsubsection{ECONOMIA}

O termo RELACOES ECONOMICAS é utilizado quando o assunto se referir a economia, comércio, exportação, importação, protecionismo, etc., entre países. Já os termos CONSUMO e CONSUMIDOR não devem ser confundidos com MERCADO CONSUMIDOR. Consumo é o ato de adquirir certo produto ou produtos. Abaixo, alguns termos usados em determinadas situações:

Título: "Preço do aluguel na Zona Norte está desvalorizado pela violência". Usar MERCADO IMOBILIARIO;

Título: "Mulheres solteiras têm mais facilidade para conseguir emprego". Usar MERCADO DE TRABALHO;

Título: "Produtos específicos são lançados para os solteiros, negros e idosos". Usar MERCADO CONSUMIDOR.

Quando o assunto é indústria, usar o termo mais específico possível, quanto ao tipo de indústria (automobilística, de bebidas, de construção, bélica, eletrônica, farmacêutica, química, etc). Quando não houver especificidade, cruzar sempre com o produto em questão, como, por exemplo, INDUSTRIA e COSMETICOS. 


\subsubsection{OUTRAS ORIENTAÇÕES}

A política de indexação ainda trata outros assuntos, tais como: guerras, curiosidades, instruções para indicação de closes, citações, shows, indicação de prefeituras de capitais, comportamento, etc. As situações relatadas nas seções anteriores são as mais significativas que respondem pela maior parte do trabalho de indexação no Cedoc.

\subsection{POLÍTICA DE INDEXAÇÃO PARA ESPORTES}

A cobertura de esportes locais também é feita pela TV Globo. É inegável dizer que a produção é pequena se comparada às praças Rio e São Paulo, onde se concentram os grandes times de futebol, maior variedade de modalidades esportivas, atletas com maior expressão nacional, etc.

Brasília não tem um time de futebol que atue na primeira divisão do Campeonato Brasileiro. Os times locais são inexpressivos e seus atletas desconhecidos. Nas outras modalidades, esporadicamente algum atleta consegue se destacar e, alguns têm conseguido medalhas nos jogos mais importantes, como as Olimpíadas de Pequim.

Diante disto, a indexação de esportes usada na TV Globo é bem mais simples que a adotada no Rio, apesar de teoricamente a política ser a mesma. Na praça Rio há um setor especializado de indexação de esportes, especialmente em futebol, na qual são abordados e recuperados todos os detalhes. Em Brasília, a indexação do futebol segue a seguinte estrutura, de forma bastante simplificada:

Perfil 1: Nome do campeonato, time1 e time 2

Perfil 2: IMAGEM, GOL e time 1

Perfil 3: IMAGEM, GOL e time 2

Esta é a estrutura geral adotada em jogos nos quais há gols de ambos os times. Haverá apenas um perfil de imagem para cada time, ainda que este tenha marcado vários gols. Caso o time não tenha marcado, obviamente não é necessário criar um perfil de imagem. O exemplo abaixo é uma indexação de uma matéria de futebol, feita em Brasília: 
Título: Brasiliense 2 x 1 Gama - Candangão 2008

Perfil 1: CAMPEONATO BRASILIENSE DE FUTEBOL, BRASILIENE e GAMA (CLUBE DE FUTEBOL)

Perfil 2: IMAGEM, GOL e BRASILIENSE

Perfil 3: IMAGEM, GOL e GAMA (CLUBE DE FUTEBOL)

Em caso de briga no futebol, o termo VIOLENCIA deverá ser inserido quando for para ressaltar agressão entre torcidas, entre jogadores, etc. Já o termo BRIGA será usado em casos de discussão ou crise muito acirrada entre os jogadores. Sempre cruzar violência com o esporte em questão, recuperando no perfil da briga, a identidade dos atletas e os times, se for o caso.

Os vários tipos de gols não são recuperados pela indexação. A recuperação de gol de bicicleta, gol de cabeça, gol de peixinho, entre outros tipos, deverá ser feita pelo vocabulário livre. No perfil da imagem do gol, é necessário incluir a identidade do jogador, caso exista.

No basquete, o único lance que se recupera é a cesta de 3 pontos ou alguma cesta espetacular. No vôlei, lances como saque e cortada deverão ser recuperados pelo vocabulário livre. No tênis, toda a recuperação será pelo vocabulário livre. A indexação deste esporte indica apenas a modalidade (tênis masculino ou feminino).

Os termos BICICLETA, BOLA NA TRAVE, CABECADA, CARTAO VERMELHO, CARTAO AMARELO, CARRINHO, DRIBLE, FALTA (ESPORTE), DEFESA (GOLEIRO), TRAVE, ULTRAPASSAGEM, SAQUE (JOGADA), PENALTI entre outros, apesar de constarem no tesauro, deverão ser usados somente em matérias específicas, cujo termo seja o assunto principal ou lances excepcionais.

\section{AS DIFICULDADES E CASOS CURIOSOS}

Indexar material jornalístico é um desafio de todos os dias. Cada documento é diferente do outro; é comum deparar-se com situações que geram dúvidas quanto à melhor forma de recuperar uma informação. O desafio é pensar em como será o comportamento do usuário no futuro. A pergunta a ser feita é: daqui a alguns meses 
ou anos, a pessoa que precisar deste material, vai pensar desta forma? Traremos alguns exemplos de situações que costumam gerar dúvidas na Tabela 1.

Tabela 1 - Exemplos de dúvidas durante a indexação

\begin{tabular}{|c|c|}
\hline $\begin{array}{l}\text { Termos afins que geram } \\
\text { dúvidas na escolha }\end{array}$ & A solução encontrada \\
\hline $\begin{array}{l}\text { ESTELIONATO ou } \\
\text { FRAUDE ou } \\
\text { FALSIFICACAO }\end{array}$ & $\begin{array}{l}\text { Ambos são crimes muito parecidos que causam } \\
\text { confusão ao indexador. As matérias não fornecem } \\
\text { detalhes suficientes para diferenciar uns dos outros. } \\
\text { ESTELIONATO - usar quando a matéria tratar de } \\
\text { golpe no qual haja algum esquema financeiro como } \\
\text { sócios "laranjas", empresas de fachada, etc; } \\
\text { FRAUDE - usar para golpes comuns como falso } \\
\text { emprego, prêmios inexistentes, dinheiro fácil, assim } \\
\text { como adulteração de combustíveis; } \\
\text { FALSIFICAÇÃO - quando o assunto central for a } \\
\text { prática de falsificação e a mesma estiver explícita, } \\
\text { como dinheiro falso, falsificação de documentos, de } \\
\text { assinatura, cheque falso, etc. }\end{array}$ \\
\hline $\begin{array}{l}\text { RECEITA FEDERAL OU } \\
\text { RECEITA FEDERAL DO } \\
\text { BRASIL }\end{array}$ & $\begin{array}{l}\text { A chamada "Super Receita" foi criada em } 2005 \text { com o } \\
\text { objetivo de unificar os serviços prestados pela } \\
\text { Receita Federal e da Receita Previdenciária. } \\
\text { Começou a funcionar em maio de 2007. Assim, o } \\
\text { termo a ser usado em matérias posteriores a maio de } \\
2007 \text { deverá ser RECEITA FEDERAL DO BRASIL. }\end{array}$ \\
\hline $\begin{array}{l}\text { OBRAS ou CONSTRUCAO } \\
\text { ou OBRAS PUBLICAS }\end{array}$ & $\begin{array}{l}\text { OBRAS - usar quando a obra em questão for } \\
\text { importante para a recuperação sem ser o assunto } \\
\text { principal; } \\
\text { CONSTRUCAO - usar quando a obra for o assunto } \\
\text { principal e para indicar construção civil. Imagens de } \\
\text { pedreiros, operários em andaime, esqueleto de } \\
\text { prédios, etc; } \\
\text { OBRAS PUBLICAS - exclusivamente para obras do } \\
\text { governo, tais como saneamento, asfalto, construção } \\
\text { de hospitais, escolas, etc. }\end{array}$ \\
\hline $\begin{array}{l}\text { ANIMAL DE ESTIMACAO } \\
\text { ou ANIMAL DOMESTICO }\end{array}$ & $\begin{array}{l}\text { ANIMAL DE ESTIMACAO - usar para animais } \\
\text { criados em casa como companhia; } \\
\text { ANIMAL DOMÉSTICO - para animais que } \\
\text { complementam a alimentação de uma família ou } \\
\text { ajudam de algum modo na casa (ex: galinha). }\end{array}$ \\
\hline
\end{tabular}


Em alguns casos, esbarra-se na dificuldade causada pelo excesso de informação na matéria que poderá causar ambiguidade. Na Tabela 2, dois exemplos:

Tabela 2 - Excesso de informação causando ambiguidade

\begin{tabular}{|c|c|c|}
\hline Assunto da matéria & O problema & A solução \\
\hline $\begin{array}{l}\text { Sequestradores de casal } \\
\text { no Lago Sul foram presos } \\
\text { em Planaltina. }\end{array}$ & $\begin{array}{l}\text { O que é mais importante } \\
\text { indicar? Lago Sul, onde o } \\
\text { crime foi cometido ou } \\
\text { Planaltina, onde os } \\
\text { bandidos foram presos? } \\
\text { Se os dois locais forem } \\
\text { incluídos, pode-se pensar } \\
\text { o inverso, ou seja, que o } \\
\text { crime fo cometido em } \\
\text { Planaltina e os bandidos } \\
\text { presos no Lago Sul. }\end{array}$ & $\begin{array}{l}\text { Decidiu-se que o local a } \\
\text { ser indicado na indexação } \\
\text { será sempre onde o crime } \\
\text { foi cometido. Portanto, os } \\
\text { termos utilizados foram: } \\
\text { PRISAO, } \\
\text { SEQUESTRADOR, LAGO } \\
\text { SUL e CASAL } \\
\text { O termo CASAL foi usado } \\
\text { para especificar este } \\
\text { seqüestro em meio a } \\
\text { tantos outros. }\end{array}$ \\
\hline $\begin{array}{lll}\text { Gerente de posto } & \text { de } \\
\text { gasolina é assaltado no } \\
\text { banco. }\end{array}$ & $\begin{array}{l}\text { Ao colocar os termos: } \\
\text { ASSALTO, POSTO DE } \\
\text { COMBUSTIVEIS e } \\
\text { BANCO (INSTITUICAO } \\
\text { FINANCEIRA) juntos, } \\
\text { pode-se pensar que o } \\
\text { assalto ocorreu no posto. }\end{array}$ & $\begin{array}{l}\text { Como no exemplo } \\
\text { anterior, o local a ser } \\
\text { indexado será onde o } \\
\text { crime foi cometido. Então } \\
\text { os termos utilizados } \\
\text { foram: } \\
\text { ASSALTO, } \\
\text { BANCO (INSTITUICAO } \\
\text { FINANCEIRA) e } \\
\text { COMERCIANTE }\end{array}$ \\
\hline
\end{tabular}

O trabalho de indexação, apesar de exigir atenção e concentração, às vezes lida com documentos que proporcionam momentos, no mínimo, divertidos. Como exemplo, pode-se citar o caso da reportagem de março de 2009, na qual há um flagrante de morador jogando lixo em local proibido. Ao ser flagrado, ele se defende dizendo possuir vários títulos acadêmicos, como se isto the desse o direito de sujar a cidade. Para situações como esta, no mínimo bizarra, costuma-se utilizar o termo FRASE(CITAÇÃO). Abaixo, o documento com sua sinopse: 
Título: FLAGRANTE - ENTULHO SENDO JOGADO EM LOCAL PROIBIDO

Sinopse: HOMEM COM CARRINHO DE MÃO DESPEJA LIXO EM LOCAL PROIBIDO/POVO FALA/ SONORA VITÓRIO CAMPOS DA SILVA, CHAMADO "DONO" DA 704 SUL - CITANDO SEUS DIPLOMAS: "EU, COMO PROFESSOR DO DEPARTAMENTO DE BIOQUÍMICA DA UNIVERSIDADE DE BRASÍLIA, FORMADO EM ODONTOLOGIA, EM MATEMÁTICA, PÓS-GRADUADO EM PERIODONTIA E IMPLANTODONTIA, MESTRE EM IMPLANTODONTIA E DOUTOR NO NÚCLEO DE PROTEÔMICA DA UNB, CONSCIENTEMENTE, ESTOU TRANSPORTANDO O LIXO, QUE É O RESULTADO DO CORTE DA NOSSA GRAMA, QUE O CARROCEIRO VIRÁ APANHÁ-LA"

Frases polêmicas ditas por alguma personalidade (as diversas gafes cometidas pelo Presidente Lula quando ele discursa de improviso, por exemplo) devem ser escritas integralmente na sinopse para que o documento seja recuperável através da busca pelo vocabulário livre. O caso do professor, apesar do personagem em questão não ser uma personalidade, o indexador considerou importante registrar a atitude desrespeitosa seguida de uma "pérola" dita por alguém que teoricamente deveria dar o exemplo de civilidade.

Situações engraçadas, principalmente no meio político, costumavam ser recuperadas a pedido do jornalista Alexandre Garcia que, por algum tempo, apresentou um quadro de sátira política com os fatos da semana durante 0 Fantástico. Para tais situações, além de ser necessário registrar o fato na sinopse, o indexador usa os termos COMPORTAMENTO, CURIOSIDADES, FRASE (CITACAO) e SATIRA POLITICA, de acordo com a sua necessidade, analisada caso a caso. $O$ exemplo abaixo ilustra bem estes casos:

Título: CRÔNICA DE ALEXANDRE GARCIA

Sinopse: DEPUTADO JOSÉ FREJAT DANDO UM NÓ EM FIO DE TELEFONE / SENADOR BOLIVAR MOURA ROCHA RESPONDE AS PERGUNTAS TENTANDO ENROLAR OS REPÓRTERES / SÉRGIO CUTOLO DÁ ENTREVISTA E SUA FILHA INTERROMPE / REINHOLD STEPHANES TEM UM BRANCO DURANTE UMA ENTREVISTA / DEPUTADO FERNANDO GABEIRA COMENDO E DISTRIBUINDO PÃO DURANTE DISCUSSÕES NA COMISSÃO 


\section{A LINGUAGEM DOCUMENTÁRIA}

A linguagem documentária, chamada no Cedoc de Vocabulário Controlado (VC), é composta pelo Thesaurus e Dicionário de Identidades. O VC é amplamente utilizado pelos pesquisadores do Cedoc, pela facilidade de se recuperar material filtrado. Ele ajuda a solucionar pesquisas que geram dúvidas como, por exemplo, em nomes comuns, com homônimos: Roberto Carlos (cantor ou jogador de futebol?), Bebeto (ex-jogador de futebol, dirigente esportivo ou cantor?), Arruda (político ou planta?), George Bush (pai ou filho?), entre outros.

O VC também auxilia a pesquisa quando se tem várias palavras sinônimas. Seria impossível estabelecer uma padronização das sinopses. Exemplo: Morto, cadáver, corpo, etc. Sem o VC, seria necessário que o pesquisador se lembrasse qual foi o termo utilizado pela pessoa que escreveu a sinopse para realizar a busca pelo vocabulário livre. Sobre as modalidades de busca, serão expostas mais adiante.

\subsection{O THESAURUS}

O Thesaurus foi desenvolvido pela equipe de bibliotecários do Cedoc Rio, sendo o mesmo utilizado em todas as praças da emissora. Assim, todos os termos que constam no Thesaurus do Cedoc São Paulo também serão encontrados em Belo Horizonte, por exemplo. As atualizações são feitas a partir da matriz e repassadas a todas as praças para que mantenham a padronização.

Até 15 de abril de 2009, havia 8.708 termos inseridos no Thesaurus. Muitos são de grande importância. Mas há outros cuja utilidade é questionável. Os termos do Thesaurus no momento da indexação são apresentados da seguinte forma:

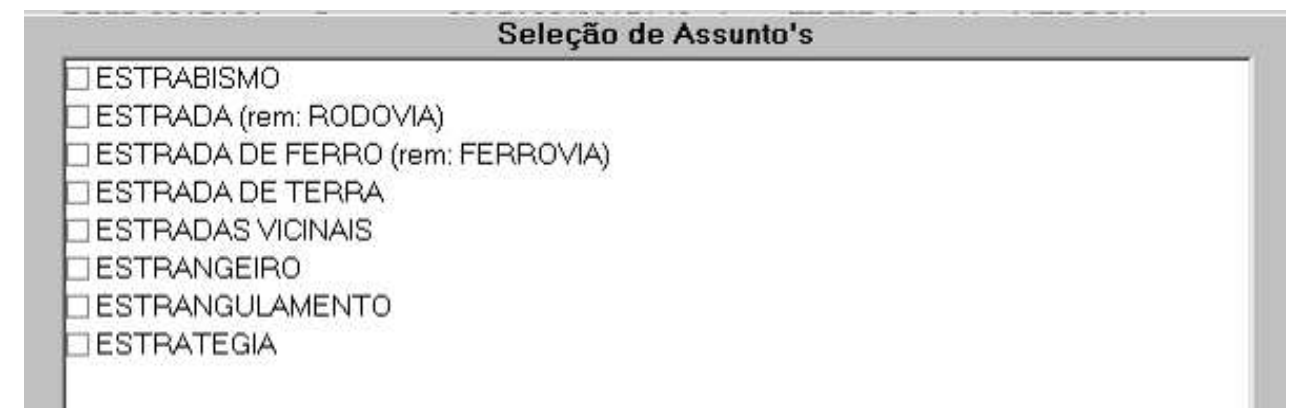

Figura 16: Amostra de termos iniciados com "estra" 
Além da lista de termos simplesmente dispostos em ordem alfabética, no caso de dúvida, é possível consultar os detalhes do termo, isto é, suas relações, hierarquias de assuntos, notas explicativas e outros recursos que ajudam a decidir pela inclusão ou não do termo. Na Figura 17, exemplo de como é possível visualizar os detalhes de um termo de forma a auxiliar no processo de indexação:

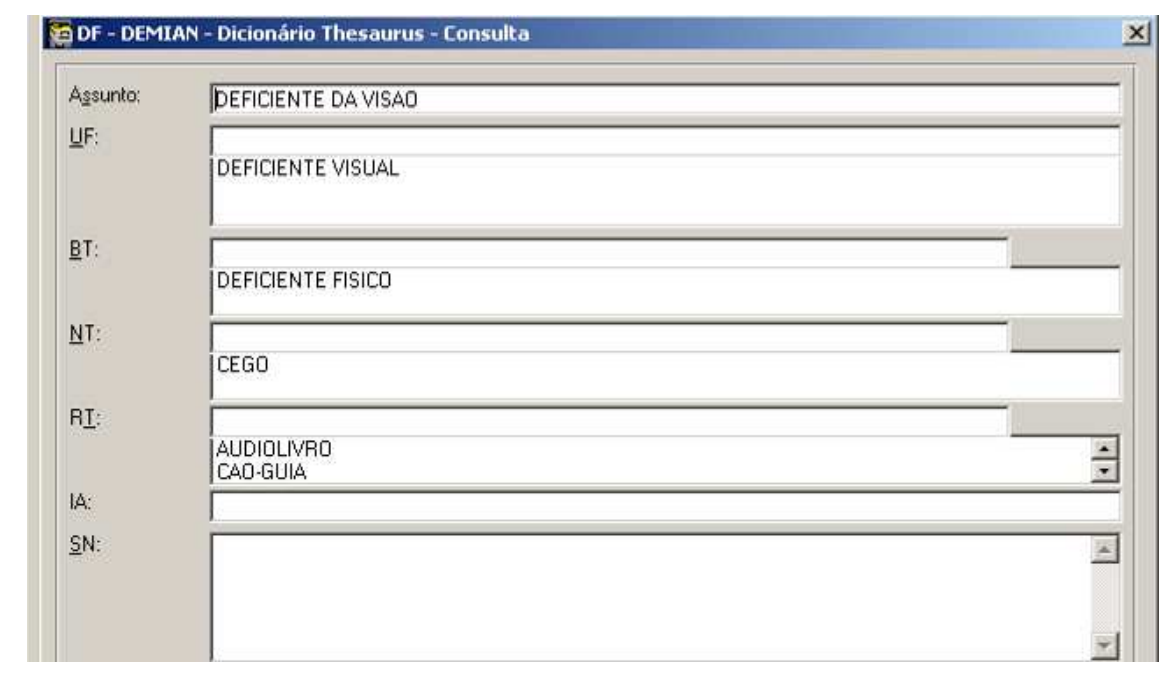

Figura 17: Exemplo de termo detalhado

Na Figura 17:

- UF (used for): termo não utilizado. Neste exemplo, deverá ser usado "deficiente da visão" ao invés de "deficiente visual". Este recurso faz o controle de sinônimos, no qual são geradas remissivas;

- BT (board term): termo mais amplo, hierarquicamente superior. No caso, "deficiente físico" é hierarquicamente superior, ou seja, deficiência visual é um tipo de deficiência física;

- NT (narrow term): termo específico. No exemplo, "cego" é um tipo de deficiência da visão, já que nem todo deficiente da visão é cego;

- RT (related term): termo relacionado. Usar estes termos para assuntos relacionados. Este recurso também ajuda a identificar em quais situações usar o termo em questão; 
- SN (scope note): notas de escopo. Pequeno texto esclarecedor do termo. Utilizada para indicar o conceito do termo (a maioria em termos técnicos) ou em quais situações ele deverá ser usado.

\subsubsection{TERMOS COM BAIXA DEMANDA}

Como dito anteriormente, há termos cuja utilidade e importância são questionáveis. Existe a necessidade de uma revisão e atualização em todo o Thesaurus. Enquanto a revisão não é feita, costuma-se deparar com termos, como os da Tabela 3:

Tabela 3 - Exemplos de termos pouco utilizados

\begin{tabular}{|c|c|c|c|c|}
\hline \multirow{2}{*}{$\begin{array}{l}\text { TERMO } \\
\text { DUGONG }\end{array}$} & \multirow{6}{*}{$\begin{array}{l}\text { O QUE SIGNIFICA* } \\
\text { Espécie de mamífero } \\
\text { marinho parecido com } \\
\text { golfinho que habita os } \\
\text { oceanos İndico e } \\
\text { Pacífico. }\end{array}$} & \multicolumn{2}{|c|}{$\begin{array}{l}\text { QUANTAS } \\
\text { VEZES O } \\
\text { TERMO FOI } \\
\text { USADO }\end{array}$} & \multirow{2}{*}{$\begin{array}{l}\text { USADO } \\
\text { PELA } \\
\text { ÚLTIMA } \\
\text { VEZ } \\
1984\end{array}$} \\
\hline & & RJ & 1 & \\
\hline & & SP & 0 & - \\
\hline & & DF & 0 & - \\
\hline & & $\mathrm{BH}$ & 0 & - \\
\hline & & $\mathrm{PE}$ & 0 & - \\
\hline \multirow[t]{5}{*}{ HMONG } & \multirow{5}{*}{$\begin{array}{l}\text { Etnia que habita o norte } \\
\text { do Vietnã, Tailândia e } \\
\text { Laos. Também é um dos } \\
\text { dialetos falados por eles. }\end{array}$} & RJ & 1 & 1979 \\
\hline & & SP & 0 & - \\
\hline & & $\mathrm{DF}$ & 0 & - \\
\hline & & $\mathrm{BH}$ & 0 & - \\
\hline & & $\mathrm{PE}$ & 0 & $\frac{7}{2}$ \\
\hline \multirow[t]{5}{*}{ KHAT } & \multirow{5}{*}{$\begin{array}{l}\text { Planta nativa da África e } \\
\text { Península Arábica que } \\
\text { contém substâncias } \\
\text { alucinógenas, proibida } \\
\text { em diversos países. }\end{array}$} & $\mathrm{RJ}$ & 4 & 1993 \\
\hline & & SP & 0 & - \\
\hline & & $\mathrm{DF}$ & 0 & - \\
\hline & & $\mathrm{BH}$ & 0 & - \\
\hline & & $\mathrm{PE}$ & 0 & 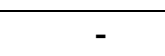 \\
\hline \multirow[t]{5}{*}{ MACROGLOBULINEMIA } & \multirow{5}{*}{$\begin{array}{l}\text { Distúrbio no qual os } \\
\text { plasmócitos produzem } \\
\text { uma quantidade } \\
\text { excessiva de anticorpos } \\
\text { grandes que se } \\
\text { acumulam no sangue. }\end{array}$} & RJ & 1 & 1980 \\
\hline & & SP & 0 & - \\
\hline & & $\mathrm{DF}$ & 0 & - \\
\hline & & $\mathrm{BH}$ & 0 & - \\
\hline & & $\mathrm{PE}$ & 0 & - \\
\hline \multirow[t]{5}{*}{ METODO DE BILLINGS } & \multirow{5}{*}{$\begin{array}{l}\text { Método contraceptivo, } \\
\text { em que a mulher calcula } \\
\text { o seu período fértil na } \\
\text { menstruação. }\end{array}$} & RJ & 5 & 1980 \\
\hline & & SP & 0 & \\
\hline & & DF & 1 & 1997 \\
\hline & & $\mathrm{BH}$ & 0 & \\
\hline & & $\mathrm{PE}$ & 1 & 1996 \\
\hline \multirow[t]{3}{*}{ PERIPATUS } & \multirow{3}{*}{$\begin{array}{l}\text { Espécie de animal } \\
\text { carnívoro parecido com } \\
\text { a lacraia, encontrado na }\end{array}$} & RJ & 3 & 1991 \\
\hline & & SP & 0 & - \\
\hline & & $\mathrm{D}$ & 0 & \\
\hline
\end{tabular}




\begin{tabular}{|c|c|c|c|c|}
\hline & \multirow[t]{2}{*}{ Índia e América Central. } & $\mathrm{BH}$ & 0 & - \\
\hline & & PE & 0 & - \\
\hline \multirow[t]{5}{*}{ PIQUIRA (CAVALO) } & \multirow{5}{*}{$\begin{array}{l}\text { Raça de cavalo de } \\
\text { pequeno porte. }\end{array}$} & RJ & 2 & 1991 \\
\hline & & SP & 0 & - \\
\hline & & DF & 0 & - \\
\hline & & $\mathrm{BH}$ & 0 & - \\
\hline & & $\mathrm{PE}$ & 0 & - \\
\hline \multirow{5}{*}{ TEATRO DO ABSURDO } & \multirow{5}{*}{$\begin{array}{l}\text { Forma do teatro } \\
\text { moderno que utiliza } \\
\text { elementos chocantes do } \\
\text { ilógico, com o objetivo de } \\
\text { reproduzir diretamente a } \\
\text { falta de soluções em que } \\
\text { estão imersos o homem } \\
\text { e sociedade. }\end{array}$} & RJ & 5 & 1988 \\
\hline & & SP & 0 & - \\
\hline & & DF & 1 & 1997 \\
\hline & & $\mathrm{BH}$ & 0 & - \\
\hline & & PE & 2 & 1989 \\
\hline
\end{tabular}

*Fontes: Wikipedia; Portal Farmácia; Britannica.com

Não se sabe ao certo quais e quantos termos possuem pouca utilização. Os exemplos foram escolhidos aleatoriamente e executada a pesquisa em todos os Cedocs, para se saber se o problema é apenas da praça Brasília. Constatou-se que a maioria destes termos foi utilizada apenas no Rio e desaparecem pouco tempo depois.

É impossível saber se a não utilização é resultado da falta de conhecimento dos indexadores quanto ao assunto ou existência do termo. Para tal, seria necessário conversar com todos os indexadores que já trabalharam no Cedoc da TV Globo desde sua criação, rastrear toda a base de dados para verificar quais documentos abordaram o assunto e descobrir a data na qual os termos foram criados. Além de inviável, não é o objetivo deste estudo.

\subsubsection{DEFICIÊNCIA DE TERMOS}

Outro problema comumente encontrado durante o trabalho de indexação é a falta de termos que indiquem assuntos relevantes de forma direta, sem a necessidade de cruzamento entre termos. Às vezes é feita uma negociação com o Cedoc Rio para se pedir a inclusão de termos importantes. Exemplo: a palavra "poeira", para Brasília é muito importante, pois há muitas matérias sobre o assunto, são cidades cobertas por ela. Outro exemplo é a palavra "plenário", que não existia no Thesaurus. Foi necessário explicar sua necessidade até conseguir a adesão do 
Rio. Existem outros problemas frente aos quais sempre há a necessidade de negociar com a matriz, onde são feitas as inclusões e alterações.

$\mathrm{Na}$ Tabela 4, encontram-se alguns exemplos de termos importantes que ainda não foram inseridos no Thesaurus:

Tabela 4 - Exemplos de termos que não constam no Thesaurus

\begin{tabular}{|l|l|}
\hline TERMO NECESSÁRIO & ALTERNATIVA PARA COBRIR O ASSUNTO \\
\hline ENXURRADA & $\begin{array}{l}\text { Usar o termo ENCHENTE. Pode causar confusão, pois } \\
\text { há várias imagens de enxurrada sem caracterizar } \\
\text { necessariamente uma enchente. }\end{array}$ \\
\hline SAUDE BUCAL & $\begin{array}{l}\text { Fazer o cruzamento dos termos BOCA, PREVENCAO } \\
\text { A DOENCA e SAUDE. }\end{array}$ \\
\hline LICITACAO & $\begin{array}{l}\text { Além de indicar o órgão que realizou a licitação, é } \\
\text { necessário cruzar os termos EMPRESA, CONTRATO } \\
\text { DE TRABALHO e GOVERNO. } \\
\text { Também é necessário indicar o assunto, por exemplo: } \\
\text { no assunto "licitaçáo para a construção de ciclovias" } \\
\text { também é necessário indicar os termos CICLOVIA e } \\
\text { CONSTRUCAO. }\end{array}$ \\
\hline MULTA & $\begin{array}{l}\text { O termo MULTA remete para o termo PUNICAO. Mas } \\
\text { nem toda punição é aplicada em forma de multa. }\end{array}$ \\
\hline IMPUNIDADE & $\begin{array}{l}\text { Cruzar os termos PUNICAO, FALTA(AUSENCIA), } \\
\text { JULGAMENTO e CRIME. }\end{array}$ \\
\hline TOMBAMENTO OU & $\begin{array}{l}\text { Existe o termo TOMBAMENTO apenas no sentido de } \\
\text { se proteger um patrimônio de valor artístico, histórico } \\
\text { etc. Para acidente, usar apenas ACIDENTE } \\
\text { AUTOMOBILISTICO. Caso seja realmente importante } \\
\text { O acidente no qual o veículo tombou ou capotou, } \\
\text { indicar na sinopse para que possa ser recuperado pelo } \\
\text { vocabulário livre. }\end{array}$ \\
\hline ENTORNO & $\begin{array}{l}\text { O termo ENTORNO remete para SUBURBIO. Há aqui } \\
\text { uma confusão causada por diferenças regionais. O } \\
\text { chamado entorno do Rio é composto por bairros } \\
\text { periféricos, chamados genericamente de subúrbio. Já o } \\
\text { chamado entorno de Brasília é composto por 12 } \\
\text { cidades autônomas nos estados de Goiás e Minas } \\
\text { Gerais. É errado dizer, por exemplo, que Luziânia é } \\
\text { subúrbio de Brasília. Por subúrbio de Brasília, entende- } \\
\text { se as cidades-satélite, situadas no perímetro do Distrito } \\
\text { Federal. Quando a matéria se tratar das cidades do } \\
\text { entorno de Brasília, usar o termo SUBURBIO. Em } \\
\text { matérias que abordem as cidades-satélite de um modo } \\
\text { geral, utilizar simplesmente o termo BRASILIA }\end{array}$ \\
\hline
\end{tabular}


(CIDADE). Se a matéria for sobre alguma cidadesatélite em específico, já existe identidade cadastrada do respectivo local no VC.

\subsubsection{OUTROS CASOS}

Alguns casos merecem a atenção e exigem percepção do indexador. Para se indexar uma matéria sobre carros, por exemplo, o Thesaurus conta com os termos VEICULO e AUTOMOVEL. É necessário que o indexador saiba que ambos não são sinônimos, e sim automóvel é apenas um tipo de veículo. Por veículo, entende-se qualquer meio de transporte: caminhão, avião, ônibus, bicicleta, etc.

Da mesma forma, os termos ACIDENTE e ACIDENTE AUTOMOBILISTICO merecem cuidado em sua utilização. Para acidentes envolvendo veículos motorizados (carro, ônibus, caminhão), obviamente utilizar o segundo termo. Quando o acidente acontecer durante uma apresentação de circo, por exemplo, fazer o cruzamento ACIDENTE e CIRCO.

Há casos de termos que são inseridos no Thesaurus sem que haja certo cuidado quanto ao seu significado ou conhecimento profundo. Por exemplo, o termo TAJ MAHAL(TEMPLO), famoso monumento indiano, encontra-se no VC. Apesar de o Thesaurus indicar que o Taj Mahal é um templo, o monumento é apenas um mausoléu (túmulo), não existindo qualquer atividade religiosa no local.

\subsubsection{SUGESTÕES E CRITÉRIOS}

Normalmente as atualizações no Thesaurus feitas pelo Cedoc Rio e repassadas às outras praças são a inclusão de termos de pouquíssima importância (por exemplo, uma raça de macacos), aumentando a quantidade de termos sem o devido cuidado quanto à qualidade. Existe a necessidade de se flexibilizar a negociação para inclusão de termos importantes para atender às demandas como os casos expostos. Abaixo, algumas sugestões de novos procedimentos de inclusão e exclusão a serem adotados:

- Aumentar a comunicação entre os Cedocs das cinco praças; 
- Excluir termos que foram utilizados menos de dez vezes desde a criação do sistema de recuperação do Cedoc;

- Incluir termos de assuntos nos quais seja necessário o cruzamento de termos muito genéricos;

- Verificar se o termo a ser inserido possui muitos documentos que abordam o assunto;

- Aumentar a quantidade de notas de escopo nos termos e jargões de áreas específicas.

\subsection{O DICIONÁRIO DE IDENTIDADES}

Outro recurso utilizado no Vocabulário Controlado é o Dicionário de Identidades. Diante da impossibilidade de se incluir nomes próprios no Thesaurus, criou-se este recurso, no qual são incluídos nomes de pessoas famosas (atores, políticos, jogadores, etc.), lugares, siglas, casos que geraram grande repercussão (escândalos políticos, operações da Polícia Federal, acidentes, guerras), bandas, eventos esportivos de grande porte (Campeonato Brasileiro de Futebol, Olimpíadas etc.), grandes empresas e qualquer outro tipo de item que seja considerado relevante o suficiente para ser incluído no dicionário de identidades em questão.

O Dicionário de Identidades, devido à sua característica regional, não possui padronização nas praças. Sua atualização é independente. Mas é recomendável que, antes de se criar uma identidade regional, consultar-se a matriz do Rio para verificar se tal identidade já foi criada. Por exemplo: no Cedoc Brasília é possível encontrar o termo CAJE, sigla para Centro de Atendimento Juvenil Especializado, local de internação para menores infratores do Distrito Federal. Por ser uma instituição existente somente em Brasília, por sua importância e constantes ocorrências no noticiário, este termo foi incluído no Dicionário de Identidades e não seria encontrado na praça de Recife, por exemplo. Até 15 de abril de 2009 havia 7681 entidades cadastradas no Dicionário de Identidades. 


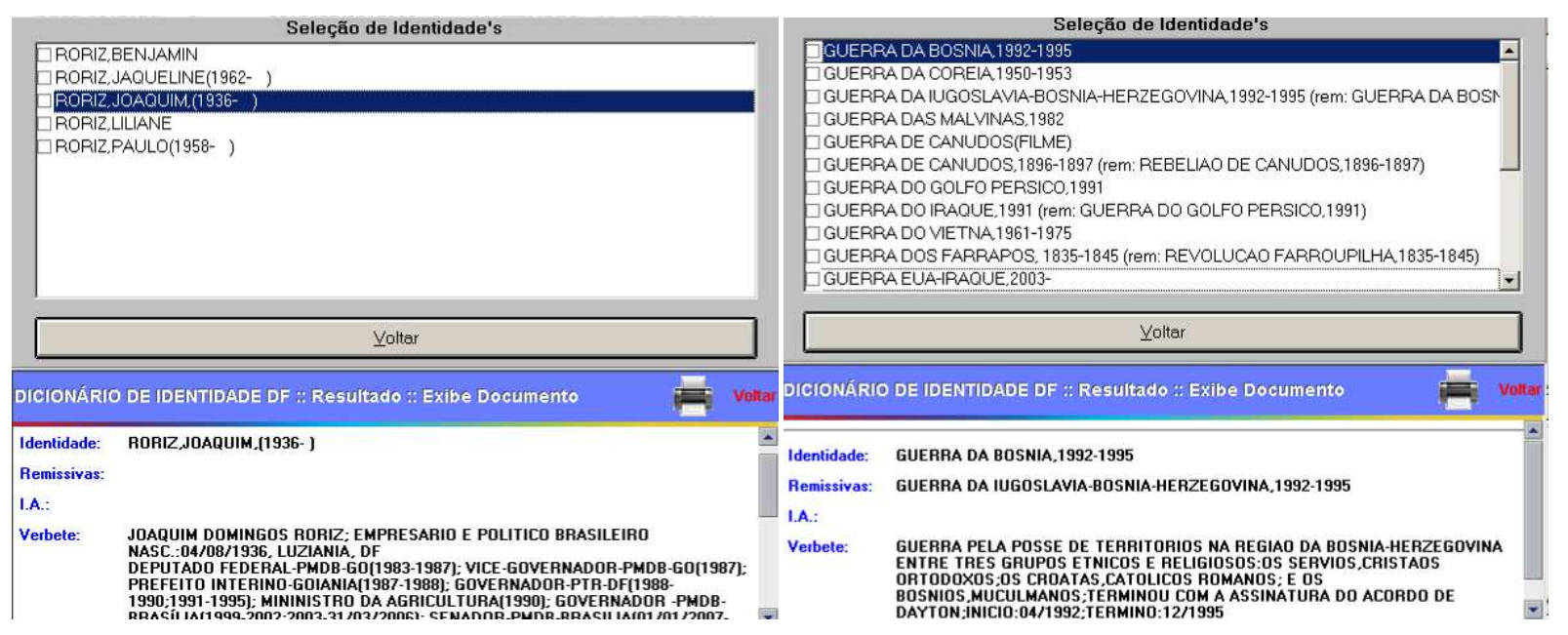

Figura 18: Dois exemplos de entradas do Dicionário de Identidades. Políticos e guerras

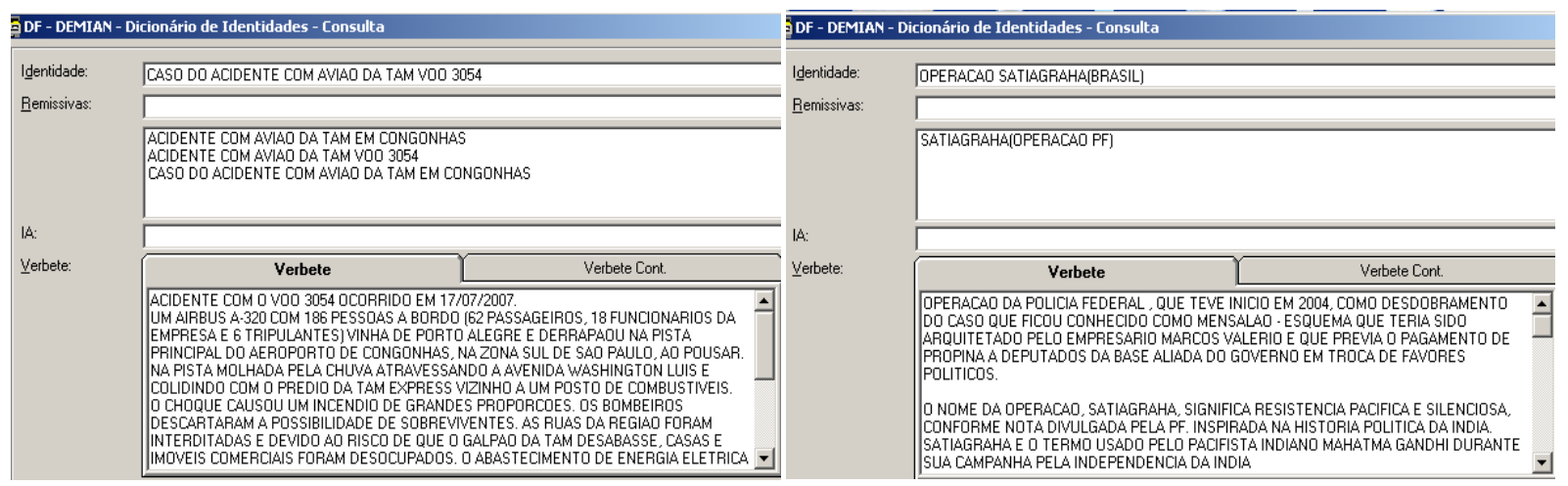

Figura 19: Dois exemplos de casos de grande repercussão

Em cada caso, é necessário fornecer, no verbete, informações da entidade que está sendo criada, como se fosse uma mini-enciclopédia. Por exemplo: trajetória política de uma autoridade, histórico de uma CPI, etc. Às vezes isto não é necessário, por exemplo, quando se inclui nomes de cidades ou países.

Quando uma nova identidade é criada, é preciso fazer a reindexação de todo o material sobre o assunto. Um dos exemplos mais recentes é o caso da Vila Estrutural, invasão às margens de uma rodovia no Distrito Federal que foi regularizada e ganhou o status de cidade-satélite. Depois de ter se tornado uma das regiões administrativas do DF, sua identidade foi criada e todo o material reindexado. Até então, matérias sobre a até então chamada vila Estrutural eram recuperadas com os termos INVASAO e VIA ESTRUTURAL. Após a criação do termo ESTRUTURAL(CIDADE), mais de 400 matérias foram reindexadas. 
Também é necessário reindexar o material quando há a criação de um novo termo no Thesaurus. Termos criados recentemente, como LAN HOUSE e TELEFONE CELULAR fizeram com que se reindexasse todas as matérias que tratam destes assuntos.

Os termos do Dicionário de Identidade e do Thesaurus possuem o mesmo peso durante a pesquisa, ou seja, o sistema de busca não estabelece prioridades.

\section{A PESQUISA}

Todo o material arquivado no Cedoc tem sua razão de existir. Além da preservação patrimonial, há outro motivo: o processo de elaboração de sinopse, indexação e os demais serviços foram feitos para que os documentos possam ser recuperados quando solicitados. Este é o objetivo da indexação, principal atividade desenvolvida pelos bibliotecários do Cedoc. Mas para quem são recuperados estes materiais? Quem é o principal usuário dos serviços prestados pelo Cedoc?

A Central Globo de Jornalismo responde pela quase totalidade das solicitações de pesquisas realizadas. Os principais usuários são repórteres, apresentadores, produtores e outras pessoas envolvidas no jornalismo, que todos os dias solicitam dezenas de itens de pesquisa. A seguir, os detalhes deste processo.

\subsection{O PEDIDO}

Ao se produzir uma matéria sobre a redução da taxa de juros da economia, é comum ilustrar a reportagem com belas fachadas do Banco Central do Brasil, pessoas contando dinheiro, operários na construção civil, indústrias funcionando e quaisquer imagens que tenham relação com o crescimento da economia. Este é um dos incontáveis exemplos de matérias produzidas com imagens fornecidas pelo Cedoc Brasília.

Boa parte das imagens exibidas nos telejornais da TV Globo diariamente é de material indexado pelos bibliotecários e recuperado a pedido do produtor responsável pela reportagem. É muito dispendioso, demorado e nada eficiente se 
escalar cinegrafistas para produzir imagens novas a cada reportagem. Por isso, é de grande importância que o Cedoc forneça imagens que serão usadas pela produção. Alguns exemplos de pedidos estão relacionados na Figura 20.

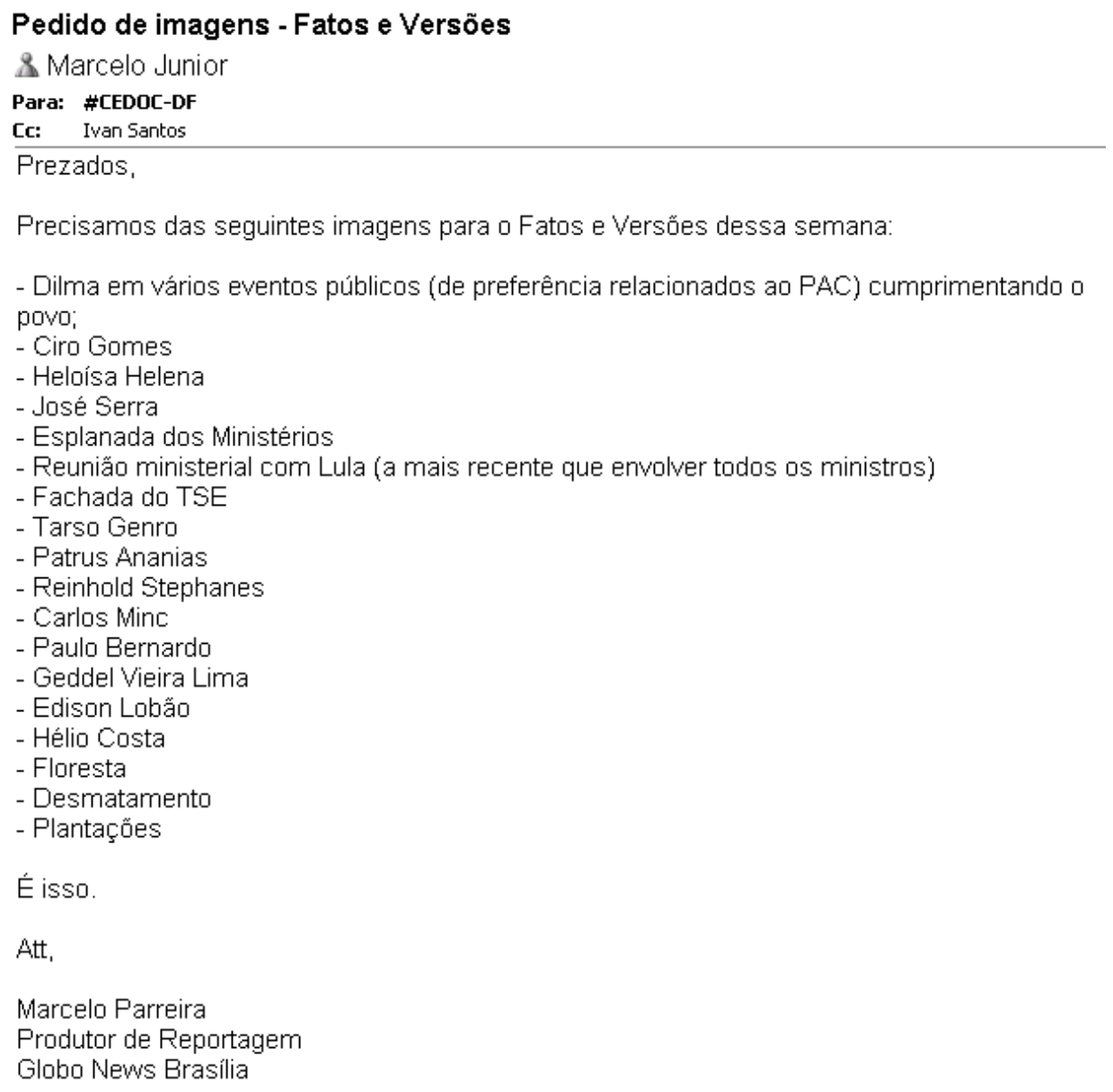

Figura 20: Exemplo de pedido feito ao Cedoc Brasília

Este é um pedido simples, no qual quase todos os itens solicitados se encontram devidamente indexados de forma que não seja necessário fazer cruzamento de termos, ou seja, para cada item há um termo exato correspondente.

Há pedidos que são um pouco mais elaborados. Em alguns itens é necessário fazer cruzamento de termos para recuperar a imagem solicitada. Algumas pesquisas levam poucos segundos. Outros pedidos podem levar horas, dependendo do nível de especificidade e urgência. Na Figura 21, outro exemplo de pedido. 


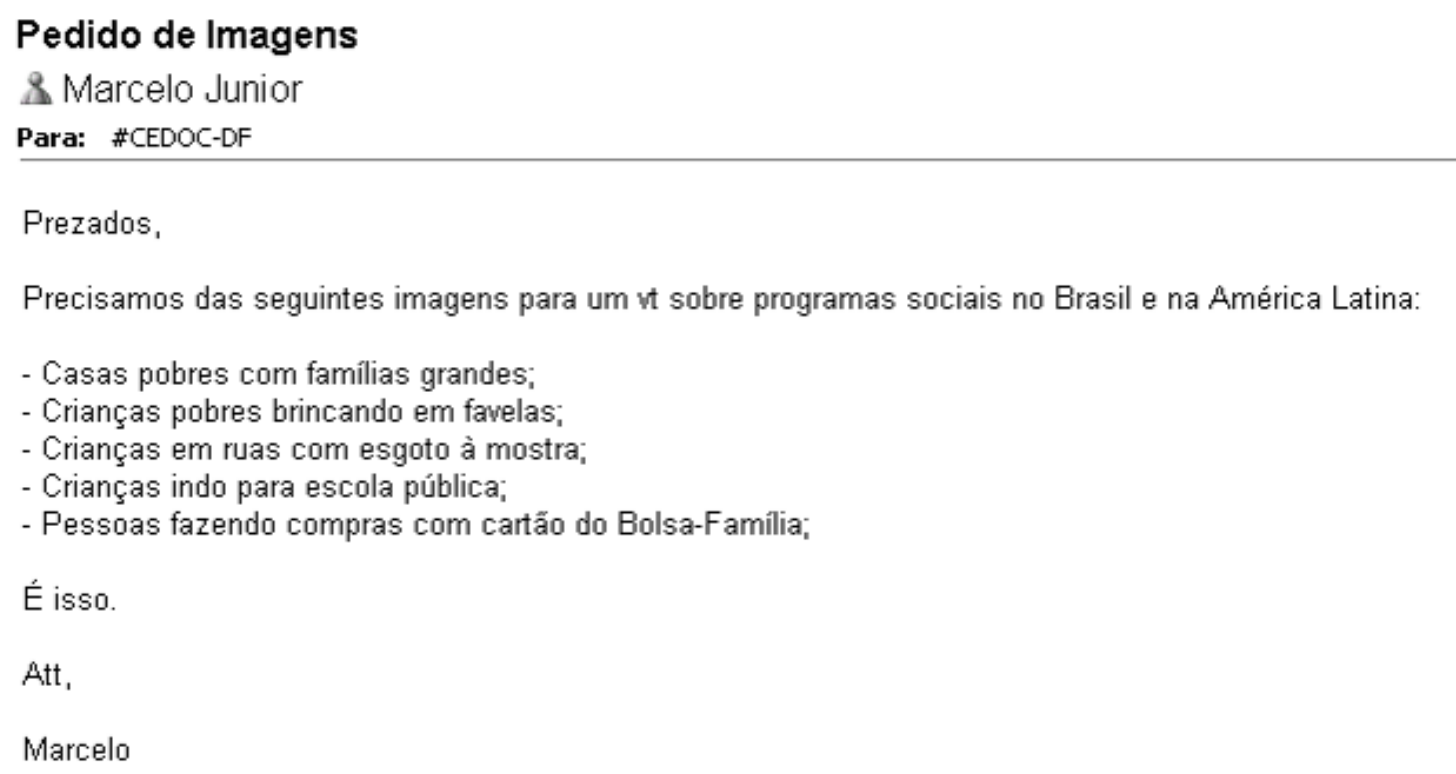

Figura 21: Pedido de imagens feito ao Cedoc

O atendimento a pesquisas é um processo que exige certas práticas de referência. Muitas vezes o usuário não sabe o que quer e às vezes acaba fazendo pedidos engraçados ou bizarros, virando motivo de piada entre os funcionários do Cedoc. Há relatos de pedidos como:

- imagem de uma vaca subindo um morro, e num dado momento ela para e olha pra trás;

- imagens de primos se abraçando;

- imagens aéreas feitas de cima;

- imagens de plantação de agricultura;

- imagens da pré-história.

O pedido da imagem da vaca foi recusado, por ser impossível se indicar no documento esta ação. Quanto ao segundo pedido, simplesmente olhando duas pessoas se abraçando, obviamente é impossível saber se são primos, irmãos, amigos, namorados, etc. Os dois pedidos seguintes são apenas problemas de redundância, não sendo necessariamente pedidos bizarros, mas não deixaram de entrar para as histórias engraçadas do Cedoc. Quanto às imagens da pré-história, é um caso típico de usuário que não sabe o que quer e foi preciso fazer a entrevista de referência. A pessoa precisava de imagens de fósseis, esqueleto de dinossauro exposto em museu, sítio arqueológico ou pinturas rupestres? Depois de refinar a 
pergunta, o usuário finalmente informou o que queria e foi possível encontrar a imagem solicitada.

\subsection{PESQUISA CONTROLADA E PESQUISA LIVRE}

Feito o pedido, a próxima fase é a pesquisa. Depois de devidamente anotados no sistema os itens a serem recuperados, o pesquisador estabelece a melhor estratégia de busca a ser feita. Para isto, dispõe de duas opções: pesquisa controlada e pesquisa livre.

A pesquisa controlada é aquela na qual se usa linguagem documentária, ou seja, o Vocabulário Controlado (VC) que, como dito anteriormente, é composto pelo Thesaurus e pelo Dicionário de Identidades que se complementam. Nela há o controle de sinônimos e homônimos e o resultado é exatamente o que o pesquisador precisa.

A pesquisa livre é usada quando não é possível encontrar o item através do VC, normalmente para itens que não fazem parte do assunto principal ou não existem termos para representá-los na indexação. O sistema busca qualquer palavra inserida, mas não consegue buscar expressões exatas.

Recentemente um jornalista solicitou a imagem de uma caminhonete da Polícia Militar do DF, da marca Mitsubishi, que era objeto de irregularidades que estavam sendo investigadas. Até então ninguém descrevia na sinopse o tipo ou marca de viatura policial. É usada somente a palavra "viatura" na sinopse e o termo CARRO DE POLICIA na indexação. Diante da impossibilidade de encontrar a imagem a tempo, foi necessário que um cinegrafista filmasse uma caminhonete qualquer do mesmo modelo para a imagem ser usada como exemplo. Se a marca ou tipo de viatura da polícia estivesse descrito na sinopse, com certeza a imagem teria sido encontrada pela pesquisa livre.

Outro exemplo de pesquisa solicitada que é impossível encontrar através do VC é a seguinte: um jornalista precisou da imagem do Presidente Lula vestindo uma jaqueta bege, para ser usada numa reportagem sobre o pólo de modas do Guará. A jaqueta do presidente, entre outras roupas, é feita por uma costureira de lá. Como é 
impossível pesquisar pela cor ou modelo da roupa por se julgar irrelevantes (a não ser que a roupa seja o assunto principal), foi preciso improvisar. A jaqueta possui um brasão da República e é um traje informal, usada em ocasiões onde há contato com o povo. A pesquisa então foi feita nesse sentido e a imagem finalmente foi encontrada.

Ainda como pesquisa livre, o seguinte exemplo também é válido: um jornalista solicitou o trecho do depoimento do ex-deputado Roberto Jefferson dizendo que o Presidente Lula é inocente no caso do mensalão. Como se trata de uma fala importante, a pessoa que fez a decupagem incluiu esta frase na sinopse. Esta frase somente poderia ser recuperada através do vocabulário livre. Para tanto, foi feita a busca com as palavras "Lula" e "inocente". O documento recuperado mostra as palavras buscadas em vermelho, como no exemplo da Figura 22.

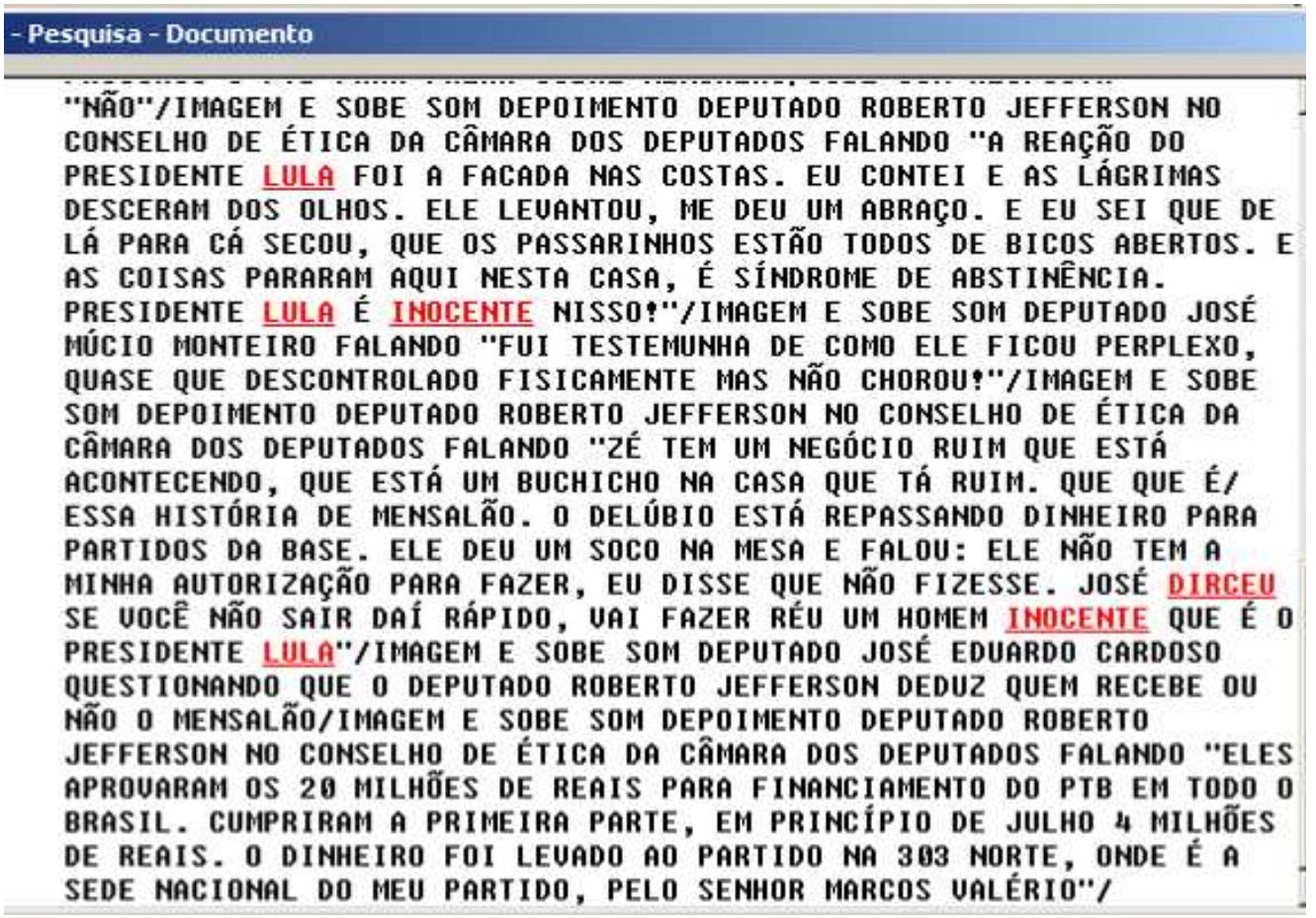

Figura 22: Documento recuperado através da pesquisa livre

\subsection{O PROCEDIMENTO RESUMIDO}

O trabalho desenvolvido no Cedoc segue uma rotina: inclusão no acervo, atendimento a pedidos, pesquisa e edição de imagens. Nesta última fase, as imagens selecionadas são copiadas pelo editor e disponibilizadas para o jornalista. 
Na Figura 23, o fluxograma resumido do procedimento adotado no Cedoc Brasília, nos mesmos moldes das demais praças.

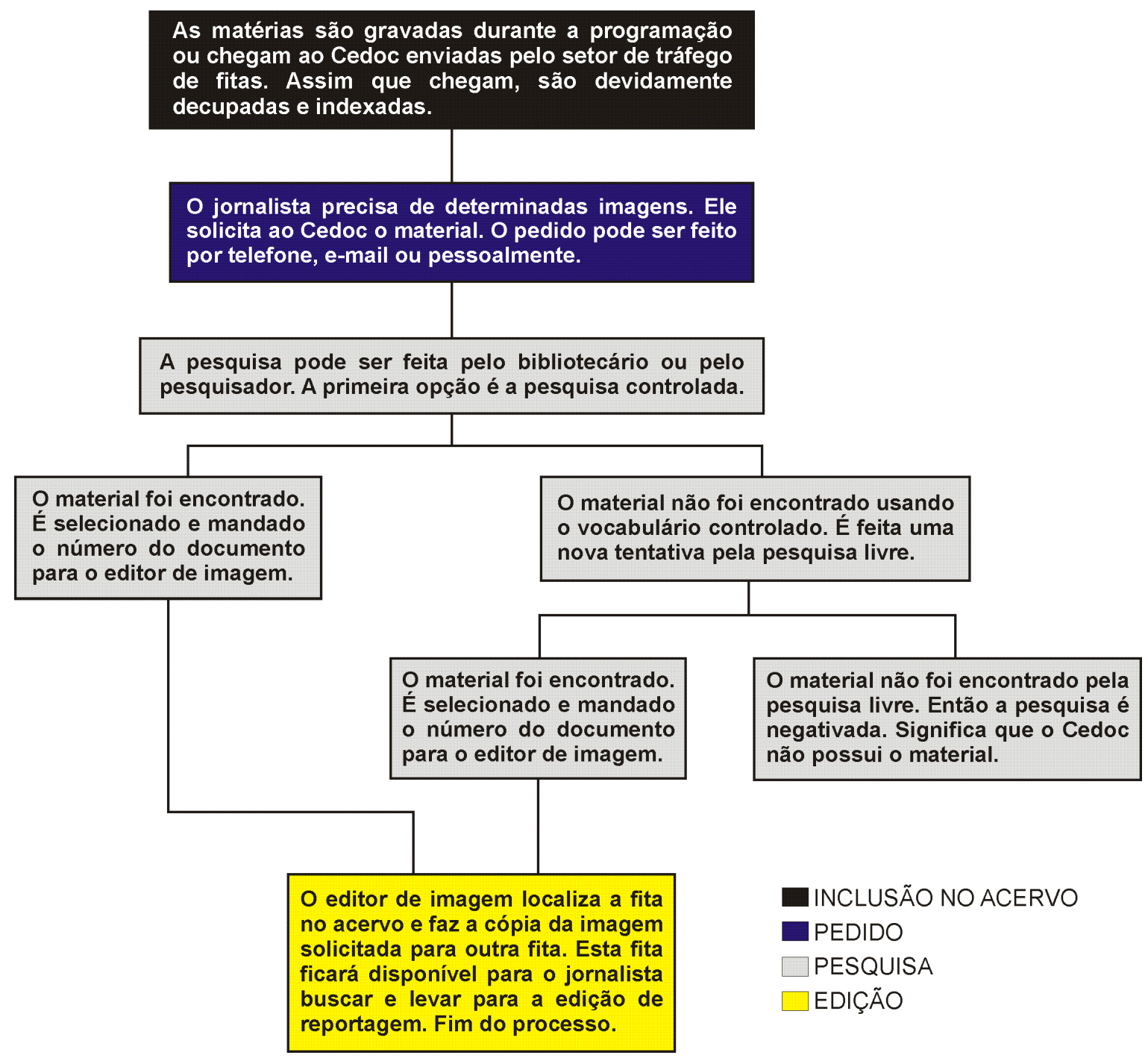

Figura 23: Resumo do procedimento de pesquisa de imagem

\subsection{PONTOS FORTES E PONTOS FRACOS DO SISTEMA}

O sistema de gerenciamento do acervo e buscas foi desenvolvido pela própria emissora. Não se trata de um software comercial. Ele é considerado de resposta rápida, confiável e de fácil compreensão e execução, além de possuir supervisão técnica a todo momento, com muitas atualizações online. Apresenta divisão por 
classes (50, 51, 53 e 55, como mostrado anteriormente) que ajuda nas pesquisas, possibilidade de inserção de vídeos para visualização do material pelo usuário e interação entre as diversas praças, onde é possível ver e pesquisar suas bases de dados. Os pesquisadores não encontram grandes dificuldades no uso do sistema.

Apesar dos pontos fortes, o sistema também encontra certas limitações. A principal delas é a impossibilidade de se fazer pesquisas usando artigos, preposições ou números. A dificuldade está no fato de Brasília possuir muitas identificações por números: Escola Classe 05; QI 25; quadra 310 norte, entre outros. Há também grande material político no qual se usa muitos termos numéricos (MP 244; PL 42/09, etc). Além disso, os materiais de divulgação cultural possuem nomes de bandas e peças teatrais que são confusos: "É só!", "Por aí vai", "Banda 80", "Esquema 6", etc. Como a maioria deste material não está inserida no Dicionário de Identidades por ser de pouca expressão, é difícil encontrá-lo.

O sistema também não possui corretor ortográfico, como os usados em softwares comuns de edição de texto.

\subsection{PRECISÃO E REVOCAÇÃO}

Quando se pretende avaliar uma base de dados, um dos itens a serem observados, segundo Rodrigues e Silva (2007), é a recuperação da informação. 0 êxito do usuário de localizar a informação desejada está relacionado com as etapas precedentes: indexação e armazenamento da informação.

A precisão é a relação entre a quantidade de itens relevantes que foram recuperados e o total de itens simplesmente recuperados. Já a revocação é a relação entre os itens relevantes recuperados e o total de itens relevantes existentes na base de dados.

O índice de precisão e de revocação depende, além da qualidade da indexação (exaustividade e especificidade), da estratégia de busca utilizada. Como exemplo, a seguinte pesquisa pode apresentar baixa precisão caso utilizada uma estratégia de busca equivocada: 
Objetivo: encontrar a imagem do Papa Bento XVI sendo apresentado aos fiéis após sua eleição.

Estratégia de busca usada: usar o termo BENTO XVI,PAPA que já se encontra inserido no Dicionário de Identidades.

O sistema recuperou 29 reportagens no Cedoc Brasília, nas quais o Papa Bento XVI é o assunto. Porém, a maioria das matérias é sobre sua visita ao Brasil. Assim, alterando a estratégia de busca para se pesquisar pelos termos PAPA e ELEICAO, o sistema recupera exatamente a matéria contendo a imagem em questão. O exemplo, apesar de bastante simples, serve para demonstrar que o sistema pode ser preciso ou não, como dito anteriormente, dependendo da estratégia de busca e experiência do pesquisador e indexador.

Este exemplo, utilizando a nova estratégia de busca, apresentou alta revocação, pelo fato de todos os itens relevantes existentes na base de dados do Cedoc Brasília terem sido recuperados. Abaixo, a sinopse de um dos documentos recuperados que contém a imagem buscada:

MULTIDÃO NA PRAÇA DE SÃO PEDRO NO VATICANO ESPERANDO O ANÚNCIO DO NOME DO NOVO PAPA/FUMAÇA BRANCA NA CHAMINÉ DA CAPELA/PESSOAS ASSISTINDO TELEVISÃO EM LOJAS DE ELETRODOMÉSTICO/POVO FALA/NOVO PAPA BENTO XVI SENDO APRESENTADO À MULTIDÃO NA PRAÇA DE SÃO PEDRO/MULHER APLAUDINDO NA FRENTE DA TV/SONORA DE LEONÍSIA BATISTA(DONA DE CASA)/MISSA NA MATRIZ DE SÃO EXPEDITO/PADRE ANUNCIANDO O NOME DO NOVO PAPA/SONORA DE PADRE EDUARDO VINÍCIUS DE LIMA (PROFESSOR DE TEOLOGIA)/SEMINARISTAS COMEMORANDO/ 


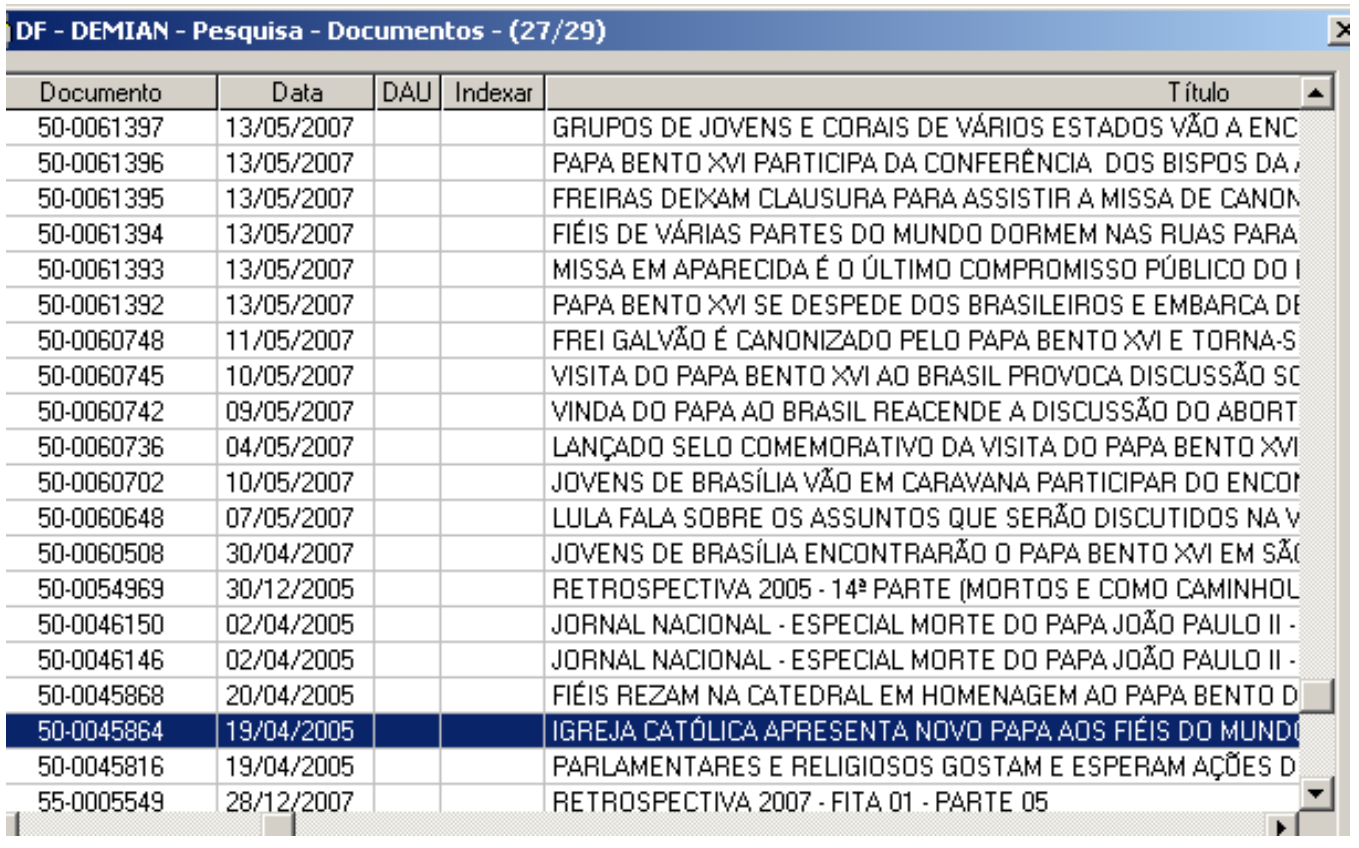

Figura 24: Lista de documentos recuperados

Outro exemplo de pesquisa cujo sucesso depende da estratégia de busca e da qualidade da indexação é o que se segue:

Objetivo: encontrar imagem de modelos desfilando no Capital Fashion Week.

Estratégia de busca usada: usar os termos DESFILE e MODA.

Foram recuperadas 38 reportagens, das quais somente 12 são sobre 0 evento buscado. Como este é um evento que só acontece em Brasília, o termo BRASILIA(CIDADE) foi inserido na estratégia de busca. Desta forma, foram recuperados 17 documentos, dos quais 10 atendem ao solicitado.

O terceiro exemplo se trata de um caso de imagem incomum, de situações nas quais as autoridades costumam se envolver: Ministros de Estado dançando, presidentes usando roupas diferentes, etc. Os termos que indiquem tal situação são inseridos obviamente conforme sua necessidade e a relevância da autoridade em questão.

Objetivo: encontrar imagem do Presidente Lula usando boné.

Estratégia de busca usada: buscar pelos termos SILVA,LUIZ INACIO LULA DA e BONE 
Por motivo óbvio, a busca não foi limitada utilizando-se apenas a identidade do Presidente, pois seriam encontrados milhares de documentos. Então, com 0 cruzamento dos dois termos foi possível recuperar 22 reportagens, das quais 19 contêm a imagem do Presidente usando diversos bonés, como os exemplos de trechos de sinopses abaixo:

- PRESIDENTE LULA COLOCANDO BONÉ DO MOVIMENTO DOS SEM UNIVERSIDADE (MSU)

- PRESIDENTE LULA VESTINDO O BONÉ DA ABIN

- PRESIDENTE LULA VESTINDO O BONÉ DO COMITÊ OLÍMPICO BRASILEIRO (COB)

- PRESIDENTE LUIS INÁCIO LULA DA SILVA COLOCANDO BONÉ DA CONTAG

- PRESIDENTE LULA COMENDO RAPADURA E VESTINDO BONÉ DO MST

- PRESIDENTE LULA COLOCANDO BONÉ DO MOVIMENTO GAY (GLBT)

- PRESIDENTE LULA VESTINDO UM BONÉ ESCRITO "HIP-HOP"

- PRESIDENTE LULA VESTINDO BONÉ E SUBINDO NO SKATE DE SANDRO DIAS NO PALÁCIO DO PLANALTO

- LULA VESTINDO O BONÉ DA UNE

\section{ESTATÍSTICAS}

Há um orçamento prévio e anual que é preciso ser cumprido. Todos os meses a central administrativa faz o balanço dos gastos. Caso haja necessidade de sair do que foi orçado, isto é negociado com a CGCom, que pode ceder ou não.

Ao final de cada mês, também é feita a prestação de contas à CGCom quanto aos trabalhos desempenhados pelo Cedoc. Uma planilha é apresentada, na qual são contabilizadas todas as atividades dos funcionários e estagiários quanto à inclusão de material, sinopses realizadas, indexações, pesquisas, cópia de material, etc. $\mathrm{Na}$ Figura 25, gráfico do desempenho das atividades do Cedoc Brasília. 


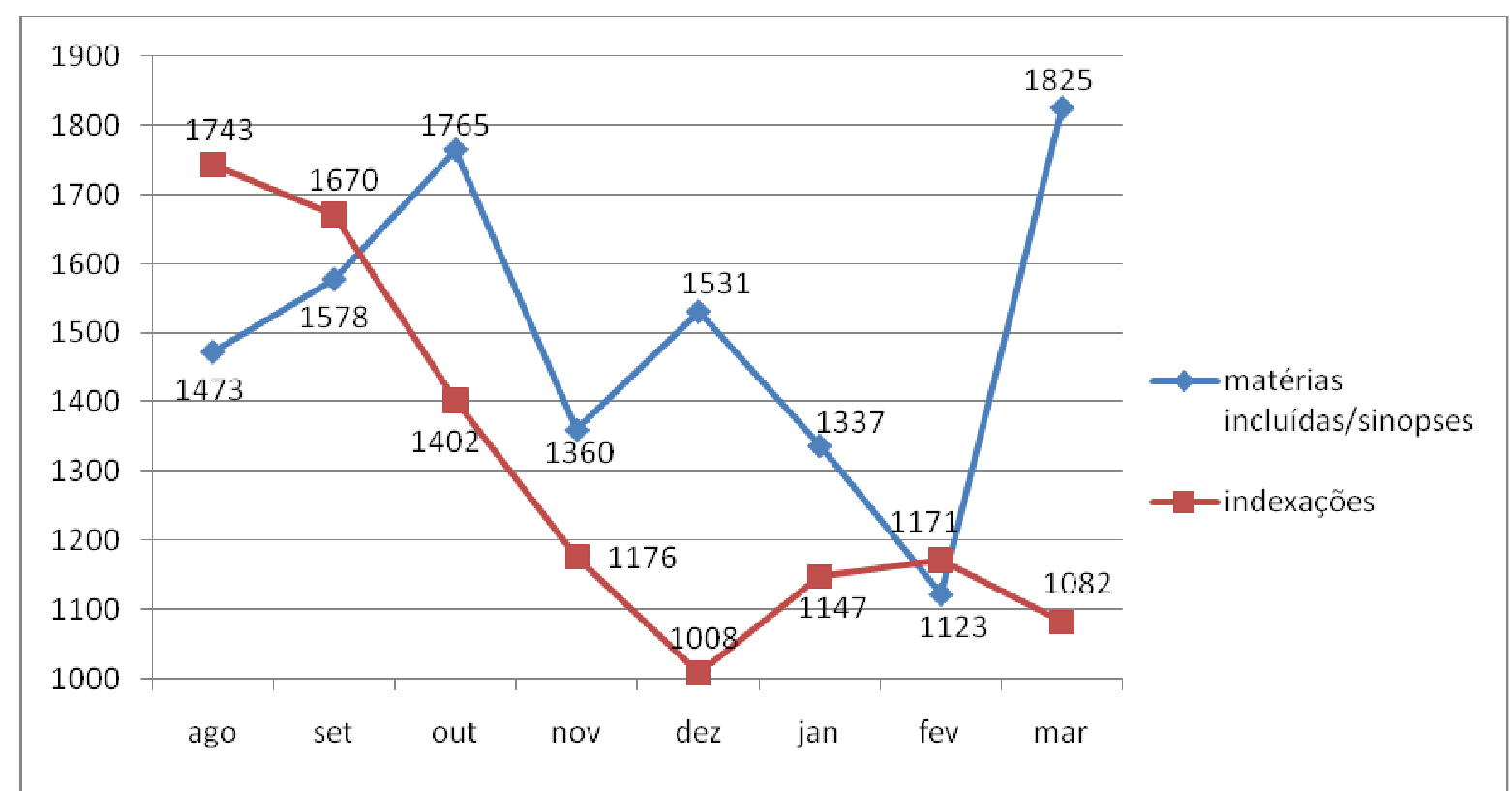

Figura 25: Relação entre matérias incluídas e indexações feitas (agosto de 2008 a março de 2009)

O gráfico da relação entre as matérias incluídas e indexações feitas nos permite inferir que o número de indexações é quase sempre menor. Isto se explica pelo fato do Cedoc Brasília possuir duas pessoas que fazem a indexação e cinco na elaboração de sinopses.

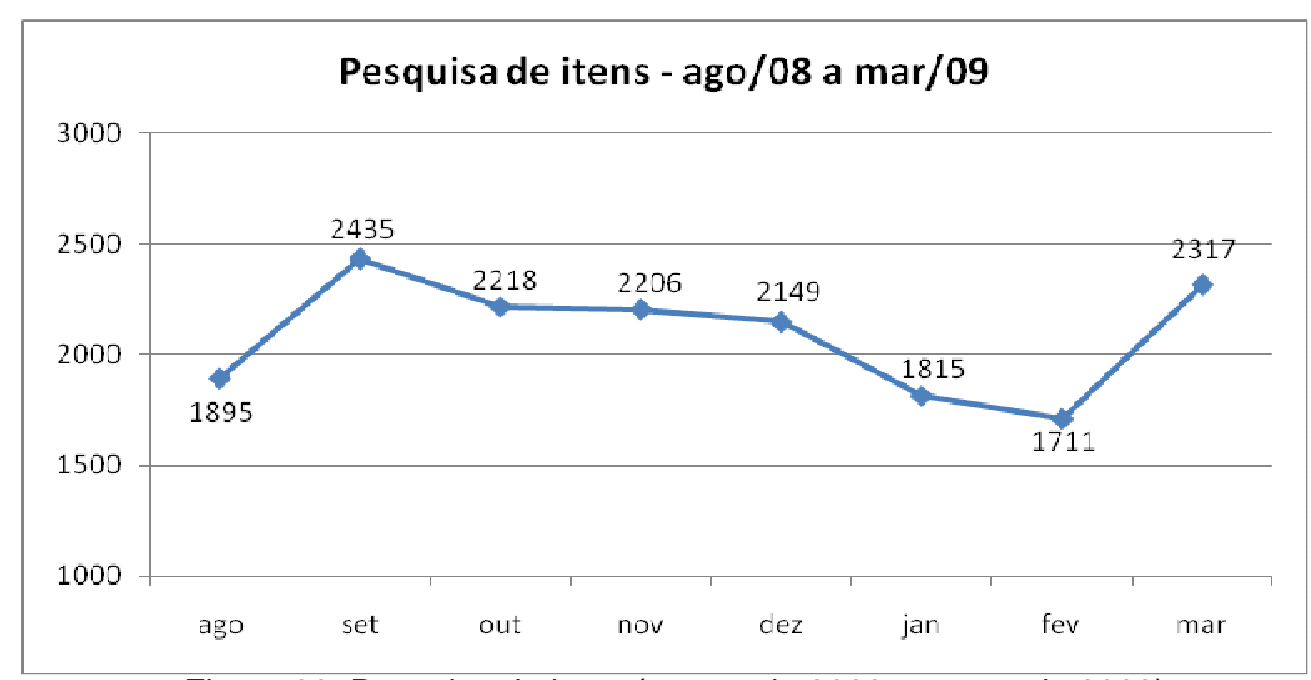

Figura 26: Pesquisa de itens (agosto de 2008 a março de 2009) 
São pesquisados, por dia, cerca de 80 a 90 itens. Cada pesquisa contém vários itens, ou seja, cada imagem solicitada é um item. De dezembro a fevereiro, nota-se certa queda no número de pedidos, pelo fato de muitos estarem em férias, entre outros motivos. O volume de trabalho volta ao normal a partir de março.

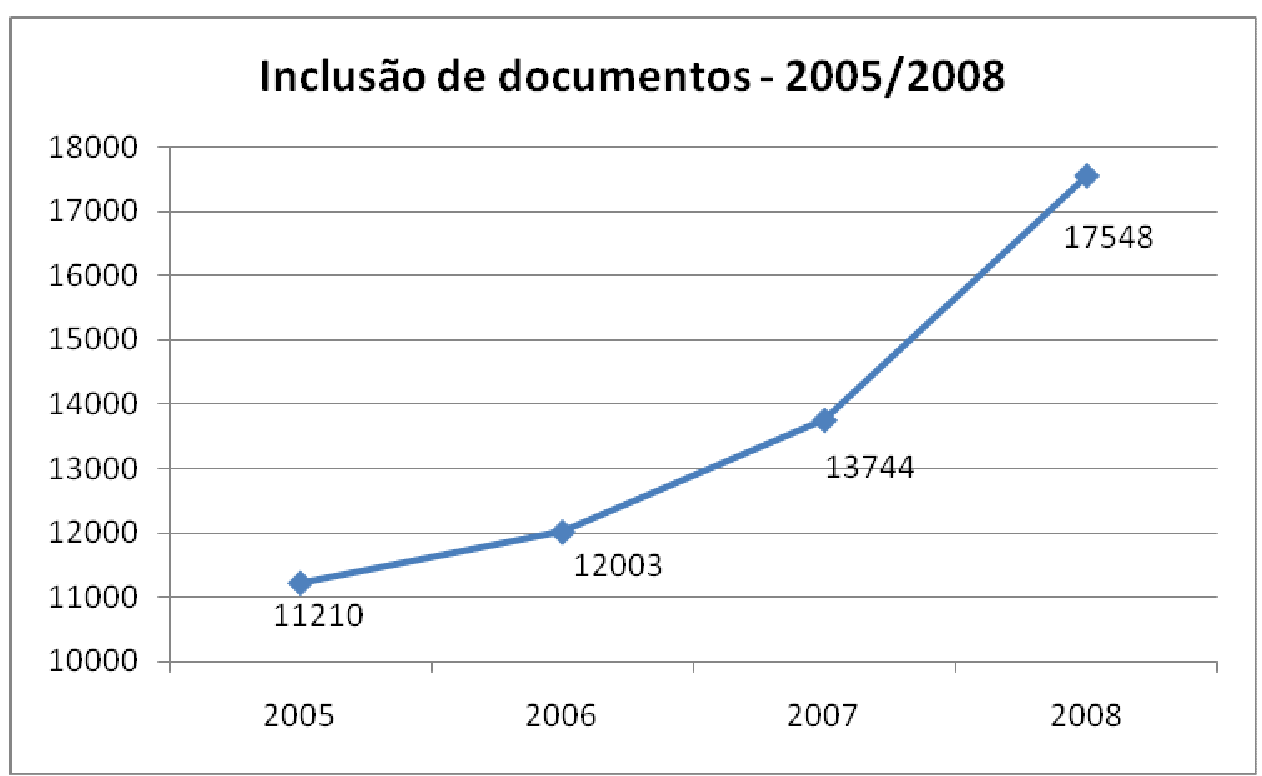

Figura 27: Inclusão de documentos entre 2005 e 2008

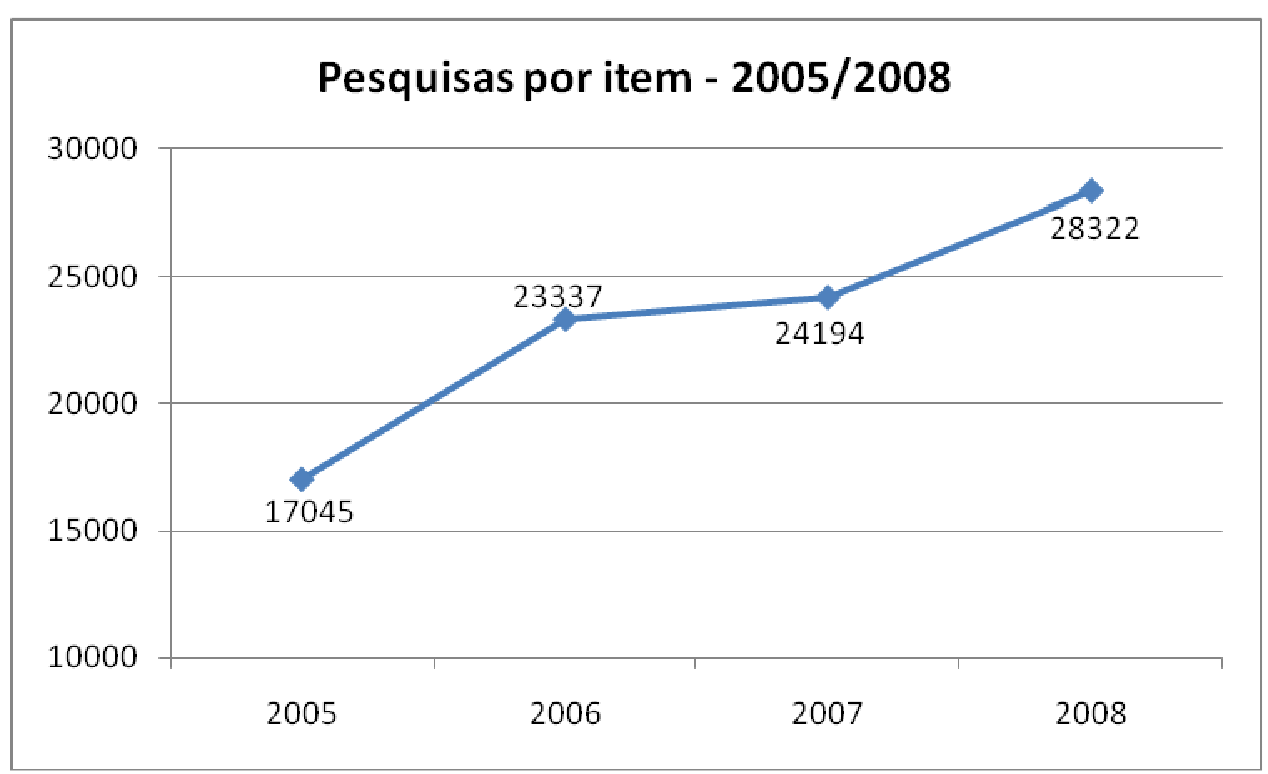

Figura 28: Pesquisas por item entre 2005 e 2008

Os dois últimos gráficos indicam que neste período o Cedoc Brasília apresentou uma demanda crescente de trabalho, apesar de contar com o mesmo número de funcionários e salários defasados. Poucas mudanças têm sido 
alcançadas. No início eram apenas sete funcionários. Hoje são dez (incluindo estagiários), o que foi conquistado com o aumento de demandas. Com as mudanças previstas para os próximos anos, é possível que haja um aumento no quadro. Além de mais funcionários, foram conquistados mais equipamentos, computadores e ampliação do espaço.

Os jornalismos de Rede, Local e Globo News respondem sozinhos por quase 90\% da demanda feita ao Cedoc Brasília. O jornalismo esportivo possui baixa demanda, explicado pelo fato do esporte de Brasília possuir pouca expressividade (salvo raras exceções), além do foco da praça Brasília ser voltado para a cobertura política.

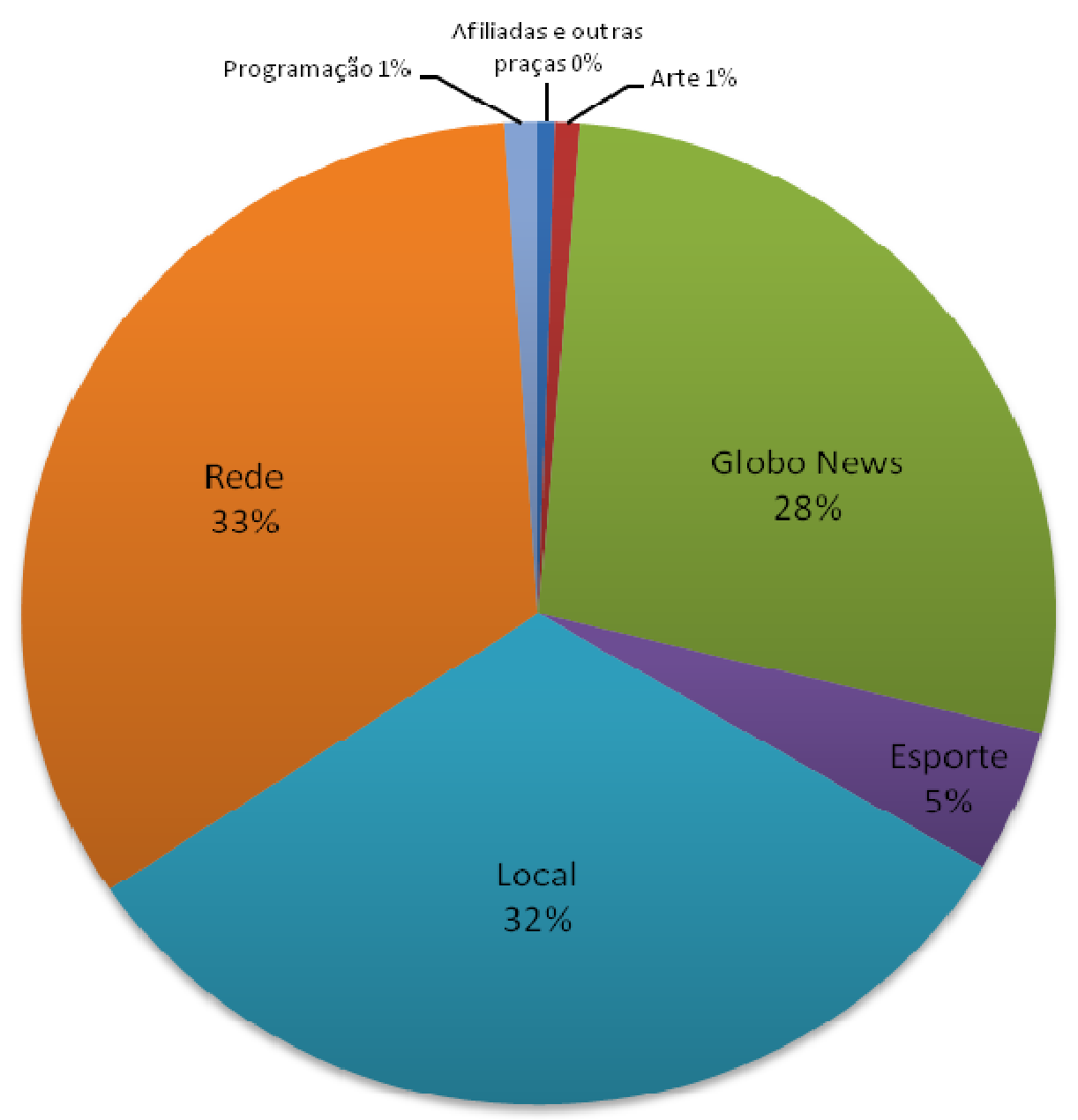

Figura 29: Demanda por área. *Não foram incluídas as seguintes áreas: Comercial, Diretoria Regional, CGCom, Chefia de reportagem, Cinegrafia, Gerop, Tráfego de fitas, Radiobrás/TVE, TV Senado, TV Câmara e Web. 


\section{A VIDEOTECA GLOBAL}

Devido ao fato do Cedoc ser ligado hierarquicamente à CGCom e esta possuir a função de relacionamento com o público externo, foi criada a Videoteca Global, que é o atendimento às instituições educacionais ou associações de classes na suas necessidades. Através da videoteca, são fornecidas fitas de programas (Globo Ciência, por exemplo) para escolas, faculdades e universidades para serem usados em sala de aula, além de ONGs e outras entidades.

Apesar da demanda ser pequena, é necessário certo trabalho para se fazer o atendimento. O projeto ainda está em fase de implantação no Cedoc Brasília, já existindo no Rio de Janeiro, onde conta com uma grande videoteca que funciona como uma biblioteca. Caso a videoteca de Brasília dê certo, será feita uma maior divulgação, pois é interessante para a emissora.

\section{CONCLUSÃo}

O trabalho jornalístico tem se mostrado cada vez mais importante no contexto atual, no qual o fluxo da informação está adquirindo uma velocidade crescente, podendo determinar o ritmo de crescimento de uma sociedade, somado ao processo de globalização em que os meios de comunicação passam por uma fase de integração cada vez mais constante. Assim, é de fundamental importância o trabalho do bibliotecário neste contexto. Apesar da importância do profissional da informação, este ainda carece de reconhecimento, fato que leva ao desconhecimento, desinformação e preconceito por parte da sociedade. Por este motivo, por muito tempo se imaginou a figura do bibliotecário como mero guardador de livros pedindo silêncio aos usuários. Hoje os velhos estereótipos começam a ser derrubados ao se acordar para o enorme valor informacional e a consciência da verdadeira função do bibliotecário.

Ao longo dos últimos anos, os centros de documentação de jornais e redes de televisão foram adquirindo importância vital dentro das organizações, fato que os levou a um constante processo de automação. Essa importância pode ser tanto histórica, quando se refere aos fatos e notícias que são veiculados, ou até mesmo 
organizacional, no que se refere à própria história da empresa à qual pertence o centro de documentação.

O bibliotecário que está inserido nesse meio deve acompanhar a evolução do jornalismo e de sua respectiva produção; não deve desprezar esse campo de trabalho em expansão no qual ainda há carência de profissionais qualificados por ser este um nicho quase inexplorado pela categoria profissional. Ele possui knowhow, ou seja, conhecimentos e técnicas para desempenhar sua função no setor quaternário, ou seja, o da informação.

O trabalho de recuperação de imagens em movimento desenvolvido no Centro de Documentação da TV Globo Brasília demonstra ser de importância fundamental para a emissora. Apesar da demanda crescente de trabalho e recursos financeiros limitados, constata-se que o Cedoc vem conseguindo atender aos objetivos. Trata-se de um trabalho que foi aprimorado ao longo dos anos e hoje serve como modelo para outras emissoras e empresas que lidam com imagens em movimento. O sucesso deste modelo implantado na TV Globo é comprovado pelo fato de, frequentemente, haver pedidos de consultoria para outras emissoras de TV.

O bibliotecário faz parte deste processo, e seu ambiente de trabalho foge das bibliotecas tradicionais. Devido à sua formação generalista e à necessidade de se alcançar um estágio que o qualifique e possibilite lidar com diversos suportes informacionais, pode-se afirmar que ele é o profissional que se encaixa no processo de armazenamento e recuperação de informação audiovisual.

Para que ele alcance tal estágio e se lance no campo do jornalismo e seu ritmo frenético de produção de informação, é preciso que haja uma mudança de mentalidade, que implica num alargamento de horizontes, de fronteiras, abandonando a idéia segundo a qual sua área de atuação se restringe aos limites da biblioteca. É um desafio a ser superado, pois leva ao reconhecimento e à realização profissional. 


\section{REFERÊNCIAS}

AMARAL, Sueli Angélica do. Os multimeios, a biblioteca e o bibliotecário. Revista de Biblioteconomia de Brasília, Brasília, v.15, n.1, p. 45-68, jan/jun. 1987, p. 45.

ANDRADE, Rita Aparecida. O jornalismo na sociedade da informação: a produção e a recepção em jornalismo on-line. Florianópolis: UFSC, 2003. 108p. Dissertação (Mestrado em Engenharia de Produção) - Universidade Federal de santa Catarina.

CAMPELO, Bernadete. Introdução ao controle bibliográfico. 2. ed. Brasília, DF: Briquet de Lemos, 2006.

CONTEÚDOEXPRESSO. Conteúdo expresso. Disponível em:

$<$ http://www.conteudoexpresso.com.br/conteudo/default.asp >. Acesso em: 27 de maio de 2009.

DODEBEI, Vera Lúcia Doyle. Tesauro: linguagem de representação da memória documentária. Niterói, RJ: Intertexto, 2002.

DTV. Entenda a TV digital. Disponível em:

$<$ http://www.dtv.org.br/materias.asp?id=91\&menuid=3>. Acesso em: 6 de abril de 2009.

FIGUEIRA, Nisicler Moreira. Implantação de sistema de documentação em micro / mainframe na Rede Globo. In: Seminário sobre Automação em Bibliotecas e Centros de Documentação (3. : 1989 : Águas de Lindóia). Anais. Águas de Lindóia, 1989.

FIGUEIRA, Nisicler Moreira. O sistema automático de recuperação de materiais especiais do Centro de Documentação da Rede Globo de Televisão (CDRG). In: Congresso Latino-Americano de Biblioteconomia e Documentação, 1. Salvador, 1981. Anais. Salvador, FEBAB, 1981, p. 927-941.

FOLHA ONLINE. Folha online: informática: TV digital chega a Brasília neste mês. Disponível em: <http://www1.folha.uol.com.br/folha/informatica/ult124u544826.shtml >. Acesso em: 6 de abril de 2009.

GONÇALVES, Antônio Cláudio Brasil. Os novos paradigmas da imagem em movimento: em busca de metalinguagens de representação visando a recuperação de conteúdo semântico. Rio de Janeiro: UFRJ, 2003. 306 p. Tese (Doutorado em Ciência da Informação)-IBICT/UFRJ/ECO. Inclui bibliografia.

GONÇALVES, Antônio Cláudio Brasil. A revolução das imagens: uma nova proposta para o telejornalismo na era digital. Rio de Janeiro: Ciência Moderna, 2005.

LANCASTER, F. W. Indexação e resumos: teoria e prática. 2. ed. Brasília, DF: Briquet de Lemos, 2004. 
LE COADIC, Y. A ciência da informação. Brasília, DF: Briquet de Lemos, 1996.

LOBO, Lucia Lahmeyer et al. Base de dados de imagens em movimento brasileiras: Datacinevideo. Rio de janeiro: FCB, 1990. 1 v. Trabalho apresentado no 10. Encontro Nacional de Materiais Especiais e Documento Não-Convencional, Belo Horizonte, 14 a 18 de maio de 1990.

MANINI, Miriam Paula. A dimensão expressiva na indexação de documentos fotográficos. In: Encontro Nacional de Estudos de Imagens, 1., 2007, Londrina. Anais... Londrina: Universidade Estadual de Londrina, 2007.

MIRANDA, Alex Sandro Santos. Ontologias: indexação e recuperação de fotografias... 2007. 130 f. Dissertação (Mestrado em Ciência da Informação) Departamento de Ciência da Informação, Universidade de Brasília.

PALSITE. U-matic PALsite: The U-matic. Disponível em:

$<$ http://umatic.palsite.com/format.html >. Acesso em: 6 de abril de 2009.

PRESIDÊNCIA DA REPÚBLICA. D55782. Disponível em:

<http://www.planalto.gov.br/ccivil 03/Decreto/1950-1969/D55782.htm >. Acesso em: 1 de abril de 2009.

REDE GLOBO. Infra-estrutura. Disponível em:

$<$ http://redeglobo.globo.com/Portal/institucional/foldereletronico/g infra estrutura.htm 1>. Acesso em: 6 de abril de 2009.

RODRIGUES, Anderson; SILVA, Ana Rosa. Base de dados de informações jornalísticas sobre Amazônia: ciência, tecnologia e meio ambiente - BDIJAm: em busca da qualidade. Ciência da Informação, Brasília, v. 36, n. 1, p. 189-196, jan./abr. 2007

ROZADOS, Helen Beatriz Frota. O Jornal e seu Banco de Dados: uma simbiose obrigatória. Ciência da Informação, Jan./Abr. 1997, n.1.

SMIT, Johanna W. A representação da imagem. Informare. Rio de Janeiro, v.2, n. 2, p. 28-36, jul./dez. 1996.

TARGINO, Maria das Graças. Novas tecnologias de comunicação: mitos, ritos ou ditos?. Ciência da Informação, 1995, v. 24, n. 2

VIEWS IMAGENS. Informações técnicas: formatos: 1/9. Disponível em: $<$ http://www.fazendovideo.com.br/vtfor.asp >. Acesso em: 6 de abril de 2009. 


\section{ANEXO A - Questionário enviado para os funcionários do Cedoc}

1- Há quanto tempo trabalha na TVG? E no Cedoc?

2 - Trabalha em outro lugar?

3 - Escolaridade

4 - Tem o costume de usar o Vocabulário Controlado durante as pesquisas?

5 - Se não usa, por quê?

6 - Se usa, como o VC te ajuda?

7 - Quais as dificuldades encontradas durante as pesquisas?

8 - Na sua opinião, o que poderia melhorar no VC? 


\section{ANEXO B - Questionário enviado para a pesquisadora chefe}

1- Há quanto tempo trabalha na TVG? E no Cedoc?

2 - Trabalha em outro lugar?

3 - Qual é sua escolaridade?

4 - Tem o costume de usar o Vocabulário Controlado durante as pesquisas?

5 - Se não usa, por quê?

6 - Se usa, como o VC te ajuda?

7 - Quais as dificuldades encontradas durante as pesquisas?

8 - Na sua opinião, o que poderia melhorar no VC?

9 - Pontos positivos e negativos do sistema

10 - Como surgiu o Cedoc?

11 - Antes da sua criação, como era feito o arquivamento e recuperação?

12 - O Cedoc Brasília não abriga os outros materiais (imagens fixas, recortes, livros...)?

13 - Quais são as principais dificuldades que geram necessidade de mais treinamento do pessoal?

14 - Há dificuldade de se encontrar pessoal especializado?

15 - Poderia citar alguns pedidos estranhos que já apareceram?

16 - Há diferença entre os salários nos Cedocs das praças?

17 - O que está sendo planejado e/ou implantado no Cedoc Brasília a respeito da compra de novos equipamentos?

18 - Com a transmissão digital, o que muda no Cedoc?

19 - Como é a política de concessão de imagens do Cedoc para outras emissoras?

20 - Há imagens cedidas de outras emissoras no Cedoc, exceto as emissoras públicas?

21 - Como se dá a cessão de imagens das TVs públicas (Câmara, Senado, Justiça, etc.)? Há algum tipo de convênio?

22 - O que não pode ser cedido para terceiros?

23 - Como se dá e qual é a função da prestação de contas à CGCom?

24 - Com a apresentação dos números do relatório mensal, tem havido mudanças para atender à demanda crescente de trabalho?

25 - O que tem sido solicitado à CGCom para melhorar o trabalho no Cedoc no que diz respeito a recursos humanos, materiais e financeiros?

26 - Como é o procedimento e quais são os custos para geração de material de outras praças, via malote e via satélite? 
ANEXO C - Exemplos de materiais disponíveis na Videoteca Global

\begin{tabular}{|c|c|c|c|c|}
\hline Data: & Ref.: & Dur.: & título & Sinopse \\
\hline 13.06 .95 & ESP:007 & $46^{\prime}$ & $\begin{array}{l}\text { MEMÓRIA DA } \\
\text { COMUNICAÇÃOO }\end{array}$ & $\begin{array}{l}\text { *QUEDA/MURO/BERLIM; } \\
\text { *URSS/ASCENÇÃO/CAPITALISMO; } \\
\text { *LUTA/DEMOCRACIA/DIREITOS/MU } \\
\text { NDO; } \\
\text { *BRASIL/DITADURA } \\
\text { MILITAR/TORTURAS/ESILADOS/ANI } \\
\text { STIA; } \\
\text { *COLLOR IMPEACHMENT } \\
\text { *HOMEM/LUA/ESPAÇO/ESPLOSÃO/C } \\
\text { HALLAN } \\
\text { GER. }\end{array}$ \\
\hline 14.06 .95 & ESP:008 & $40^{\prime}$ & SEXO & $\begin{array}{l}\text { - Revolução Sexual dos últimos } 30 \text { anos. } \\
\text { - Emancipação da Mulher. } \\
\text { - Epidemia da aids. }\end{array}$ \\
\hline 24.06 .95 & ESP:015 & $46^{\prime}$ & VIOLÊNCIA URBANA & $\begin{array}{l}\text { Neste programa vamos fazer um } \\
\text { retrospecto da } \\
\text { violência no país. } \\
\text { O crime organizado e o medo da } \\
\text { população que se } \\
\text { esconde. O envolvimento de policiais com } \\
\text { o mundo } \\
\text { do crime, tráfico e o consumo de drogas. } \\
\text { As } \\
\text { poderosas armas dos traficantes. } \\
\text { Como os Estados Unidos têm reduzido a } \\
\text { violência. } \\
\text { A precariedade do injusto sistema } \\
\text { carcerário no } \\
\text { Brasil. } \\
\text { Os assassinatos cometidos por filhos, } \\
\text { maridos, } \\
\text { esposas e admiradores. } \\
\text { A guerra da Itália contra a máfia. }\end{array}$ \\
\hline 01.05 .02 & ESP:083 & 73 & $\begin{array}{l}\text { PROFISSÕES(JORNAL } \\
\text { HOJE) }\end{array}$ & $\begin{array}{l}\text { NUTRIÇÃO / RELAÇÕES } \\
\text { INTERNACIONAIS / } \\
\text { ENGENHEIRO AERONÁUTICO / } \\
\text { TURISMO / } \\
\text { DIREITO / FÍSICA / NATUROLOGIA / } \\
\text { NUTRIÇÃO / CIÊNCIAS BIOLÓGICAS } \\
\text { / } \\
\text { MEDICINA VETERINÁRIA / } \\
\text { AVIAÇÃO CIVIL / } \\
\text { ENGENHARIA AMBIENTAL / } \\
\text { METEROLOGIA / } \\
\text { COMPUTAÇÃO / ESTILISMO / } \\
\text { MÚSICA / } \\
\text { ENGEHNARIA DE PESCA / } \\
\text { MATEMÁTICA } \\
\text { INDUSTRIAL / ATOR / CHEFE DE } \\
\text { COZINHA / } \\
\text { BOMBEIRO }\end{array}$ \\
\hline
\end{tabular}




\section{ANEXO D - FOTOS}

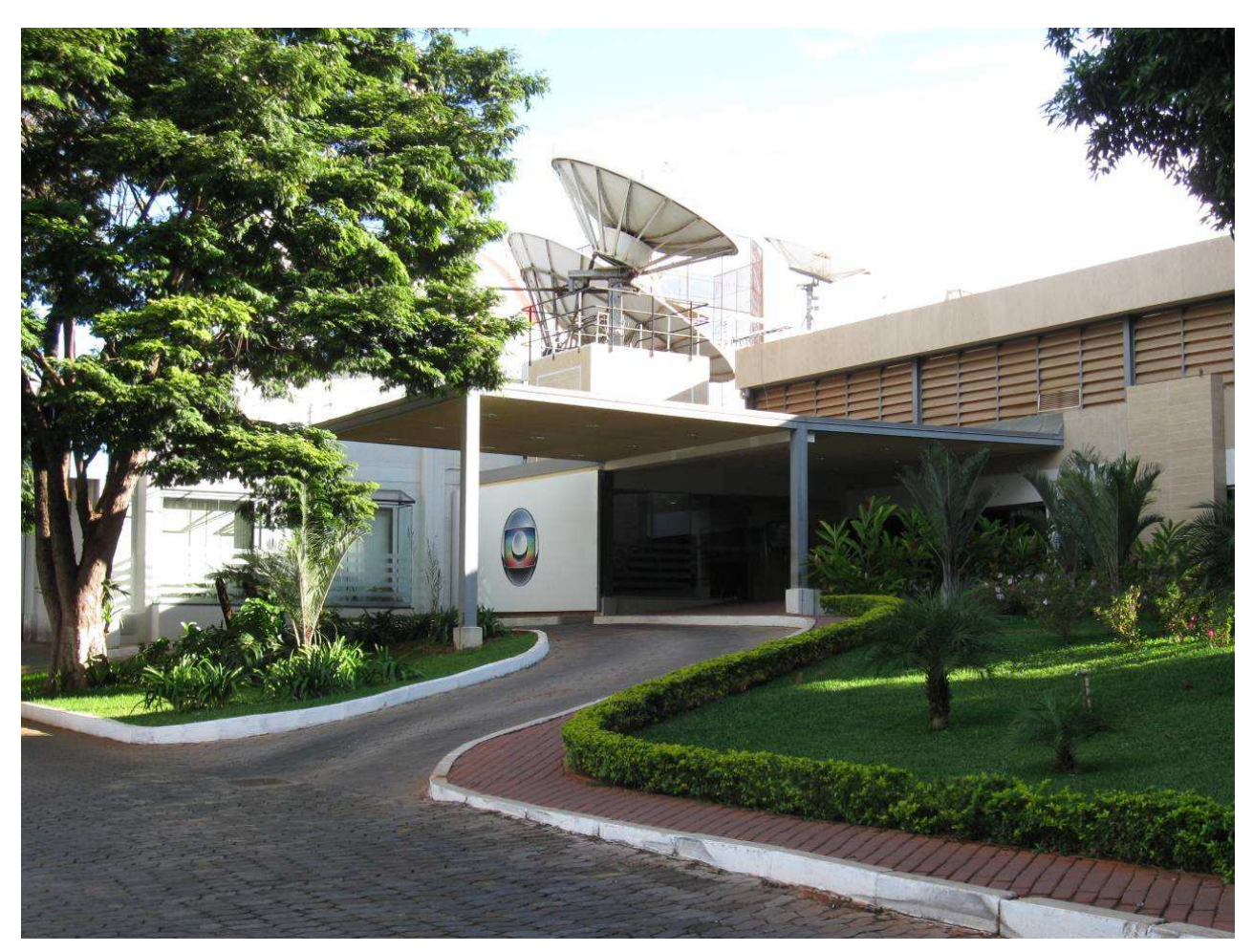

Portaria da TV Globo Brasília

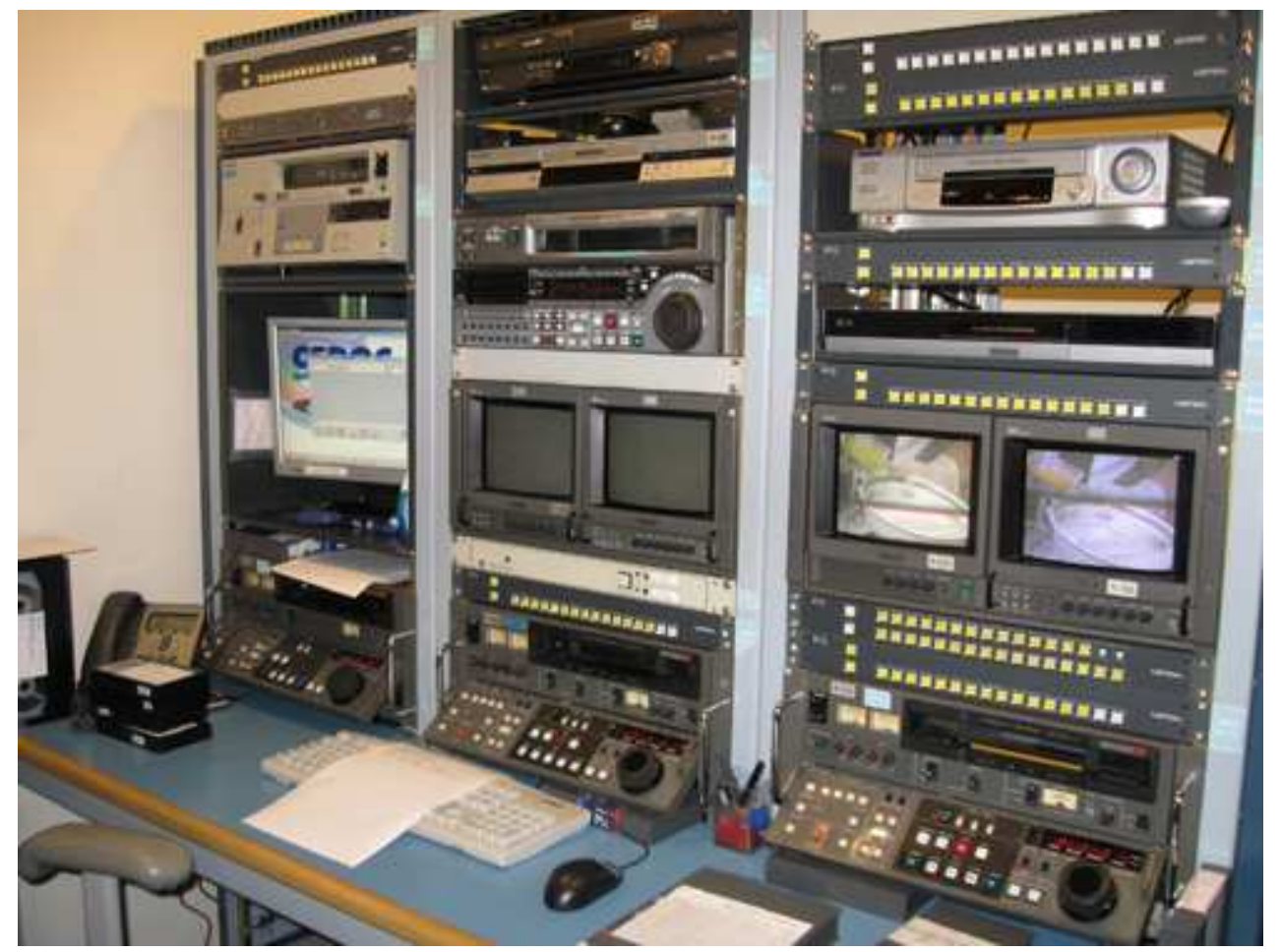

Ilha de edição e cópia de vídeos - Cedoc Brasília 